\title{
Ho 13032
}

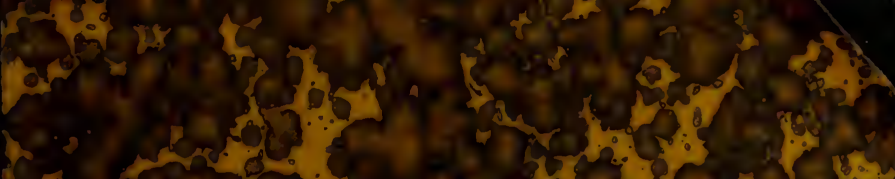

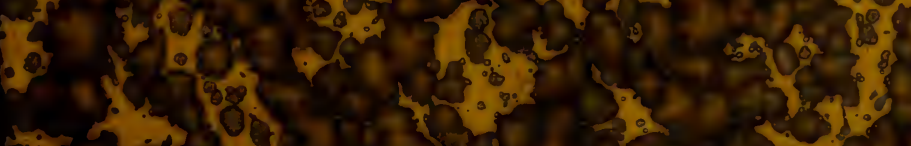

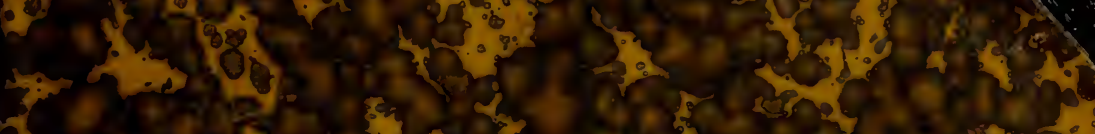

th 40 .

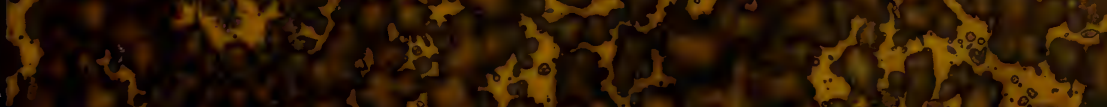
4. 0 rotion

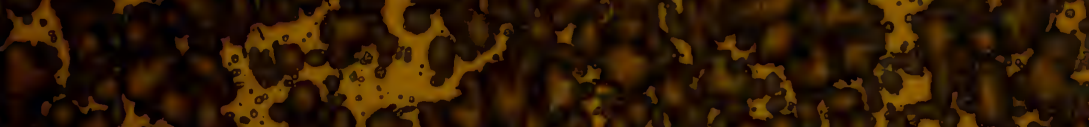

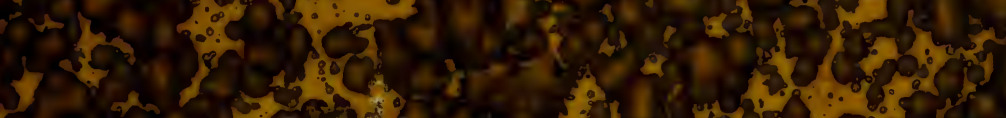
H. 5004 $3 x^{\circ}$.

If

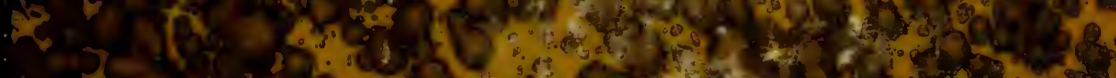

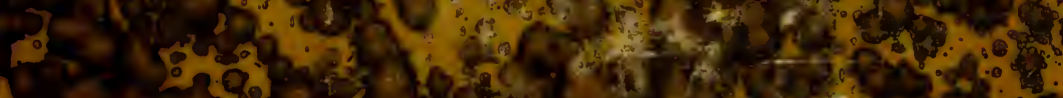

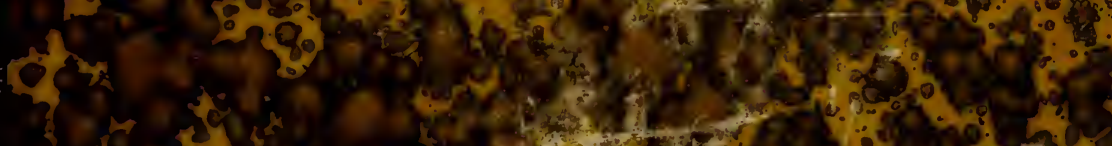

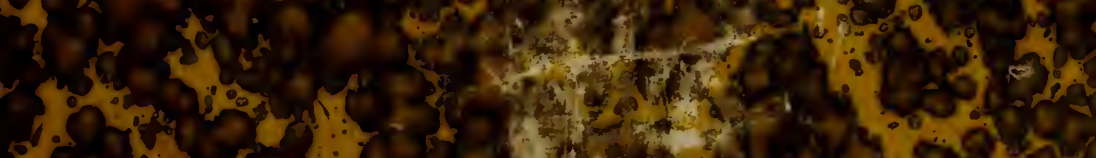

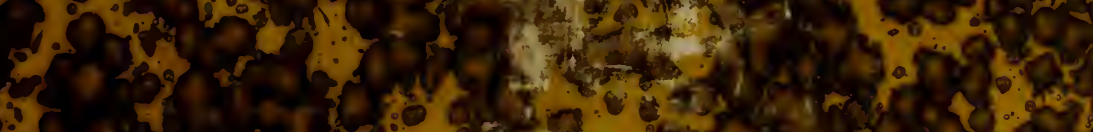

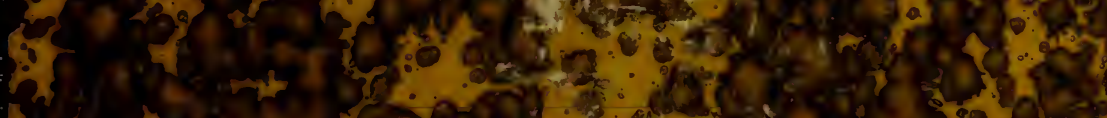
d.

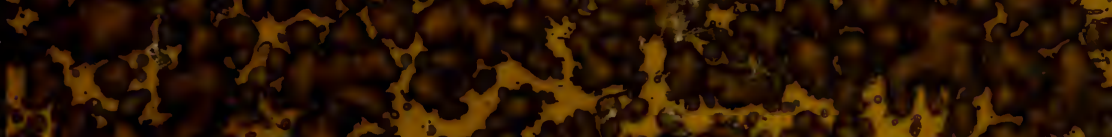

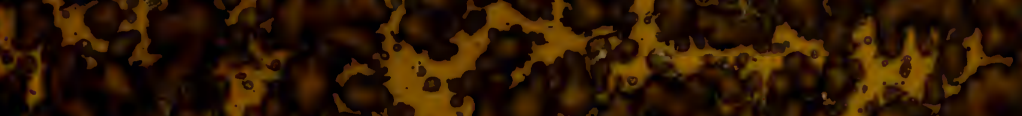

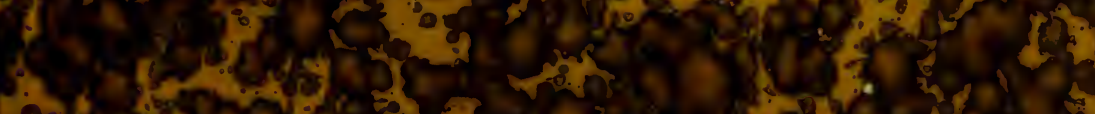
or

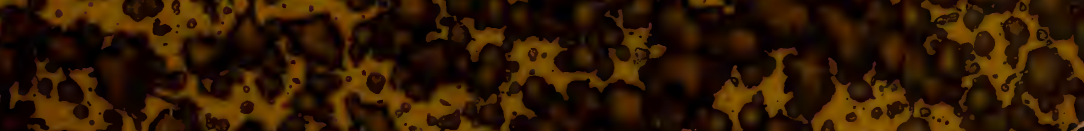

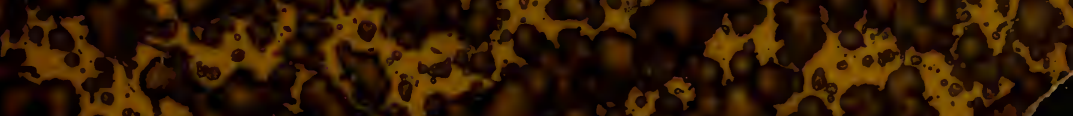

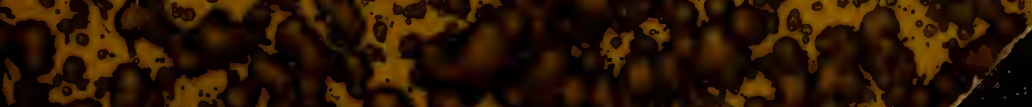

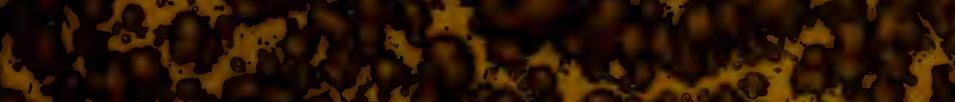
$3+0$ arom

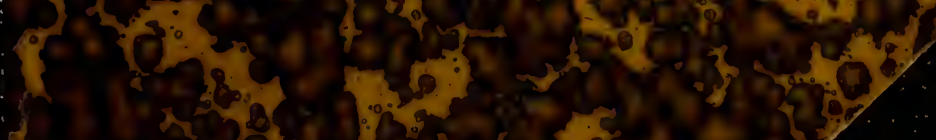



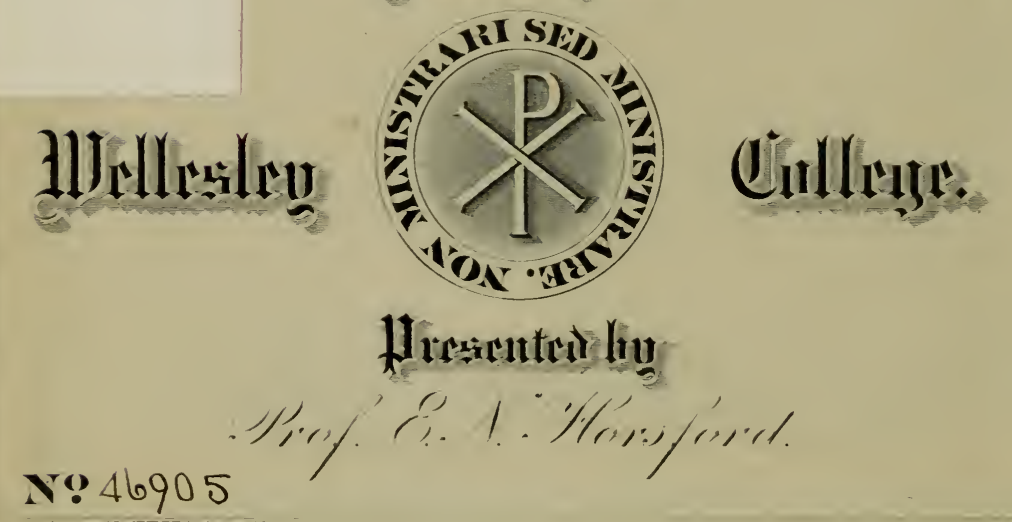

Cfilintu ut

firctutuling

N946905 


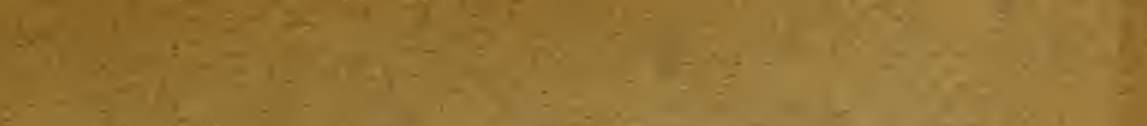

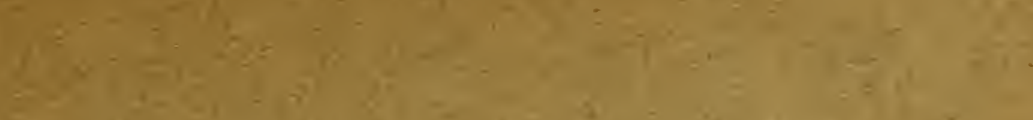

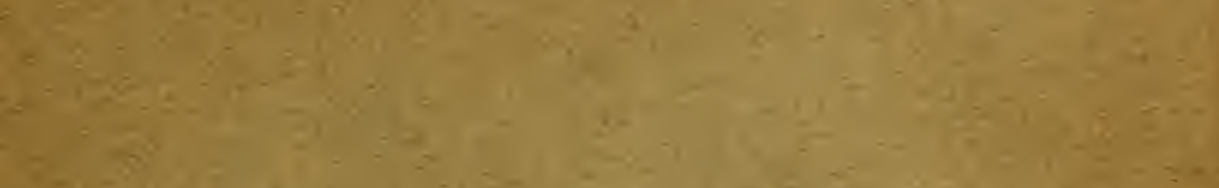

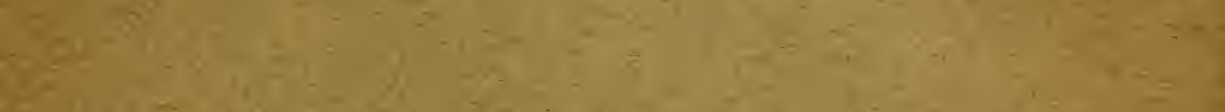

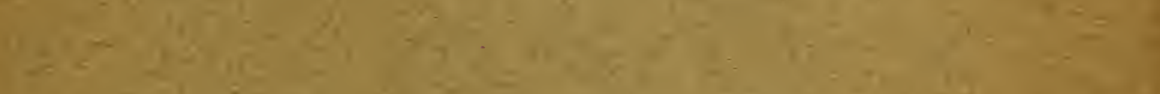

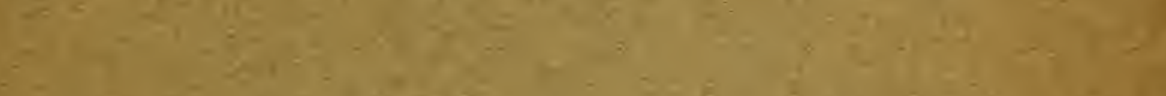

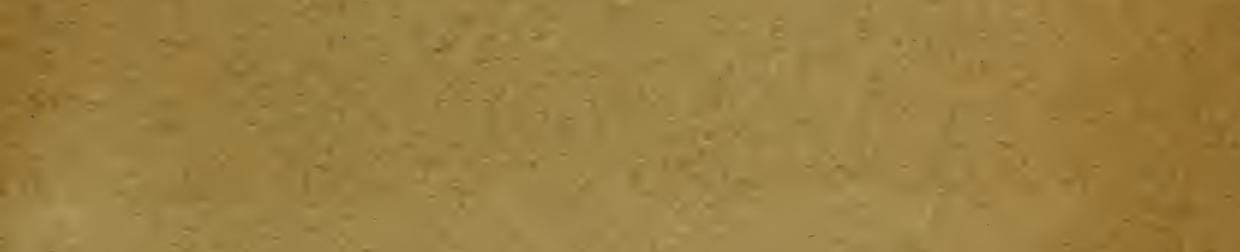

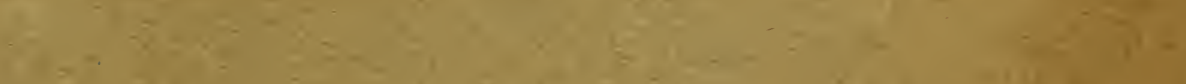

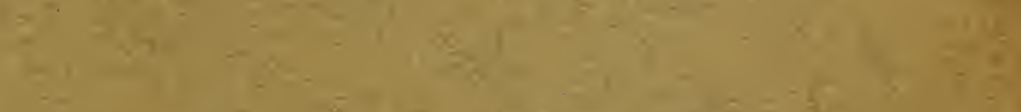

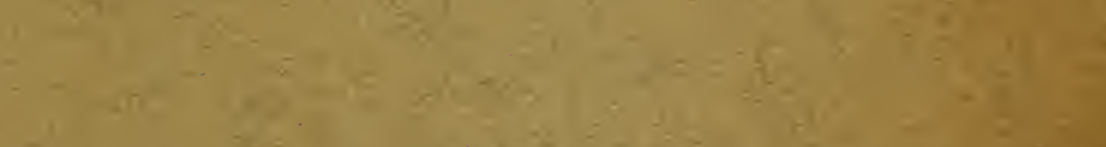

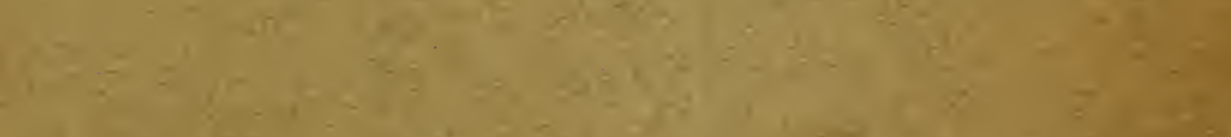

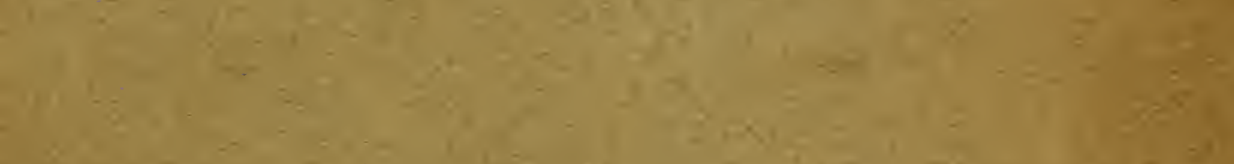

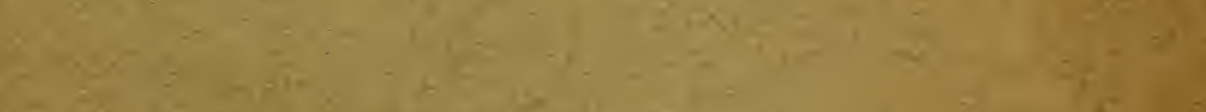

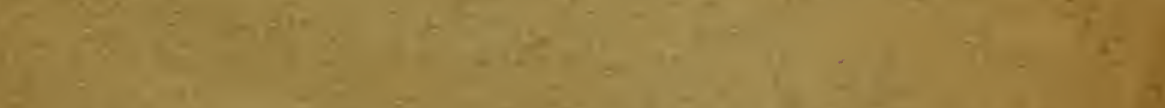

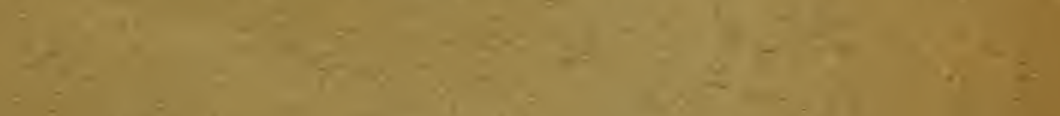

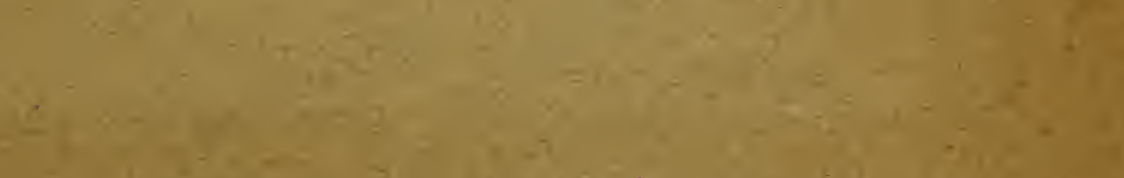
7 $\frac{1}{2}$ (1)

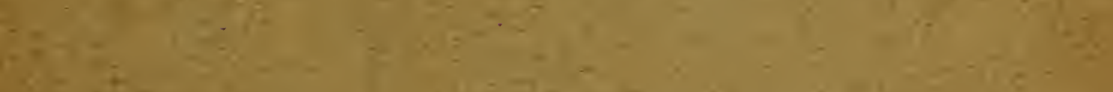
(1)

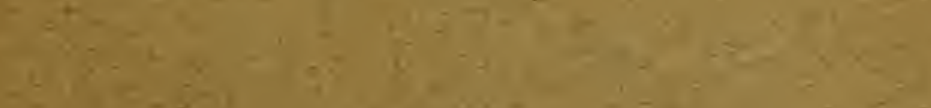

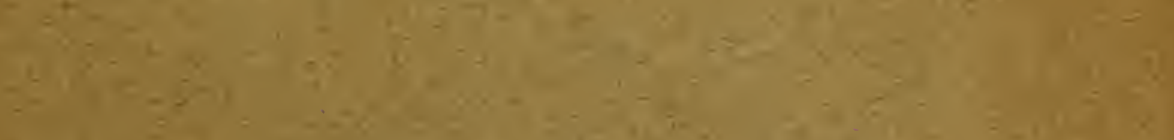

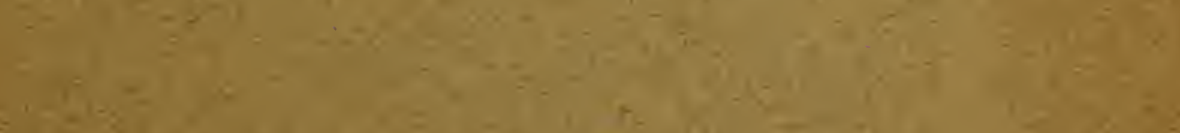

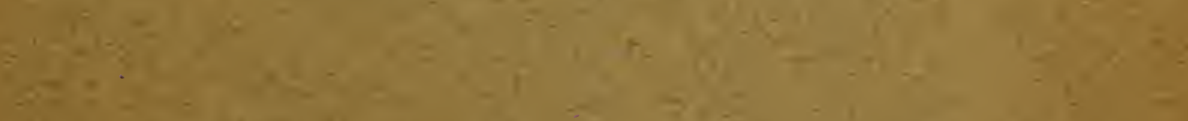

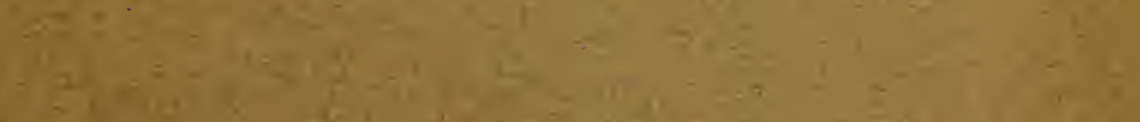

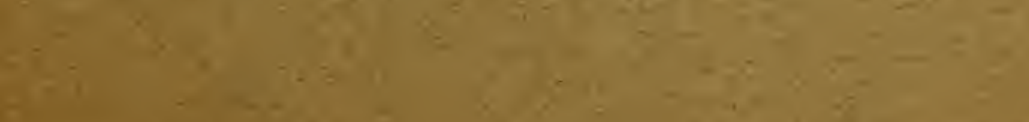





\section{EMOIRS}

OF THE

\section{TORREY BOTANICAL CLUB.}

Vol. III.

No. 3 .

On the Collections of Mr. Miguel Bang in Bolivia.

By Henry H. Rusby.

\section{Preliminary Remarks.}

The study of the Bolivian flora, as represented in the collections made by myself in the years 1885 and 1886 , the enumeration of which is still proceeding in the pages of the Bulletis, proved so interesting to Dr. Britton and myself that we became very desirous of having the collections continued. An opportunity to gratify this desire was found in I889, when Mr. Miguel Bang consented to carry on the work which I had begun. Mr. Bang is the son of a Danish clergyman, educated in gardening at Kew, who went to Bolivia somewhere about the year 1883 , for the purpose of collecting and sending to England living orchids. The enterprise proving unsuccessful, Mr. Bang engaged in other pursuits in the vicinity of $\mathrm{La} \mathrm{Paz}$, where I met him in $\mathrm{I} 885$, and formed the acquaintance from which the present arrangement has resulted. Since Mr. Bang began collecting, the work has been pushed as steadily as circumstances would permit. It was hoped that the proceeds from the sale of specimens would more than pay the expenses of collection, so that Mr. Bang might derive more or less profit from the enterprise; but unfortunately such has not been the case. In spite of every effort and economy, I have found it necessary to supply a considerable deficiency, while Mr. Bang has received nothing beyond his expenses. Indeed, owing to a lack of ready funds, it has not been possible to fully utilize the time in collecting. It is very desirable that additional subscribers for the sets 
may be secured. The annual collections range from 500 to $\mathrm{I}, 000$ specimens per set, and are for sale at \$IO per hundred.

For the benefit of botanists who may have occasion to consult these specimens, the following list of subscribers is appended. The names stand in the order in which the subscriptions were received, the earlier sets being the more complete. In consideration of facilities for study afforded by the Kew and Columbia herbaria, those institutions have been presented with their sets.

Set No. I. Columbia College, New York City.

" 2. Capt. John Donnell Smith, Baltimore, Md.

“ 3. Mr. Wm. M. Canby, Wilmington, Del. (The Canby Herbarium has now become the property of the New York College of Pharmacy.)

" 4. The Royal Botanical Museum, Berlin.

" 5. The Philadelphia Academy of Sciences, Philadelphia, Pa.

“ 6. The United States Department of Agriculture, Washington, D. C.

" 7. The Gray Herbarium of Harvard College, Cambridge, Mass.

“ 8. The Missouri Botanical Garden, St. Louis, Mo.

" 9. The University of California, Berkeley, Cal.

“ Io. The Herbarium of the Royal Botanical Garden, Kew.

" II. The Herbarium of the British Museum.

" I2. Wellesley College, Wellesley, Mass.

" I 3. The Boissier Herbarium, Chambesy, Switzerland.

"I4. The Herbarium of the Royal Botanical Garden, Edinburgh.

“ I 5. The Breslau Botanical Garden.

“ I6. The Imperial Academy of Science, St. Petersburg.

" I7. The Imperial Natural History Museum, Vienna.

“ I8. Mr. J. C. Melville, Manchester, England.

“ 19. Messrs. Parke, Daris \& Co., Detroit, Michigan.

“ 20. Rev. J. H. Wibbe, Schenectady, New York.

The Cryptogams are taken by Prof. L. M. Underwood, Greencastle, Ind.

The Glumacex are taken by Prof. IV. J. Beal, Agricultural College, Michigan. 
The woody plants are taken by Prof. C. S. Sargent, Brookline, Mass.

The collections will be enumerated in fascicles of I,000 numbers. When necessary, as in the present instance, the fascicles will be divided into two parts, the first part including the Compositæ. A few doubtful or difficult species may be looked for in an appendix to each fascicle, in which place it will also probably be necessary to publish some corrections.

I have found invaluable the kind assistance of Dr. Britton, at every stage of the work, but particularly in having compared the specimens at the Kew herbarium, and indicated those which could not be matched there. In very few instances have $I$ found it possible to find published descriptions of such species.

I am also indebted to Messrs. Bennett and Chodat, for their judgment upon the Polygaleæ, to Herr Urban who has reported upon the Loasaceæ, and especially to M. Cogniaux for having given me the benefit of his remarkable knowledge of the Melastomaceæ.

\section{RANUNCULACEE.}

Clematis Cochabambensis, sp. $\mathrm{n}$. Climbing, shrubby, the stem sharply angled and downy, the younger portions tomentose; leaves 4 or $5 \mathrm{~cm}$. long, on petioles $3 \mathrm{~cm}$. long, the latter terete, the base dilated and channelled, divaricate or reflexed and cirrhose; primary divisions about 3 pairs, the longest petiolules nearly I $\mathrm{cm}$. long; primary divisions about thrice divided, of the ultimate divisions, the lateral 2-the terminal 3-lobed, with cuneate base, the lobes inequilaterally lance-oblong, acutish, thick and stiff, canescent, I-2 mm. long and scarcely I $\mathrm{mm}$. broad, rather densely massed; flowers not seen; panicles in fruit dense, several or perhaps many flowered, the flowers solitary in the upper axils; primary bracts similar to the leaves, the bracteoles opposite, lance-awl-shaped, deciduous; fruiting pedicels $2 \mathrm{~cm}$. long, slightly angled, tomentulose; akenes about 25 , lance-oval, sessile or on a slightly produced base, reddish-brown, glabrescent, the fully developed ones rather abruptly contracted into a stout, naked beak of the same color as the body, and shorter, the latter $3-4 \mathrm{~mm}$. long; the densely plumose portion of the style nearly $3 \mathrm{~cm}$. long, yellowish-white. Vicinity of Cochabamba, I 89 I (759).

Clematis Bangir, sp. n. Shrubby, climbing, glabrous except the inflorescence and fruit, the green or purplish stems strongly 
(about 8) channelled, the internodes $10-15 \mathrm{~cm}$. long; leaves somewhat disposed to be erect, both petioles and petiolules strongly cirrhose, the former channeled throughout and gradually dilated downward, 7-10 $\mathrm{cm}$. long, slender; divisions of leaf apparently 5, the lower pair distant, all much alike, on long slender petiolules, lanceolate with rounded or slightly narrowed base, regularly tapering to an acute point, $7-10 \mathrm{~cm}$. long by $\mathrm{I}-2 \mathrm{~cm}$. broad, some with a strong and sharp lobe upon one side, coriaceous with 2-4 sharp and strong parallel veins from near the base, prominently but sparingly reticulate; peduncles in flower about $5 \mathrm{~cm}$. long, ribbed, the panicle compound, its few divisions each 5-8-flowered, the branches cinereous; lower bracts similar to the leaf divisions but narrower, the bracteoles elongated, strap-shaped and, like the pedicels and calyx, densely white hairy, or the bracteoles tawny; sepals 4, oblong, obtuse, tawny with narrow white margins, about $\mathrm{I} \mathrm{cm}$. long by $4 \mathrm{~mm}$. broad, somewhat leathery, exceeding the numerous stout stamens; akenes numerous, light brown, with thick, lighter colored margins, villous, oblanceolate, about 5 $\mathrm{mm}$. long, the base narrowed, the apex abruptly contracted into the style, which is plumose, but not densely so, throughout, 5-8 cm. long, very slender.

Vicinity of Cochabamba. I89 I (988).

Thalictrum podocarpum, H. B. K. Nov. Gen. v. 38. Songo, Nov., I89I (893). Vicinity of Cochabamba, I89 I (758). = Rusby $5 \mathrm{OI}$ and 502 .

Ramunculus pilosus, H. B. K. Nov. Gen. v. 45. Vicinity of La Paz, I0,000 feet, I890 (147). = Rusby 5 IO.

Ramunculus repens, L. Sp. Pl. 779. Flowers double. Yungas, I890, escaped (190). = Mandon 878. Dr. Britton informs me that all the Andean specimens in the Kew herbarium are double flowered.

\section{ANONACEÆ.}

Guatteria pogonopus, Mart. Fl. Bras. xiii. i. 34. Yungas, I 890. $(583)=$ Rusby 1252.

BERBERIDEÆ.

Berberis Boliviana, Lechl. Berb. Amer. Austr., 2 I (?). Songo, Nov., I890. (863) = Mandon 864. Judging from the description in Chlor. And. 294, Mr. Bang's plant differs in the size and number of leaves, the number of flowers, and their disposition. 
Berberis rectinervia, sp. n. Fruticose, the stems virgate, leafy, nigrescent, unarmed; leaves 5-6, fascicled, persistent until after the appearance of an equal number of new ones, $8-15 \mathrm{~mm}$. long, 3-5 $\mathrm{mm}$. broad, oblanceolate to spatulate, tapering to the base, very thick, smooth, shining above, tipped with a short reddishbrown spine, entire, or a few with I or 2 spinescent teeth near the apex, underneath with several strong veins nearly parallel with the strong midrib; flowers solitary or $2-3$ together, very short pedicelled, nearly or quite erect.

Songo, Nov., I891, (857). Also collected by Pearce at La Banca at an altitude of 10,000 or I $2,000 \mathrm{ft}$., fide Britton.

PAPAVERACE $\AA$.

Argemone Mexicana, L. Sp. Pl. 508. Vicinity of Cochabamba, I 89 I (943).

Bocconia frutescens, L. Sp. Pl. 505. Yungas, I890 (44I).

CRUCIFER $\mathrm{E}$.

Roripa Nasturtium (L.) Scopoli. (Nasturtium officinale, R. Br.) Vicinity of La Paz, I0,000 ft., I 889 (65).

Cardamine ovata, Benth., var. corymbosa, Britton, Bull. Torr. Bot. Club, xvi. I6. Yungas, I 890 (227). = Rusby 1206 and Spruce 5378.

Sisymbrium officinale (L.) Scopoli. Vicinity of Cochabamba, I89 I (888). A very scabrous form.

Sisymbrium myriophyllum, H. B. K. in D. C. Syst. ii. 477. Talca Chugiaguilla, Apr. I 890 (8 I 5).=Rusby 205.

Sisymbrium Pazensis, sp. n. Apparently biennial, grayish-hispid throughout, stem erect, 3-6 dm. high, stout, simple, purplish ; leaves few, the radical not present; lowest cauline $3-4 \mathrm{~cm}$. long, by $1.2 \mathrm{~cm}$. broad, oblong-spatulate, obtuse, contracted into a petiole-like base, thick, with prominent midrib, both sides gray-hispid, coarsely few toothed; the upper similar, fewer toothed or entire, closely sessile; inflorescence of several erect crowded racemes, forming a narrowly contracted, nearly naked panicle, at length $20 \mathrm{~cm}$. long; flowers 4-5 $\mathrm{mm}$. long, about equalling the stout pedicel; calyx purple, two-thirds as long as the white (purplish?) petals; pods oblong-linear, $2 \mathrm{~cm}$. long by $2 \mathrm{~mm}$. broad, bright purple, seeds in 2 rows, very small.

Vicinity of La Paz, I0,000 ft., I 890 ( I 72 ).

Lepidium bipinnatifidum, Desv. Journ. Bot. iii. I65. Vicinity of La Paz, I0,000 ft., I 889 (23).=Rusby I 201 and I 202. 
Lepidium Chichicara, Desv. Journ. Bot. iii. 165. Vicinity of La Paz, I0,000 ft., 1889 (15).=Rusby 1203.

\section{CAPPARIDE $Æ$.}

Cleome spinosa, L. Sp. Pl. Ed. 2, 939 . Yungas, I 890 (485).

Cleome gigantea, L. Mant. 430. Yungas, $1890(645$ and 645 a, as

to specimens having the pedicels nearly smooth.

Cleome. Yungas, 1890 ( 645 a, as to specimens consisting of flowers only, the pedicels glandular-hairy).=Rusby 736 .

\section{VIOLACEÆ.}

Viola scandens, Willd. in H. B. K. Nov. Gen. v. 37I. Yungas, I 890 (704). A smaller and less luxuriant form than Rusby's

844 and 845 . Also vicinity of Cochabamba, I 89I (882).

Viola veronicafolia, Pl. and Lind. Ann. Sci. Nat. (IV.) xvii. I2I.

Yungas, I 890 (323). = Rusby 842.

Viola micranthella, Wedd. Talca Chugiaguilla, April, I 890 (8I I).

$=$ Mandon 942 .

Calceolaria (Ionidium) Bangil, sp. n. Herbaceous, 3-6 dm. high, the stems terete, erect-branching, minutely puberulent; leaves membranaceous, alternate or a few of the lower subopposite, $2.5-5 \mathrm{~cm}$. long, oblong to rhombic-oval, obtuse, acuminate, with a short and slender petiole, either bluntly or incisely dentate, smooth on both sides, paler below; stipules whitish, subulate, finely attenuate, $2 \mathrm{~mm}$. long; flowers axillary, on narrowly filiform, naked peduncles, two-thirds as long as the leaves; flowers $3-4 \mathrm{~mm}$. long; fruit $3-4 \mathrm{~mm}$. long, twice the length of the calyx, globose, ribbed, tipped with a short, stout, whitish point.

Yungas, 1890 (553).

Leonia glycycarpa, R. \& P. Fl. Per. ii. 69, t. 222. Songo, Nov., $1890(846) .=$ Rusby 2647.

\section{BIXINEÆ.}

Bixa Orellana, L. Sp. Pl. 5 I2. Yungas, I890 (214 and 606).

\section{POLYGALEÆ.}

Polygala filiformis, St. Hil. Fl. Bras. Mer. ii. I. Yungas, I 890 (415).

Polygala Boliviensis, A. W. Bennett, var. albiflora, Chodat. Vic. Cochabamba, I 89I (947).

Monnina cestrifolia, H. B. K. Nov. Gen. v. 419. Yungas, I890 (698). 
Monnina parviftora, H. B. K. Nov. Gen. v. 4I9. Yungas, I890 (292).

Krameria triandra, R. \& P. Fl. Per. i. 6I. Vic. La Paz, I0,000 ft., I 889 ( I I9).

\section{VOCHYSIACEÆ.}

Vochysia Boliviana, sp. n. Branchlets blackish, quadrangular with rounded angles, strongly sulcate, flattened just below the nodes, the youngest pubescent, the internodes $4-6 \mathrm{~cm}$. long by nearly I $\mathrm{cm}$. broad; stipules subulate, coriaceous thickened at base, I $\mathrm{cm}$. long; petioles very stout, I.5-2.5 cm. long; leaves about $20 \mathrm{~cm}$. long by $8 \mathrm{~cm}$. broad, oblong-elliptical, the base rounded to sub-cordate, the apex abruptly produced into a short, stout, tapering but obtuse point, very thick and rigid, above smooth and shining with sulcate midrib, below grayishgreen, finely and closely appressed-tomentose, the midrib strong; primary branches of midrib 20 or more pairs, slender but prominent, parallel, slightly curved, arching together very near the entire margin; racemes cylindrical, $12-15 \mathrm{~cm}$. long by $4-5 \mathrm{~cm}$. broad, rather loose; peduncles mostly 2 -flowered, 4-6 $\mathrm{mm}$. long, the pedicels $5-8 \mathrm{~mm}$. long; bud I $2 \mathrm{~mm}$. long; spur Io $\mathrm{mm}$. long, terete, slightly tapering, blunt, abruptly curved near the end, the long sepal reflexed after flowering; pubescent middle petal and pubescent stamen, IO-I $2 \mathrm{~mm}$. long, the lateral petals $8 \mathrm{~mm}$. long; filament not exceeding one-fifth the total stamen length; style cylindrical, slightly thickened above, glabrous; fruit unknown.

Songo, Nov., I 890 (826). According to description of $V$. splendens, Spruce, in Fl. Bras., this is very near that species, and intermediate between it and $V$. vismicefolia, but the sub-cordate leaves and proportions and dimensions of the floral parts appear to distinguish it.

CARYOPHYLLEÆ.

Cerastium arvense, L. Sp. Pl. 438. Capi, March, I890 (77.5). = Rusby I I94.

Alsine media, L. Sp. Pl. 272. (Stellaria media, Smith.) Yungas, I 890 (442).

Arenaria lamuginosa (Mx.) Rohrb. in Mart. Fl. Bras. Caryophyll. 274. Yungas I 890 (240). = Rusby II 87 and I I 88.

Drymaria cordata (L.) Willd. in R. \& S. Syst. Veg. v. 406. Yungas, I 890 (233). = Rusby I 82.

Tissa villosa (Pers.) Britton, Bull. Torr. Bot. Club, xvi. 62. Talca Chugiaguilla, Apr., I 890 (8I4).= Rusby II 8I. 
Tissa marina (L.) Britton, Bull, Torr. Bot. Club, xvi. I26. Yungas, I 890 (162).

PORTULACE E.

Portulaca pilosa, L. Sp. Pl. 445. Vicinity of La Paz, Io,000 feet, I 889 (57).

Talimum patens (L.) Willd. Sp. Pl. ii. 864. Yungas, I 890 (282). Calandrinia caulescens, H. B. K. Nov. Gen. vi. 78. Yungas, I890 (283).

Calandrinia acaulis, H. B. K. Nov. Gen. vi. 78. Songo, Nov., I 890 (9I 7).

HYPERICINEA.

Hypericum thesiifolium, H. B. K. Nov. Gen. vi. I92. Talca Chugiaguilla, Apr., I 890 (810). = Rusby I 196 and I 389.

Caopia (Vismia) glabra (R. \& P.) Kuntze, Rev. Gen. Pl. 59. Yungas, I 890 (595 and 62I). Songo, Nov., 1890. (835). 595 was distributed as "Monorobia."

Caopia (Vismia) tomentosa (R. \& P.) Kuntze, Rev. Gen. Pl. 59 (?) Yungas, I 890 (683).

Differs materially from the specimens and description of this species, but placed here provisionally.

\section{GUTTIFER Æ.}

Tavomita umbellata, Benth. in Mart. Fl. Bras. Guttif. 448. Yungas, I 890 (419).

\section{TERNSTRCEIACE $\AA$.}

Marcgraavia peduncularis, Pœpp. in Herb. Kew, fide Britton. Glabrous, stems gray; petioles stout, $0.5-1 \mathrm{~cm}$. long; leaves 6-9 $\mathrm{cm}$. long, 4-6 cm. broad, obovate, the base obtuse or acutish, the apex rounded and often notched, margin entire, somewhat revolute, very thick and coriaceous, light green and somewhat shining above, below of a rich brown (in dried specimens), and exhibiting, parallel with each margin and distant therefrom more than one-third of the distance to the midrib, a row of about a dozen large whitish elevated and punctured glands; corymb terminal, short peduncled; pedicels not, or slightly curved, about $4 \mathrm{~cm}$. long, stout aud somewhat thickened upward, finely striate; flowers globose-obovoid, 8 $\mathrm{mm}$. long and broad, the sepals of a rich brown color, semicircular, with light colored crisped or lacerate margins; bracts sub-pedicelled by a very broad base, I $2-20 \mathrm{~mm}$. long, hastate, the expanded basal portions about I $\mathrm{cm}$. broad, the saccate portion oblanceolate, obtuse, 3-6 cm. long.

Yungas, I 890 (390). 
Mokofua Brasilicnsis (Camb.) Kuntze, Rev. Gen. Pl. 63. (Temstramia Brasiliensis, Camb., in St. Hil. Fl. Bras. Merid. i. 298.) Songo, Nov., I 890 (837). Leaves narrower and base more cuneate than in Rusby's No. 486.

Mokofua congestiflora, (Tr. \& Pl.) Kuntze, Rev. Gen. Pl. 63. (Temstramia congestiflora, Tr. \& Pl., Ann. Sci. Nat., Ser. 4, xviii. 259.) Songo, Nov., I 890 (838). = Rusby 6 I 7 .

Erotium Yungasium (Tul.). (Freziera Iungasia, Tul. Ann. Sci. - Nat. (III.) viii. 333. Yungas, I890 (386).

ERotium subintegrifolium, sp. n. Branches elongated, sub-flexuous, reddish-brown, very sparingly hairy, roughish with the prominent lenticels, the internodes marked on either side by a bright red ridge continuous with the margin of the petiole next above; petioles 25-30 $\mathrm{mm}$. long, somewhat more hairy than the branches, strongly margined; leaves $\mathrm{I} 2-\mathrm{I} 6 \mathrm{~cm}$. long, 7-IO cm. broad, ovate-oblong, base rounded, apex very shortly and bluntly acuminate, the margin almost entire and faintly revolute, thickened, rigid, when very young hairy below, but soon perfectly glabrous, the midrib and veins very prominent underneath, the latter numerous and parallel, the alternate ones much fainter; fascicles crowded, 5 to 7 -flowered, the pedicels very ehort; flowers nearly I $\mathrm{cm}$. long, hermaphrodite; bracts 2 , half the length of the sepals, which are cartilaginous, perfectly glabrous, minutely ciliate, oval or nearly reniform; petals similar, ovate, nearly twice the length of the sepals; stamens half the length of the petals, the slender filaments one-half longer than the lance-oblong anthers; pistil about as long as the stamens; ovary 3- or imperfectly 4-celled, twice as long as the style. Stigma oblong.

Yungas, I 890 (496).

Saurauja pariiflora, Tr. \& Pl. Ann. Sci. Nat. (IV.) xviii. 268. Yungas, I 890 (387).=Rusby 483 .

Hemocharis semiserrata (Camb.) Mart. et Zucc. Nov. Gen. i. IO7,

t. 66. (Laplacea semiserrata, Camb. in St. Hil. Fl. Bras. Mer.

i. 300.) Yungas, I 890 (385). =Rusby 485 .

\section{MALVACE $Æ$.}

Malveopsis Rusbir (Britton). (Malvastrum Rusbyi, Britton, Bull. Torr. Bot: Club, xvi. 64.) Vicinity of La Paz, I0,000 ft., I 889 (39).

Malveopsis multicaulis (Britton). (Malvastrum multicaule, Britton, Bull. Torr. Bot. Club, xvi. I 53.) Vic. La Paz, I0,00o ft.(I 26). 
Malveopsis —, apparently, but more material needed. Vic. Cochabamba, I891 (953).

Sida rhombifolia, L. Sp. Pl. 684. Vic. La Paz, Iо,000 ft., I 890. (206). Yungas, I 890 (209).

Sida urens, L. Sp. Pl. Ed. 2, 963 . Yungas, I 890 (652).

Sida carpinifolia, L. f. Suppl. 307. Vic. La Paz, I0,000 ft., I 890 (476).

Sida ciliaris, L. Sp. Pl. Ed. 2, 96 I. Vic. Cochabamba, I89 (934).

Wissadula andina, Britton, Bull. Torr. Bot. Club, xvi, I53. Capi, March, I 890 (768).

Abutilon syliaticum, K. Schum. Fl. Bras. xii. 3, 4I8. Capi, March, I890 (767).=Mandon 82I ( fide Britton) and Rusby 660.

STERCULIACEÆ.

Melochia venosa. Sw., var. polystachya (H. B. K.) Schumann, Fl. Bras. xii. Part 3, 37. Yungas, I 890 (5I7).

Melochia, sp. n. (?) Appears distinct from all described species, but in the absence of fruit, I cannot certainly determine it. Vic. La Paz, I0,000 ft., I 890 (470).

Сhitea hirsuta (R. \& P). (Bucttneria hirsuta, R. \& P. Fl. Per. iii. IO). Yungas, I 890 (3I 7 ).

Ayenia Boliviana, sp. n., Suffruticulose, the crown many headed from a long tap-root, stems numerous, branching, slender, stellate-hispid and slightly ferruginous; stipules slender awlshaped, $2-3 \mathrm{~mm}$. long; leaves $8-15 \mathrm{~mm}$. long, on petioles half as long, oblong to obovate, acute, coarsely and sharply serrate, the mostly rounded base entire, the midrib and I or 2 pairs of nerves very prominent, and like the petioles, calyx, etc., hispidulose; flowers mostly 3 together, the fruiting pedicels at length nearly I $\mathrm{cm}$. long; calyx tube cup-shaped, less than I $\mathrm{mm}$. long, the lobes $3 \mathrm{~mm}$. long by a little more than $\mathrm{I} \mathrm{mm}$. broad, triangular with tapering acute apex; filiform claw of petals $7 \mathrm{~mm}$. long, the hood $1.5 \mathrm{~mm}$. long, nearly orbicular in outline; stamen column $2.5 \mathrm{~mm}$. long; style fully equalling the ovary.

Vic. Cochabamba, I891 (93I). Species much resembling in its general appearance some forms of $A$. pusilla, but the distinct mode of venation alone fully distinguishes it. 
TILIACEA.

Triumfetta semitriloba, L., var. Martiana, Schimp. Fl. Bras. xii. Part 3, I 35. Yungas, I 890 (465).

Corchorus hirtus, L. Sp. Pl. Ed. 2, 747. Yungas, I 890 (616).

Corchorus pilolobus, Link, Enum. ii. 72. Yungas I 890 (250, 499 and 550 ).

Vallea stipularis, Mutis in L. f. Suppl. 266. Songo, Nov., I 890. (840). = Rusby 465 .

\section{LINEÆ.}

Erythroxylon Coca, Lam. Encyc. ii. 393. The finest cultivated form. Yungas, I 890 (268).

Erythroxylon Bangir, sp. $n$. Plant wholly glabrous, the branches reddish, the younger strongly angled, the joints clothed with several pairs of closely imbricated, rigid, dark brown, triangular-ovate, acute scales, similar to but somewhat broader than the stipules; petioles stout and rigid, $4-7 \mathrm{~mm}$. long, equalling or even twice the length of the stipules; leaves 4-7 $\mathrm{cm}$. long, thick and rigid, drying very brown, especially above, oblong or oval to slightly obovate, the base obtuse to subacute, the apex acute or obtuse, commonly produced into a very short point, midrib prominent underneath, the veins slender, reticulate, margin not revolute; flowers I or few in the axils, all parts rigid, on long $(2 \mathrm{~cm}$.) pedicels, which are strongly angled and thickened upward into the open-campanulate calyxtube, which about equals the triangular obtuse lobes, these about I $\mathrm{mm}$. long and broad; petals 3-4 $\mathrm{mm}$.long, oblong, obtuse, thick, with stout brown keel and white cartilaginous margins, the crest very prominent and crumpled; stamen tube one-half or more longer than the lobes of the calyx; styles divaricate, one-half longer than the stamens; fruit oblong, obtuse at each end, apparently somewhat 3 -angled, blackish in the dried specimens.

Songo, Nov., I 890 (843).

MALPIGHIACE E.

Byrsonima crassifolia (L.) H. B. K. Nov. Gen. v. I49. Yungas, I 890 (245).

Heteropteris inacrostachya, A. Juss. Monag. Malpigh. I80. Yungas, I 890 (627).

GERANIACE E.

Geranium Carolinianum, L. Sp. Pl. 682. Vic. La Paz, 10,000 ft., I 889 ( I I 3). 
Geranium sessiliflonum, Cav. Diss. iv. 198, t. 77, f. 2. Capi, March, I 890 (788).

Geranium sepalo-roseum, sp. n. Caudex stout, branching, blackish-brown, clothed with the slender, blackish dead petioles and stipules; branches I-3 dm. long, ascending or somewhat diffuse, branching, slender, strongly channelled, pilose; radical leaves numerous, the slender petioles 5-8 $\mathrm{cm}$. long, the blade broadly cordate, $2-3 \mathrm{~cm}$. broad, 5 -cleft, the divisions mostly 3-lobed, the ultimate lobes entire or bearing I or 2 teeth, mostly acute; above somewhat hispid, underneath pilose, none of the hairs retrorse ; cauline leaves similar, rather broader and on shorter petioles; stipules pilose, weak, lanceolate, tapering, about $7 \mathrm{~mm}$. long, 3-nerved. Peduncles I-flowered, nearly 5 $\mathrm{cm}$. long, slender, slightly exceeding the leaves; sepals lanceoblong, I cm. long, somewhat rigid, pubescent, the terminal portion bright purple during the flowering period, strongly mucronate; carpels sparingly pilose.

Capi, March, I 890 (784).

Erodium moschatum, L'Her. Hort. Kew, ii. 4I4. Vic. La Paz, I0,000 ft., I 889 (I7).

Erodium cicutarium (L.) L'Her. Hort. Kew, ii. 4I4. Vic. La Paz, I0,000 ft., I 889 (25).

Tropceolum tuberosum, R. \& P. Fl. Per. iii. t. 314. Talca Chugiaguilla, Apr., I 890 (789).

Tropceolum Smithii, D. C. Prod. i. 682. Vic. La Paz, Io,ooo ft., 1889 (58). = Rusby 759.

Oxalis corniculata, L. Sp. Pl. 435. Vic. La Paz, Io,000 ft., I 886 (I 3 ).

Oxalis Yungasensis, sp. $\mathrm{n}$. Hirsute throughout, or the younger portions tomentose; roots slender, branching, stems numerous, crowded, branching from the base, slightly repent, nerved, leafy ; stipules small, partly united with the base of the petiole, ciliate ; petioles slender, $2-3 \mathrm{~cm}$. long ; leaves ternate, the leaflets cuneate-obcordate, subsessile, 10-1 $3 \mathrm{~mm}$. long and broad, both sides hirsute-tomentose ; peduncles axillary, scarcely surpassing the leaves, I-2 flowered; the bracts subulate, very small; sepals oblong, obtuse, hirsute, $3 \mathrm{~mm}$. long; petals 6-7 mm. long; styles rather stout, pubescent.

Yungas, 1890 (316). = Rusby 753. Near C. mollis, Kunth and $C$. pubescens, Kunth. 
Oxalis breviramulosa, sp. n. Stems creeping, woody, IO-I $5 \mathrm{~cm}$. long, red, smooth at the base, above villous, bearing crowded, much abbreviated branches upon which the leaves and solitary flowers are crowded; stipules united with the base of the petiole, oblong-oval, membranaceous, pubescent, and like the petiole bright red, $2 \mathrm{~mm}$. long; petiole $5 \mathrm{~mm}$. long, pubescent; leaflets 3 , sessile, obreniform, $3 \mathrm{~mm}$. long, faintly puncticulate, glabrous; peduncles scarcely $4 \mathrm{~mm}$. long, stout, pubescent, 2-bracted above the middle, the bracts lance-ovate, obtuse, pubescent, $2 \mathrm{~mm}$. long, and like the peduncles green; sepals persistent, oblong-oval, elliptical, about $3 \mathrm{~mm}$. long, white, finely many nerved, pubescent; petals spatulate-obovate, entire, about $8 \mathrm{~mm}$. long; the longer stamens $6 \mathrm{~mm}$. long, exceeding the styles (in the flowering stage) by I mm., pubescent; styles glabrous, stigma lobed; pod globose, scarcely exceeding the sepals, deeply 5-lobed, 15 -seeded; seeds $1.5 \mathrm{~mm}$. long, flattened, obovate, strongly tuberculate.

Vic. La Paz, I0,000 ft., I 890 (195).

Oxalis —. Yungas, I 890 (315). Apparently near O. scandens, H. B. K., but root, fruit and habit unknown.

\section{ZYGOPHYLLEÆ.}

Tribulus maximus, L. Sp. Pl. 386. Vic. Cochabamba, I 89I (927). Tribulus cistoides, L. Sp. Pl. 387. Vic. Cochabamba, I 89 I (962).

RUTACE E.

Ruta graveolens, L. Sp. Pl. 383. Talca Chugiaguilla, April, I890 (8 I 3). Escaped.

Zanthoxylum stipitatum, Engler, in Mart. Fl. Bras. xii. Part 2, i61. Vic. Cochabamba, I 89 I (922).

Zanthoxylum pubescens, St. Hil. et Tul. Ann. Sci. Nat. Ser. 2, xvii. I4I (?). Yungas, I 890 (462). This species, referred by Engler (Fl. Bras. xii. Part 2, I75) to Z. rhoifolium, Lam., as var. pubescens, is apparently so excessively variable as to take in this plant, although its leaflets are strongly coriaceous and entirely glabrous, and the common petiole much shorter than called for by the description.

\section{SIMARUBEÆ.}

Brunellia Boliviana, Britton, sp. n. Branches very stout, strongly angled, glaucous, above becoming, like the peduncles, etc., hispid-hirsute; leaves, including the petiole, about $3 \mathrm{dm}$. long, the petiole $4-8 \mathrm{~cm}$. long; leaflets about $61 / 2$ pairs, imper- 
fectly opposite, slightly petiolulate, the upper larger, 6-IO $\mathrm{cm}$. long, oblong-elliptical, not acuminate, obtuse, the base sub-equal, coriaceous, above shining, below glaucous; principal veins I $2-$ I 8 pairs, their direction irregular, above sulcate, below prominent; teeth sub-obsolete, tipped with a black callous point; common peduncles $3-5 \mathrm{~cm}$. long, $5 \mathrm{~mm}$. broad, strongly angled; calyx lobes closely applied to the capsules, $5 \mathrm{~mm}$, long, triangular-lanceolate, acute, sparsely hispid; follicles 5 , either sessile or stoutly pedicellate, about $15 \mathrm{~mm}$. long, the long beak recurved, densely hispid; seeds one-half the length of the capillary stalks on which they are reflexed, $3.5 \mathrm{~mm}$. long, oblong-ellipsoid, turgid, bright reddish-brown and shining, faintly reticulate.

Yungas, I 890 (664). Very mature specimens, of the female plant only seen.

Bnmellia Boliviana, Britton (?). Differing in the not glaucous, but ferruginous-tomentellate character of the branchlets, peduncles, lower leaf surfaces and inflorescence; panicles axillary and terminal, lax, $\mathrm{I}-2 \mathrm{dm}$. long including the peduncle, which is $5-8 \mathrm{~cm}$. long, less stout than in the type, angled; flowers $3 \mathrm{~mm}$. broad, the calyx teeth 5 , triangular, acute, nearly $2 \mathrm{~mm}$. long and scarcely as broad, grayish brown with white margins. Stamens IO.

Songo, Nov., I 890 (839). Specimens of the male plant, in the young flowering state, only seen. Possibly distinct.

\section{MELIACEÆ.}

Trichilia ovalis, sp. n. Branches stout, blackish, velvety; leaves i 5-40 cm. long, the common petiole $2-6 \mathrm{~cm}$. long, very thick, about equalling the internodes of the rhachis; leaflets 4-6 pairs, sessile, oval, obtuse at both ends, or the uppermost with contracted base, 6-1O $\mathrm{cm}$. long, 3-4 cm. broad, thick and coriaceous, entire, the margins strongly revolute, above slightly shining, below densely velvety and strongly veined; panicles very compound, lax and broad, pubescent; flowers sessile or short pedicelled; sepals slightly united at the base, less than I $\mathrm{mm}$. long, ovate, acutish, pubescent ; petals glabrous, narrowly oblong, the apex rounded, $4.5 \mathrm{~mm}$. long; stamen-tube $3 \mathrm{~mm}$. long, the border slightly spreading and shortly io-lobed, the anthers short and broad, sessile just within the border; pistil a little exceeding the calyx-tube, slenderly conical, flattened, grooved on both sides, bearing a broad peltate stigma. Songo, Nov., I 890 (848). Distributed as "Moschoxylon." 


\section{ILICINE $A$.}

Ilex Boliviana, Britton, sp. n. Branches gray, branchlets brownish, very leafy, and like the petioles, peduncles, pedicels and calyx, minutely puberulent; petioles $2 \mathrm{~mm}$. long, winged; lamina $3-4 \mathrm{~cm}$. long, $1.5-3 \mathrm{~cm}$. broad, oval, the base rounded or slightly narrowed, the apex with an abrupt, short, very obtuse point, crenate-dentate, coriaceous, green and shining above, white underneath, and sharply dotted with minute black glands, strongly reticulate; racemes compound, loose, 5-IO flowered, the peduncle about $8 \mathrm{~mm}$. long, the pedicels $2 \mathrm{~mm}$. long, at the base bearing 2 minute subulate bracts; flowers diœcious, the staminate only seen, these 4-merous ; calyx lobes very short and broad, the apex rounded; petals broader than long ; ovary rudimentary, depressed ; fruit (collected by Pearce) strongly depressed-globose, $4 \mathrm{~mm}$. broad, lightly 5-grooved. Yungas, I 890 (450). Distributed as "Maytenus." (Same as specimen in Herb. Kew, collected by Pearce, Santa Cruz, 6,000 ft., and one collected by Pentland, Bolivia; fide Britton.)

IleX AMygdalifolia, n. sp. Diœcious, glabrous nearly throughout; branches elongated, blackish-brown; petiole 5-8 $\mathrm{mm}$. long, $2 \mathrm{~mm}$. broad, flattened, black, densely minute-glandular; leaves coriaceous, entire, $8-15 \mathrm{~cm}$. long, lanceolate to oblong, the base rounded and usually somewhat inequilateral, the apex from short-acuminate to tapering, very acute, dark green, the veins underneath prominent and blackish, the midrib lightly sulcate above; umbels lateral, not axillary, approximate, sessile, compound, the branches $5-8$, I $\mathrm{cm}$. long, the staminate $8-15$ flowered, the pistillate fewer, on pedicels $4 \mathrm{~mm}$. long; flowers 4-merous, the calyx teeth triangulate, broader than long, slightly acuminate, acute; petals $2 \mathrm{~mm}$. long, oval, the apex rounded, thickish; in the staminate the filaments stout, two-thirds as long as the petals; the ovary rudimentary but prominent, globose; in the pistillate the stamens prominent, but with imperfect anthers; ovary globose, less than I $\mathrm{mm}$. in diameter, 4-grooved, the stigma thick and broad, 4-lobed; fruit (col. Pearce) globose, $5 \mathrm{~mm}$. in diameter, apparently 4-seeded. Songo, Nov., I 890 (842). Collected also by Pearce at Sandillana, 7,000 ft., Herb. Kew, in fruit, fide Britton.

\section{RHAMNACE $A$.}

Rhamnus Boliviana, n. sp. Divaricately much branched, the branches grayish-red, the branchlets, peduncles, calyx, etc., ferruginous tomentose; petiole about $\mathrm{I} \mathrm{cm}$. long, leaf $5-8 \mathrm{~cm}$. long by $\mathrm{I} .5-4 \mathrm{~cm}$. broad, oblong to obovate, the base narrowed but not acute, the apex acuminate and acute, finely and sharply 
but not closely serrate, rigid, reticulate, tomentose, especially below, where the veins are yellowish; peduncles a little shorter than the petioles, branched, 5-10 or I 2 -flowered; pedicels 5 $\mathrm{mm}$. long; flowers not seen; fruit obovoid, about equalling the pedicels, dry, hirsute, becoming nearly glabrous, 3-seeded. Yungas, I890 (35I). A single specimen of the same was. found among my Bolivian collections, but I was uncertain how it had come there, and rejected it.

Colletia Weddelliana, Miers, Ann. Nat. Hist. Third Ser. V. 207 ; Wedd. Chlor. And. t. 65. Talca Chugiaguilla, Apr., I 890 (793).

Colletia Foliosa, sp.n. Branches elongated, slender, all erect, green and sparsely brown-warty, the younger striate and puberulent; stipules distinct, red brown, thick, triangular-subulate and acute, $\mathrm{I} .5 \mathrm{~mm}$. long; leaves persistent, thick and rigid, oval to slightly obovate, the base somewhat rounded, the apex perfectly so, or in some slightly notched or mucronulate, midrib very prominent below, the veins somewhat so, finely pubescent on both sides, the blade $8-12 \mathrm{~mm}$. long by one-half as broad, entire, the margins sometimes revolute, the petiole distinct, I$2 \mathrm{~mm}$. long; pedicels about $3 \mathrm{~mm}$. long, erect or spreading or a few deflexed; flowers 5-merous, the base green and tumid, above yellowish, 4-5 $\mathrm{mm}$. long, campanulate, thickish, the calyx lobes triangular-ovate, obtuse, one-half as long as the tube, erect or recurved; petals about equalling the calyx teeth, distinctly unguiculate, strongly concave, elliptical-spatulate; stamens barely exserted, the filaments stout, twice or thrice the length of the anthers; ovary I $\mathrm{mm}$. long, the style stout, $5 \mathrm{~mm}$. long, barely exserted. Vic. Cochabamba, I 89 I (978).

\section{AMPELIDE $Æ$.}

Vitis sicioides (L.) Baker, var. canescens (Lam.) Baker in Mart. Pi. Bras. xiv. Part 2, 202. Yungas, I890 (32I).

Vitis trifoliata (L.) Baker in Mart. Fl. Bras. xiv. Part 2, 2 I 2. Yungas, I 890 (347).

SAPINDACE $E$.

Cardiospermum Halicacabum, L. Sp. P1. 925. Vic. Cochabamba, I 89 I (987).

Serjania dumicola, Radlk. Conspectus Serjania, p. 4, sp. no. 8. Yungas, I 890 (42 I).

Serjania reticulata, Camb., forma genuina, Radlk. Determined by Prof. Radlkofer. Yungas, I 890 (4 I 3). 
Serjania —. Very near 4I 3 , but distinct and apparently undescribed, but without fruit. Vic. Cochabamba, I 890 (879).

Schmidelia —. Yungas, I 890 (672). Specimen unfit for determination.

Dodonaa viscosa, L. Mant. 238. Yungas, I 890 (372).

ANACARDIACEÆ.

Schinus mollis, L. Sp. Pl. 388. Capi, March, I 890 (770 and 77I). Duvaua dependens (Ort.) D. C. Prodr. ii. 74. Vic. La Paz, I0,000 ft., I 890 ( I60).

Duvaua dependens (Ort.) D. C. (?). Songo, Nov., I 890 (895).

Duvaua dependens. var. subintegra, Engler, in Mart. Fl. Bras. xii. Part 2, 387, t. 8I. f. 1. Vic. Cochabamba, I89I (98I).

\section{LEGUMINOSÆ.}

Crotalaria Pohliana, Benth. Ann. Nat. Hist. iii. 428. Yungas, $1890(580)$.

Crotalaria anagyroides, H. B. K. Nov. Gen. vi. 404. Yungas, 1890 (309).

Crotalaria - Species probably undescribed, but material too poor. Vic. La Paz, I0,000 ft. (427, in part).

Lupinus Bogotensis, Benth. Pl. Hartweg. I68. Vic. La Paz, I0,000 ft., I 889 (88). = Rusby 954.

LuPinus BANGII, sp. n. Perennial from a stout, elongated, vertical root, herbaceous, branched from the base, the stem at first erect, afterward reclining and becoming naked below, stout, 2-3 dm. long, below sparingly, above densely coarse-hairy, conspicuously ribbed; raceme dense in flower and fruit, 8-1 2 $\mathrm{cm}$. long, lance-oblong, obtuse; stipules subulate, acute, $8 \mathrm{~mm}$. long, clothed with long, coarse silky hairs; petioles slender, the lower erect, $5 \mathrm{~cm}$. long, the upper spreading and shorter; leaflets mostly 7 , linear-oblanceolate, $\mathrm{I}-2 \mathrm{~cm}$. long, $2-4 \mathrm{~mm}$. wide, the base gradually tapering, the apex with a slight acumination, sericeous on both sides; inflorescence densely coarse-silky; pedicels stout, $3 \mathrm{~mm}$. long, elongating but little in fruit, the flowers nearly $1 \mathrm{~cm}$. long, blue; pods broadly oblong and much compressed, $2.5 \mathrm{~cm}$. long (exclusive of the strongly deflexed yellow style, which is $5 \mathrm{~mm}$. long), densely hairy, 5-6seeded; fruiting calyx-lobes thin, nearly smooth, $7 \mathrm{~mm}$. long; bracteoles half as long, and, like the pod, densely hairy; seeds strongly flattened, dark brown, dull, $3.5 \mathrm{~mm}$. long, $2 \mathrm{~mm}$. broad. 
Vic. La Paz, I0,000 ft., I 890 (737). = Mandon's 688.

Spartium junceum, L. Sp. Pl. 708. Near La Paz, Io,000 ft., I 889 (43).

Medicago denticulata, Willd. Sp. Pl. iii. I4I4. Near La Paz, Io,000 ft., I 890 ( I 89).

Medicago lupulina, L. Sp. Pl. 779. Near La Paz, I0,000 ft., I 890 (I42).

Medicago sativa, L. Sp. Pl. 778. Near La Paz, Io,000 ft., I 889 (45). Escaped.

Melilotus Indica (L.) All. Fl. Ped. i. 308. Near La Paz, I0,000 ft., I 889 (72). Near Cochabamba, I89 I (887).

Melilotus alba, Desv. in Lam. Encycl. iv. 63. Near La Paz, I0,000 ft., I 889 (I I 8).

Trifolium amabile, H. B. K. Nov. Gen. vi. 503. Near La Paz, I0,000 ft., I 890 (I9I).=Rusby IOI 2 , etc.

Psoralea Mutisii, H. B. K. Nov. Gen. vi. 487. Near La Paz, I0,000 ft., I 890 ( 158 ).=Rusby 957.

Dalea Boliviana, Britton, Bull. Torr. Bot. Club, xvi. 259. Near La Paz, I0,000 ft., I 889 ( I06).=Rusby 959.

Dalea Pazensis, sp. n. Suffruticose, 5-8 dm. high, erect, much branched, the long and slender branches erect, slightly pubescent, more so above; stipules nearly filiform from a triangular base, I-4 $\mathrm{mm}$. long ; leaflets 6-10 pairs, oblong, 6-9 $\mathrm{mm}$. long, $2.5 \mathrm{~mm}$. broad, cuspidate, thickish, puberulent, the petiolule less than I mm. long, the rhachis filiform, stiff and persistent; spike triangular-ovate, obtuse, $2.5 \mathrm{~cm}$. long; bracts oblong, scarious with a broad dark midrib, pubescent, $5 \mathrm{~mm}$. long, exclusive of the abrupt, filiform, very pilose point, which is nearly $3 \mathrm{~mm}$. long; calyx $4 \mathrm{~mm}$. long, strongly io-nerved. densely villous, the teeth one-third as long as the tube; corolla blue, apparently nearly twice the length of the calyx.

Near La Paz, I0,000 ft., I 890 (678). Near D. Bolizizna, Britton, but differing in the stipules, the number, form and surface of the leaflets and the length and abruptness of the acumination of the bracts. Specimens very imperfect.

Indigofera Anil, L. Mant. 293. Yungas, I 890 (246).

Cracca leptostachya (D. C.) (Tephrosia leptostachya, D. C. Prodr. ii. 25 I). Yungas, I 890 (65I). = Rusby I 343 .

Astragalus unifultus, Wedd. Chlor. And. 260 (ex. descr.). Near La Paz, I0,000 ft., I 890 (I68). 
Astragalus Mandoni, sp. n: Stems numerous from a woody base, I dm. high, blooming while erect, soon decumbent, becoming 4-5 dm. long, slender, at length scantily leafy, very finely and softly pubescent; stipules triangular, acute, villous, $6 \mathrm{~mm}$. long, closely sheathing; leaves $6-8 \mathrm{~cm}$. long, exclusive of the petioles which are $3 \mathrm{~cm}$. long; leaflets about I 2 pairs, irregularly placed, slightly petiolulate, oblong or very slightly lanceolate, IO-I $6 \mathrm{~mm}$. long by one-third as broad, both base and apex varying with age from acutish to rounded, or the apex slightly notched, villous underneath, roughish above; peduncles slender, about $7 \mathrm{~mm}$. long; racemes capitate to shortoblong, dense, $2-3 \mathrm{~cm}$. long and broad; bracts $4-5 \mathrm{~mm}$. long, triangular-ovate, tapering and acute; flowers nearly $2 \mathrm{~cm}$. long, deep blue, calyx tube nearly cylindrical, $6 \mathrm{~mm}$. long, 3 $\mathrm{mm}$. broad, deep green, about 20-nerved, the teeth 3-4 $\mathrm{mm}$. long, narrowly subulate, dark colored, densely pubescent.

Near snow line, Mt. Tunari, I89 I (I022). The same as Mandon's 709 from near Sorata.

Astragalus sinocarpus, sp. n. Suffruticose, I-2 dm. high, much branched, the branches stout, ascending or erect, terete below, above strongly angled, puberulent, internodes I $\mathrm{cm}$. long, nodes invested by the broad, semi-scarious, pubescent, acuminate stipules, which are nearly as long as the internodes; leaves about $7 \mathrm{~cm}$. long, on rather stout, channelled petioles $4-5 \mathrm{~cm}$. long; leaflets about I 2 pairs, sessile, I $2 \mathrm{~mm}$. long and half as broad, oval to slightly ovate, or the terminal slightly obovate, rounded or slightly notched at the apex, green, underneath densely, above more sparsely pilose ; racemes axillary, dense, capitate, in flower $1.5 \mathrm{~cm}$. long, I cm. broad, in fruit $2.5 \mathrm{~cm}$. long and broad, on slender peduncles $2-3 \mathrm{~cm}$. long, the latter in fruit deflexed and again ascending; flowers about I $\mathrm{cm}$. long, the corolla exceeding the calyx by half; corolla apparently whitish, the calyx teeth blackish; pods I.5 cm. long, lanceolate, upwardly falcate, tapering to a sharp stiff point, the 2 cells separated, either by a narrow sinus, or broadly divergent.

Near La Paz, I0,000 ft., I890 (I74). According to Dr. Britton, the same as Mandon's 710.

Astragalus colliculus, sp. n. From a very long, stout, woody tap-root, densely tufted to form little hillocks, the branchlets very stout, I-2 cm. long, the foliage and flowers mostly crowded at their ends; united stipules nearly semi-circular, the apex rounded, sheathing, slightly cartilaginous, yellowish, glabrous and somewhat shining, $5 \mathrm{~mm}$. long; leaves $5-10 \mathrm{~mm}$. long, on petioles of nearly or quite the same length, the latter broad and stiff, at the base dilated and sheathing; leaflets 
about 9 pairs, closely approximate or imbricated, in a few leaves at length becoming $\mathrm{I} .5$ to $2.5 \mathrm{~mm}$. long, nearly orbicular, thick, both sides densely silky; flowers large and broadly expanded, solitary or 2 together, sessile in the axils; bracts elliptical, in texture and surface similar to the stipules, about 3 $\mathrm{mm}$. long and half as broad; upon the upper side of the calyx is a very hairy bristle-shaped bractlet, about as long as the bract; calyx tube $3.5 \mathrm{~mm}$. long, and two-thirds as broad, densely villous, the teeth triangular, acute, $1.5 \mathrm{~mm}$. long, I $\mathrm{mm}$. broad; corolla deep blue, the standard nearly I $\mathrm{cm}$. long and broad; ovary lanceolate with short thick style, densely silky.

Near La Paz, I0,000 ft. (Incorrectly labelled Yungas) I 890 (660). Dr. Britton, who compared these specimens at Kew, considers them distinct from any there named, but identical with Mandon's 7II and 712, from the Bolivian Andes. Apparently the species is a very variable one. Mr. Bang's 660 includes 2 distinct forms, and both are quite different from Mandon's 7I2. The other form of Mr. Bang's collection is less stout and compact, has the leaflets only 6 pairs on longer, more slender petioles, and they are less hairy, distinctly obcordate. Mandon's plant (7I2) is more rosulate and densely white tomentose, with smaller flowers.

Astragalus - Collected with the last, and as a part of it, but evidently distinct. Material insufficient for a diagnosis. Vic. La Paz, I0,000 ft., I 890 (660 a).

Amicia Lobbiana, Benth. (As I cannot find that this species has been published, a description is here appended.) Suffruticose, widely branching and reclining, the branches very flexuous, and like the petioles, etc., densely pubescent ; petioles stoutish, I.5-3 cm. long; leaflets 2 pairs, the intervening rhachis about one-third as long as the petiole, the leaflets slightly petiolulate, $\mathrm{I}-2.5 \mathrm{~cm}$. long and broad, triangular-obovate, obcordate by a broad sinus, above dark green, glabrous, finely whitish-pinnateveined, below very pale or slightly ferruginous, the margins and veins pubescent, very finely reticulate; peduncles I-several-flowered, the bracts (purplish ?) mostly unequally reniform, flabellinerved, I-I.5 cm. broad; pedicels slender, spreading, the flowers ascending or erect; flowers at length 4 or $5 \mathrm{~cm}$. long, the black glandular calyx half as long as the. lilac-purple corolla, which is pubescent and falcate; pods not seen.

Yungas, I 890 (694). = Mandon 765, and Rusby I333. The 
plant grows luxuriantly along roadsides, in hedges and upon the borders of forests or copses.

Patagonium miraflorensis (Remy) (Adesmia miraflorensis, Remy, Ann. Sci. Ser. III. vi. 357) ex descr. Vic. La Paz, Io,000 ft., I 889 (69). = Rusby I039 and I04I.

Stylosanthes hamata (L.) Taubert, Abhand. Bot. Verein. Branden. Pl. 32, f. 22. (?) Vic. Cochabamba, I 89 I (936).

Zornia diphylla, Pers. var. latifolia (D. C.) Benth. in Mart. Fl. Bras. xv. Part I. 8I. Yungas, I890 (4I6). A nearly glabrous form.

Vic. Cochabamba, I89 I (964).

Meibomia adscendens (Sw.) Kuntze, Rev. Gen. Pl. I9 (Desmodium adscendens, D. C. Prod. ii. 332). Yungas, I 890 (408). $=$ Rusby 977 .

Meibomia supina (Sw.) Britton, Ann. N. Y. Acad. Sci. vii. (Desmodium incanum, D. C. Prod. ii. 332). Yungas, I 890 (424).

Meibomia uncinata (Jacq.) Kuntze, Rev. Gen. Pl. I97. (Desmodium uncinatum, D. C. Prod. li. 33I). Yungas, I 890 (257). Meibomia pachyrhiza (Vogel) Kuntze, Rev. Gen. P1. I97. Desmodium pachyrhizum, Vogel, Linnæa, xii. 97) ex deser. Yungas, I 890 (649).

Meibomia andina, sp. $\mathrm{n}$. Stem prostrate, slender from a woody base, scantily pilose with spreading hairs, finely many-nerved, purple, internodes about $4 \mathrm{~cm}$. long; stipules spreading, purplish, finely nerved, rigid, triangular and regularly tapering to a very acute point, a little more than $\mathrm{I} \mathrm{cm}$. long, the base 3 $\mathrm{mm}$. broad; stipellæ small, bristle-shaped; petioles hirsute, about equalling the internodes, the petiolules densely hairy; lateral leaflets spreading or deflexed, on very short petiolules, distant $5-8 \mathrm{~mm}$. from the terminal, ovate, slightly inequilateral, the base rounded, slightly apiculate, $2.5-3.5 \mathrm{~cm}$. long and nearly half as broad; the terminal one-half larger, rhombicoval, the base somewhat cuneate, the apex blunt; upper surface scabrous with scattered, conspicuous white points, the lower pubescent with stiff, stout, slightly ferruginous hairs; bracts rigid, ovate, acutely tapering, very strongly and sharply nerved; panicles small, very loose; pedicels nearly as long as the buds; calyx teeth linear-subulate, exceeding the ellipsoid tube ; flowers not seen; joints of fruit nearly elliptical, $8 \mathrm{~mm}$. long by 5 broad, strongly deflexed upon the broad stipe, which is $5 \mathrm{~mm}$. long.

Yungas, I 890 (650). Resembles M. albiflora. 
Cnuminum Virginianum (L.) Britton, Bull. Torr. Bot. Club, xviii. 269. (Centrosema Virginiana, Benth., Ann. Mus. Vind. ii. I 20.) Yungas, I 890 (356).

Cologania ovalifolia, H. B. K. Nov. Gen. vi. 4I2. Vic. Cochabamba, I 89 I (984).

Terammus uncinatus (L.) Sw. Fl. Ind. Occ. iii. I238. Yungas, I 890 (359). Differs from Rusby's I 346 in the thicker, oblong elliptical leaves, velvety on both sides.

Erythrina Crista-galla, L. Mant. 99. Songo, Nov., I 890 (822).

Galactia speciosa (D. C.) Britton, Bull. Torr. Bot. Club, xvi. 262. Yungas, I 890 (343). = Rusby I $34 \mathrm{I}$.

Dioclea lasiophylla, Mart. Ann. Mus. Vind. ii. I 34. Yungas, I 890 (472). = Blanchet I I62, fide Britton.

Dioclea coriacea (Grah.) (Dolichos coriaceus, Grah., Wall. Cat. $=$ Dioclea reflexa, Hook. f. Nig. Fl. 306.) Yungas, I $890(547)$. Canavalia villosa, Benth. Ann. Mus. Vind. ii. I 35. Yungas, I 890 (586). A form with large thick glabrate leaves, and very tomentose calyx.

Eriosema mufa (H. B. K.) E. Meyer, Comm. Pl. Af. Austr. 128. Yungas, I 890 (426).

Eriosema crinita (H. B. K.) E. Meyer, Comm. Pl. Af. Austr. I 28. Yungas, I 890 ( 427 in part-may be called 427 a.).

Eriosema simplicifolia (H. B. K.) Walp. Rep. ii. 902. Yungas, I 890 (428).

Cesalpinia pectinata, Cav. in D. C. Cat. Hort. Monspel. 84. Songo, Nov., I 890 (824).

Casalpinia (Hoffmannseggia) Bangil, sp. n. Shrub, habit unknown, the stout branches and petioles bearing dark brown subulate glands; common petiole $\mathrm{I}-2 \mathrm{~cm}$. long, the secondary very short; primary pinnæ 4 or 5 pairs, about $3 \mathrm{~cm}$. long; ultimate leaflets 7-10 pairs, on stout, black, nodiform petiolules, coriaceous, glabrous, pale, elliptical, the base slightly cordate, the apex rounded or slightly emarginate, $6-8 \mathrm{~mm}$. long, $5 \mathrm{~mm}$. broad; raceme terminal, dense, very coarse and thick, spike-like, sessile or on a very short peduncle; pedicels short, stout ; calyx reddish-brown, black-glandular, much imbricated, the lobes coriaceous, I cm. long, beautifully and strongly fringed; corolla one-half longer than the calyx, sub-coriaceous, glabrous; filaments densely pilose; ovary tomentulose; pods broadly oblong, slightly falcate, abruptly short acuminate; 
seeds about 3, compressed, nearly orbicular or somewhat broader above, purple brown, very smooth and shining.

Bolivian plateau, I891 (757).

Casalpinia (Hoffmannseggia) Fisheriana, sp. n. Shrub with lax, angulate, brown branches which, like the petioles, peduncles and calyx, are densely black-glandular; common petioles 2-3 $\mathrm{cm}$. long; primary leaf divisions about 3 pairs, $1.5 \mathrm{~cm}$. long, exclusive of the slender petiolules, which are about $5 \mathrm{~mm}$.; ultimate leaflets about 7 pairs, the lower very slightly petiolulate, coriaceous, oblong or slightly oblanceolate, the base truncate, the apex rounded, the margin with a narrow bright red border, crenate, a black gland in each sinus, about $5 \mathrm{~mm}$. long and half as broad; racemes pedunculate, several-flowered, lax; pedicels about I cm. long, slender; calyx much imbricated, sepals oblong-lanceolate, reddish with broad light colored margins, about $6 \mathrm{~mm}$. long, the petals nearly one-half longer; pod broadly oblong, slightly incurved, with a recurved, abrupt, acutely tapering point, densely beset with longish tapering glands.

Bolivian plateau, I891. ( 756 , in part, perhaps distributed as 756 a.)

C esalpivia (Hoffmannseggia) Rosulata, sp.n. Stems stout, deep purple, glabrous, apparently prostrate with short, stout, erect branches, bearing the foliage and inflorescence crowded at their summits; petioles slender, 5-8 $\mathrm{mm}$. long; primary leaf divisions only I or 2 pairs, on petiolules about $5 \mathrm{~mm}$. long; ultimate leaflets about 5 pairs, thickish, scarcely petiolulate, oblong, inequilateral and slightly upwardly curved, rounded at both ends, entire or crenulate; racemes on long, slender, crooked branches, peduncled, loosely several-flowered; peduncles slender and weak, 5-6 mm. long, and like the calyx very minutely downy; otherwise the flowers very similar to those of the last; pods slightly narrower than in the last, a little smaller, the more slender point continuing the curve of the pod, the sutures thickened, the surface beset with short, stout, black glands; seed much flattened, quadrangulate, greenish brown, dull.

Bolivian plateau, 189 I ( 756 , in part).

All these Casalpinias would be placed in Hoffmannseggia were the latter maintained distinct. Their intermediate character justifies the consolidation of the two genera as has been proposed. Cassia affinis, Benth. in Mart. Fl. Bras. xv. Part 2, 98. Yungas, I 890 (464). = Rusby 837. 
Cassia tomentosa, L. f. Suppl. 23I. Near La Paz, I0,000 ft., I 889 (49). = Rusby $98 \mathrm{I}$.

Cassia latiopetiolata, Domb.; Vogel Syn. Cass. 70. 'Vic. La Paz, I0,000 ft. I $889(24) .=$ Rusby 980.

Cassia Chamacrista, L. Sp. Pl. 538 . Yungas, I 890 (549). = Rusby 2854.

Cassia flavicoma, H. B. K. Nov. Gen. vi. 366. Yungas, I 890 (6I 3). $=$ Rusby $\mathrm{IO} 2 \mathrm{I}$.

Prosopis juliftora (Sw.) D. C. Prod. ii. 447. Songo, Nov., I 890 (823).

Mimosa Boliviana, Benth. Trans. Linn. Soc. xxx. 396. Yungas, I 890 (392). Incorrectly labelled "Vic. La Paz, Io,000 ft." $=$ Rusby $\mathrm{I} 300$.

Acacia Farnesiana (L.) Willd. Sp. Pl. iv. I083. Songo, Nov., I 890 (864).

Piptadenia communis, Benth. Hook. Journ. Bot. iv. 337. Vic. Cochabamba, I89I (921).

Pithecolobium laxiflorum, sp. n. Habit unknown, glabrous throughout, the branchlets slightly warty; stipules deciduous, not seen ; common petioles stout, $2 \mathrm{~cm}$. long, strongly nerved; leaves geminate, the secondary petioles equalling and similar to the primary; primary divisions of the leaf about $2 \mathrm{dm}$. long, including their petioles; ultimate leaflets 4-5 pairs, nearly sessile, dark brown at the point of insertion, the lowest $5 \mathrm{~cm}$. long by half as broad, the uppermost $9 \mathrm{~cm}$. long by $4 \mathrm{~cm}$. wide, all oval, obtuse at both ends, minutely cuspidate, coriaceous, prominently veiny underneath; peduncles slender, $3-4 \mathrm{~cm}$. long, the spikes loose, cylindrical, I $2-18 \mathrm{~cm}$. long; flowers crimson; calyx minute, deeply toothed ; corolla-tube cylindrical or slightly funnel form, $7 \mathrm{~mm}$. long by $2 \mathrm{~mm}$. broad; stamens very numerous, the length of the exserted portion slightly greater than that of the corolla-tube; fruit not seen.

Yungas, 1890 (625).

Inga edulis, Mart. Herb. Fl. Bras. II 3. Yungas, I 890 (236). = Rusby 995.

\section{ROSACE $E$}

Prunus Brittoniana, sp. n. Tree (?) glabrous throughout, the branches slender, blackish; petioles a little more than $\mathrm{I} \mathrm{cm}$. long, $2-3 \mathrm{~mm}$. broad, broadly channelled ; leaves very coriaceous, ovate, the base rounded but abruptly somewhat narrowed into the petiole, the apex acutish, at least in the younger leaves 
(apex broken off in all the older leaves of my specimen) the midrib strongly channelled above, prominent below, the veins prominent and strongly reticulated below; margin bearing rather distant, small, sharp, salient teeth; blade $\mathrm{I}-2 \mathrm{dm}$. long or perhaps longer: racemes simple, solitary in the axils, sessile, variable in length, but about as long as the leaves, rather loosely flowered ; pedicels about $5 \mathrm{~mm}$. long, divaricate; calyxtube $3 \mathrm{~mm}$. long, the triangular lobes I $\mathrm{mm}$. long, obtusish; petals orbicular, $2.5 \mathrm{~mm}$. long; style very thick, $2 \mathrm{~mm}$. long, the stigma broad; fruit (mature ?) nearly spherical, with a small stout point, I $2 \mathrm{~mm}$. long.

Songo, Nov. I 890 (821). = Mandon 677.

Kageneckia lanceolata, R. \& P. Fl. Per. Syst. 290. Talca Chugiaguilla, Apr. 1890 (797).= Mandon 676.

Rubus Bogotensis, H. B. K. Nov. Gen. iv. I58. Yungas, I890 (684).

Alchcmilla tripartita, R. \& P. Fl. Per. i. 68. Vic. Cochabamba, I 89 I (886).

Alchemilla pimnata, R. \& P. Fl. Per. i. 69. Vic. La Paz, I0,000 ft. I 890. (76, 659 and $660 \mathrm{~b}$, the last, perhaps, distributed as a part of 660.)

Margyricarpus CRIstatus, Britton, sp. n. Spiny shrub, with very rough scaly bark, the branches numerous, stout, erect, when young whitish, becoming blackish, the joints crowded; spines simple, $1.5-2.5 \mathrm{~cm}$. long, spreading and more or less recurved, whitish, pungent, terete above, below flattened and the base dilated to $3 \mathrm{~mm}$. broad, hoary with tightly appressed hairs, their leaflets apparently entirely obsolete; fascicled leaves linear, blunt, rigid, revolute, keeled, 5-8 $\mathrm{mm}$. long; flowers 4-or 5-merous, the calyx tube about $5 \mathrm{~mm}$. long, purple, sharply winged, the wings crenate; teeth at length spreading or reflexed, $1.5 \mathrm{~mm}$. long, spatulate-oblong, indistinctly nerved. La Paz; I 890 ( I 70). = Mandon 693.

Polylepis villosa, H. B. K. Nov. Gen. vi. 228. Capi, March, I 890 (769).=Mandon 674 .

Poterium Sanguisorba, L. Sp. Pl. 994. Vic. La Paz, I0,000 ft. I 889 (I IO).

\section{SAXIFRAGEÆ.}

Escallonia Mandon, sp. n. Glabrous, the branches reddish, the younger irregularly angled and slightly winged; leaves subsessile, oblanceolate, acute or obtuse, gradually tapering to the base, slightly revolute, minutely serrulate, underneath pale 
with the dark veins prominently reticulate, $2.5-4 \mathrm{~cm}$. long; panicles leafy at the base, oblong-pyramidal, 2 or $3 \mathrm{~cm}$. long and broad; bracts linear, acute, peduncles and pedicels sharply wing-angled, the latter I-2 $\mathrm{mm}$. long; calyx-tube $2 \mathrm{~mm}$. high, $5 \mathrm{~mm}$. broad, the teeth small, triangulate, obtuse; petals thick, white, with prominent dark, branching veins, spatulate, obtuse, the base truncate, $6 \mathrm{~mm}$. long ; filaments and style $2 \mathrm{~mm}$. long, Capi, March I890. (780).=Mandon 602.

Windmannia fagaroides (H. B. K.) Kuntze, Rev. Gen. Pl. 228. (Weinmannia fagaroides H. B. K. Nov. Gen. vi. 54.) Yungas, I 890 (669.)

Windmannia elliptica (H. B. K.) Kuntze, Rev. Gen. Pl. 228. Yungas, I 890 (3I I).

Windmannia Bangil, sp, n. Branches red-brown, sparsely ferruginous-hairy, the younger portions more so; branchlets opposite, slender, ribbed, the internodes $5-7 \mathrm{~cm}$. long; petioles stout, about I $\mathrm{cm}$. long, mostly reflexed, and like the under surfaces of the leaves, peduncles, etc., sparsely hispidulouspubescent ; leaves simple, $5-9 \mathrm{~cm}$. long, $3-5 \mathrm{~cm}$. broad, ovate, the base rounded or subcordate, the apex somewhat acuminate, acute or obtusish, closely serrate-dentate, the teeth acute or obtuse, slightly coriaceous, above glabrous and slightly shining, the veins imperfectly opposite, IO-I 5 pairs, crooked and bifurcating, rather prominent; racemes cylindrical, lax, $4-8 \mathrm{~cm}$. long, barely I $\mathrm{cm}$. broad, on peduncles about $2 \mathrm{~cm}$. long, the flowers mostly 3 together (or apparently 6 by the confluence of two fascicles); bracts brown, weak, subulate, about $1.5 \mathrm{~mm}$. long; pedicels slender, $2.5 \mathrm{~mm}$. long; flowers about $2 \mathrm{~mm}$. broad; sepals 5, triangular-ovate, $1.5 \mathrm{~mm}$. long, acutish, ciliolate; stamens about twice, and pistils about thrice the length of the sepals; fruit not seen, but sepals manifesting a tendency to persist.

Yungas, I 890 (666).

Ribes glandulosum, R. \& P. Fl. Per.t. 233, Fig. 6. Songo, Nov. I $890(865)$ := Mandon 600.

Ribes Pentlandi, Britton, sp. n. Leaves obovate-orbicular, obtuse or acutish at the apex, narrowed or cuneate at the base, firm and somewhat coriaceous, strongly 3 -nerved at the base, obtusely 3-5-lobed, crenulate-serrulate or rarely nearly entire, very resinous, dark green and shining above, paler beneath. I.5-2.5 cm. long, petioles glandular-pubescent, 4-6 $\mathrm{mm}$. long ; flowers in short axillary racemes; bracts oblong-linear, 3 $\mathrm{mm}$. long, persistent; calyx pubescent without, its lobes short, obtuse; berry globose, glabrous, about $4 \mathrm{~mm}$. in diameter. 
Talca Chugiaguilla, Apr., I 890 (798). Peru (MeLean); San. Meto (Peru ?) (Matthews); Bolivia (Pentland). All in Herb. Kew. CRASSULACE $Æ$.

Cotyledon Penuviana, Baker, Ref. Bot. No. Io. Vic. La Paz, I0,000 ft., I 890 (I48).

DROSERACEÆ.

Drosera - without flowers or fruit; near D. pusilla H. B. K. but apparently distinct. Yungas, I890 (337).

\section{HALORAGEÆ.}

Myriophyllum Titicacense, Remy, Analect. Boliv. Lake Titicaca, I 890 ( I63).

\section{MYRTACEÆ.}

Psidium pomiferum, L. Sp. Pl. Ed. 2, 672. Yungas, I890 (253).

Psidium pyriferum, L. Sp. Pl. Ed. 2, 672. Yungas, I 890.

(287 a, Perhaps distributed as a part of 287).

Psidium oöideum, Berg. var. LoNGipedunculatum, n. var. Younger portions of stem, petioles, peduncles and lower sides of leaves more densely velvety than the type; leaves elliptical, the base rounded, the peduncles and pedicels $3-5 \mathrm{~cm}$. long, the calyx tube more tumid in the bud; fruit not seen. Yungas, I 890 (287).

Myrcic lanceolata, Camb. in St. Hil. Flor. Bras. Merid., ii. 236. Yungas, I 890 (285).

Myrcia Paiva, Berg. in Mart. Fl. Bras. xiv. Part I, I79.

Yungas, I 890 (220 and 360).

Myrcia pheoolada, Berg. in Mart. Fl. Bras. xiv. Part I, 167. Songo, Nov. I 890 (830).

Myrcia (Aulonyrcia) Yungasensis, sp. n. Glabrous, the branchlets minutely striate, densely leafy; leaves $3-5 \mathrm{~cm}$. long, $2-3$ $\mathrm{cm}$. broad, obovate, the apex rounded or in some very slightly acuminate, but blunt, the base cuneate into a margined petiole $3-5 \mathrm{~mm}$. long, coriaceous, the margin revolute, shining both sides, paler below, punctate but not pellucid, midrib and veins prominent both sides; inflorescence scanty, the peduncles axillary, 3-4 cm. long, nearly twice the length of the loosely few-flowered panicle; bracts narrowly oblong, obtuse, pale, 3 $\mathrm{mm}$. long; bud broadly obconical or top-shaped; pedicels 5-8 $\mathrm{mm}$. long, slender; flowers $5 \mathrm{~mm}$. broad; sepals 5 , nearly semicircular, the larger $2 \mathrm{~mm}$., the smaller scarcely $\mathrm{I} \mathrm{mm}$. broad; 
petals ovate-semi-circular, $2-3 \mathrm{~mm}$. broad; ovary small, depressed, smooth and shining; style slender, tapering, $5 \mathrm{~mm}$. long.

Yungas, I 890 (293).

Eugenia Boliviersis, sp. n. Branchlets somewhat 4-angled and, like the petioles, under sides of the leaves and inflorescence, densely ferruginous with short hairs; petioles scarcely longer than broad; leaves thick and rigid, I-2 dm. long, 4-7 cm. broad, lanceolate, the base slightly acute, the apex acuminate, strongly and finely reticulate, above pale and shining with the midrib deeply and narrowly sulcate, the principal veins depressed, the smaller ones broad and elevated, yet sulcate, underneath the midrib and all the veins strong and prominent, the primary connected at their ends to form a strong recurved margin; inflorescence subterminal, paniculate, ample, rather lax; flowers sub-sessile; buds depressed-globose; calyx 5 or 6 $\mathrm{mm}$. broad, the lobes sub-semicircular; petals $2-3 \mathrm{~mm}$. long and somewhat broader, rounded.

Songo, Nov. I 890 (825).

\section{MELASTOMACEÆ.}

Tibouchina stenopetala, Cogn. in D. C. Mon. Phan. vii. 262. Yungas, I 890 (430).

Tibouchina Orbignyana, Cogn. in D. C. Mon. Phan, vii. 26I. Yungas, I 890 (68 I). Distributed as "Aciotis."

Brachyotum microdon (Naud.) Triana, Melast. 49. Yungas, I 890 $(595) .=$ Rusby 2340.

Meriania Boliviensis, Cogn. Bull. Torr. Bot. Club, xvii. 58. Yungas, 1890 (288). = Rusby 2246.

Graffenrieda emarginata (R. \& P.) Triana, Melast. 7 I. Songo, .Nov. I 890 (849). = Rusby 2335. Perhaps distributed as Miconia.

Graffenrieda Boliviensis, Cogn. sp. n. (Description by M. Cogniaux.) Foliis breviuscule petiolatis, coriaceis, elliptico-oblongis, sub-abrupte et obtusiuscule apiculatis, lati rotundatis vel vix emarginatis, trınerviis, nervis lateralibus marginii proximis ; floribus 5-meris, breviter pedicellatis, sub-fasciculatis; calycis limbo primum clauso demum in lobos 2-3 irregularis rupto, tubo teretiusculo.

Rami juniores vix furfuraceæ dein glaberrimi, validi, superni obscure tetragoni et satis compressi. Petiolus robustissimus, leviter furfuraceus, $2.5-3 \mathrm{~cm}$. longus. Folia utrinque glaberrima, siccitate pallide viridia, $28 \mathrm{~cm}$. longa, $14-18 \mathrm{~cm}$. lata, 
nervulis transversalibus numerosis rectis, subtus valde prominentibus. Paniculæ late pyramidatæ, satis multifloræ, 2-3 $\mathrm{dm}$. longæ, pedunculus communis glaber, robustus basi longe simplex; rami oppositi sæpius geminati, patuli, elongati, superne leviter ramulosi; pedicelli $4-5 \mathrm{~mm}$. longi. Calyx dense furfuraceus, tubo oblongo campanulato, $6 \mathrm{~mm}$. longo, lobis 5-6 mm. longis. Petala oblique obovata, 7-8 $\mathrm{mm}$. longa. Ovarium 5-loculare; stylus I cm. longus. Capsula ovoideosubglobosa, $9 \mathrm{~mm}$. crassa.-Affinis G.limbate, Triana; Cogn. in D. C. Monogr. Phan. vii. 440.

Songo, Nov. I 890 (832).

Leandra dichotoma,(Don) Cogn. in Mart. Fl. Bras. xiv. part 4, 200. Yungas, I 890 (525). = Rusby 2235.

Leandra crenata, (Don) Cogn. in Mart. Fl. Bras. xiv. part 4, I 37. Yungas, I 890 (277). Not the same as Rusby's 2306. Distributed as Miconia.

Leandra Carassana, (D. C.) Cogn., var. Estrellensis (Raddi) Cogn. in Mart. Fl. Bras. xiv. part 4, I20, ex. descr. Yungas, I 890 (3I4). = Rusby 2306 and 2307 , these having been enumerated as $L$. crenata.

Leandra Boliviensis, Cogn. sp. nov. (sect. Chaetodon).

(Description by M. Cogniaux.) Ramis junioribus petiolis pedunculisque breviter denseque villoso-tomentosis; foliis disparibus, majusculis, longiuscule petiolatis, membranaceis, oblongis, breviter acuminatis, basi obtusis vel rotundatis, margine minute denticulatis ciliatisque, 5-nerviis, sub-5-plinerviis, supra ad nervos densiuscule villosis, caeteris glabris, subtus brevissime stellato-puberulis praecipue ad nervos; paniculis terminalibus vel subterminalibus, parvis, diffusis, paucifloris; floribus sessilibus, bracteolatis, glomerulatis; calyce leviter puberulo et breviuscule sparseque hirsuto, dentibus exterioribus minutis; ovario glabro. Rami graciles, obscure tetragoni, cinerei. Petiolus $1-3.5 \mathrm{~cm}$. longus. Folia majora IO-I $3 \mathrm{~cm}$. longa ob $3.5-5 \mathrm{~cm}$. lata, minora dimidio breviora et angustiora. Paniculæ $3-4 \mathrm{~cm}$. longæ; glomeruli 2-4 flori. Calycis tubus ovoideo-campanulatus, $2 \mathrm{~mm}$. longus latusque; dentes vix .5 mm. longi. Petala late triangularia, breviter acuminata, $2 \mathrm{~mm}$. longa. Antheræ oblongæ, I mm. longæ, connectivo basi producto, postice minute calcarato. Stylus vix $2 \mathrm{~mm}$. longus, stigmate punctiformi. Species L. debilis, Cogn. (1. c. p. 674) plus minusve proxima sed valde diversa.

Yungas, I 890 (5 I4). Distributed as Miconia.

Miconia albicans, (Sw.) Triana, Melast. I I6. Yungas, I890 (43I). 
Miconia annulata (Naud.) Tri. Melast. I2I. Yungas, I890 (318). $=$ Rusby 2272,2285 and 2295 .

Miconia —_, sp. apparently near MI. gonoclada, Tri., but with only young buds. Yungas, I 890 (350).

Miconia eriodonta, D. C., Prod. iii. I 85 . Yungas, I 890 (492).

Miconia granulosa, Naud. Melast. 910, fide Cogniaux, but it is not glabrous above, and exactly equals Rusby's 2263 which M. Cogniaux thought to be undescribed. Yungas, I 890 (596).

Miconia hygrophila, Naud. Melast. 220, fide Cogniaux. Yungas, I 890 (722).

Miconia livida, Tri. Trans. Linn. Soc. xxviii. I21. Yungas, I 890. $(552)$.

Miconia - In bud only and not to be determined, but perhaps not M. nubiginosa, for which it was distributed. Yungas, I 890 (446).

Miconia rufescens, D. C. Prod. iii. I80, fide Cogniaux. Yungas, I 890 (447).

Miconia sessilifolia, Naud. Ann. Sci. Nat. Ser. 3, xiv. I8 I. Yungas, I $890(526)$. = Rusby 2270.

Miconia ternatifolia, Tri., Trans. Linn. Soc. xxviii. I 18, fide Cogniaux. Yungas, 1890 (599).

Miconia Boliviexsis, Cogn., var. (?) GLabra, Cogn., var. nov. Tota glaberrima. Folia membranacea. Alabastrum globulosum, vix. I mm. crassum. Flores perfecti ignoti. An spec. distinct? Yungas, I 890 (578).

Miconia Bangir, Cogn. sp. nov. (Sect. Amblyarrhena). Ramis robustiusculis, junioribus leviter furfuraceo-puberulis demum glaberrimis; foliis rigidiusculis, elliptico-oblongis, breviter acuminatis, basi acutis, integerrimis, 5-plinerviis, supra gaberrimis, subtus vix furfuraceis; floribus 5 -meris sessilibus vel subsessilibus, paniculatis congestis, non secundis; calyce breviter obtuseque 5 -lobato, petalis obtusis. Rami obscure tetragoni et interdum leviter quadrisulcati, cinereo-fusci superne atro-purpurei. Petiolus robustiusculus atro-fuscus, leviter furfuraceus, $1.5-2 \mathrm{~cm}$. longus. Folia supra viridi-florescentia et opaca, $2-2.5 \mathrm{dm}$. longa, $8-10 \mathrm{~cm}$. lata, nervis subtus valde prominentibus, nervulis satis prominentibus valde tenuissimeque reticulato-ramulosis. Paniculæ late pyramidatæ, valde multifloræ, I2-I4 cm. longæ, rami erecto-patuli, acute tetragoni, satis ramulosi. Calyx ovoido-campanulatus, $2.5 \mathrm{~mm}$. longus latusque. Petala obovata, $2 \mathrm{~mm}$. longa. Antheræ 
oblongæ, $2 \mathrm{~mm}$. longæ. Stylus satis gracilis, $4 \mathrm{~mm}$. longus, stigmate subpeltato. Affinis $M$. amblyandra, Naud. (Cogn. 1. c. 874).

Songo, Nov. I 890 (828).

Miconia Bangii, var. (?) Rami graciliores. Folia paulo minora, viridia, basi longiore attenuata. Flores paulo minores. Yungas, I 890 (319).

Miconia hiRTa, Cogn. sp. nov. (sect. Amblyarrhena). Ramis obtuse tetragonis, junioribus dense furfuraceo-puberulis et setulis patulis papillosis longiusculis subsparse hirsutis; foliis late ovatis, breviter acuminatis, basi saepius distincte cordatis, ' integerrimis vel vix denticulatis, 9-nerviis, supra bullis conicis setuliferis creberrime fustulatis, subtus crebre foveolatis ad nervos nervulosque hirtellis cæteris glabratis; paniculis majusculis, diffusis; floribus 5-meris, sessilibus, glomerulatis; calyce brevissime 5-lobato, superne pauci-setuloso, cæteris glabrato. Rami robusti, elongati, paulo ramulosi. Petiolus robustus 4-5 cm. longus. Folia rigidiuscula, supra viridi-purpurascentia, subtus cinerea, I-I.5 dm. longa, 9-I $2 \mathrm{~cm}$. lata. Paniculæ terminales et axillares, paulo ramosæ, I-2 dm. longæ, ramis gracilibus, patulis, elongatis, vix ramulosis, brevissime subsparseque hirtellis. Calyx campanulato-ovoideus, fuscoviolaceus, $2.5 \mathrm{~mm}$. longus, $2 \mathrm{~mm}$. latus. Petala alba, obovata, I.5 mm. longa. Antheræ late oblongæ, $1.5 \mathrm{~mm}$. longæ. Stylus filiformis, subrectus, 4-6 mm. longus, stigmate punctiformi.-Species M. acalephoides, Naud. (Cogn. 1. c. 893.) proxima. Yungas, I 890 (49I).

Miconia Biacuta, Cogn. sp. nov. (sect. Cremanium); ramis acute tetragonis, junioribus petiolis paniculis calycibusque dense furfuraceis; foliis longiuscule petiolatis, crasse coriaceis, anguste lanceolatis, basi apiceque acutis, superne obscure denticulatis, cæteris integerrimis, margine leviter revolutis trinerviis, supra glabris, subtus pilis stellatis rufis arcte adpressis dense vestitis; paniculis majusculis, valde multifloris; floribus sessilibus, 5meris; calyce ovoideo-campanulato; antheris biporosis.

Rami robusti, cinereo-fusci. Petiolus crassiusculus, $\mathrm{I}-2 \mathrm{~cm}$. longus. Folia supra intense viridi-olivacea, I-I.5 dm. longa, I.5-2.5 cm. lata, nervis supra profunde impressis, subtus valde promnientibus, nervulis rectis creberrimis. Paniculæ thyrsoideæ, congestifloræ, I 3-I $4 \mathrm{~cm}$. longæ, ramis erecto-patulis, obscuræ tetragonis. Calyx cinereo-fuscus, 3-3.5 mm. longus, apice 2.5 $\mathrm{mm}$. latus. Petala quadrato-rotundata, apice leviter emarginata, I. $5 \mathrm{~mm}$. longa. Antheræ quadrato-ovoideæ, $0.75 \mathrm{~mm}$. longæ. 
Stylus satis gracilis, apice leviter dilatatus et truncatus, $3 \mathrm{~mm}$. longus. Affinis $M$. nerïfolice, Triana. (Cogn. 1. c. 907.) Yungas, I 890 (701).

Miconia - Probably undescribed, but material insufficient for description. Yungas, I 890 (340).

Clidemia ciliata, D. Don, Mem. Wern. Soc. iv. 309, fide Cogniaux. Yungas, I 890 (448). Distributed as Ossea.

Clidemia dependens (Pav.) D. Don, Mem. Wern. Soc. iv. 307. Songo, Nov. I 890 (860).

Clidemia Rusbyi, Britton, Bull. Torr. Bot. Club, xvii. 2I I. Songo, Nov. I 890 (859).

Clidemia acutifolia, Cogn. sp. nov. (sect. Sagræa); ramis teretibus, junioribus leviter furfuraceis, vetustioribus glaberrimis; foliis breviter petiolatis, membranaceis, oblongo-lanceolatis, longe acuteque acuminatus, basi rotundatis, margine vix denticulatis et longiuscule ciliatis, 5-nerviis, supra vix furfuraceopuberulis et breviter pauci-setulosis, subtus vix granulatofurfuraceis, leviter disparibus; cymis minutis, paucifloris, divaricatus; calyce oblongo-campanulato, densiuscule furfuraceo demum glabro.

Rami graciles, cinerascentes, inferne longe denudati. Petiolus gracilis furfuraceo-puberulus, supra densiuscule barbatus, I-3 $\mathrm{cm}$. longus. Folia læte viridia, 7-I $2 \mathrm{~cm}$. longa, $2-4 \mathrm{~cm}$. lata. Cymæ I-I.5 cm. longæ; pedicelli filiformes, glabrati, 3-5 mm. longi. Flores basi bracteis 2 minutissimis subulatis caducisque muniti. Calycis tubus cinereus, $3-3.5 \mathrm{~mm}$. longus, apice I-I.25 $\mathrm{mm}$. latus; dentes exteriores patuli, triangulari-subulati, $.66 \mathrm{~mm}$. longi. Petala anguste ovata, I mm. longa. Antheræe lineares, arenatæ, I.5 mm. longæ. Stylus filiformis, deflexus, apice truncatus, $4 \mathrm{~mm}$. longus. Bacca elliptico-ovoidea, limbo calycis coronata, $2-2.5 \mathrm{~mm}$. crassa. Songo, Nov. I 890 (85 I).

Blakea repens (R. \& P.), D. Don. Mem. Wern. Soc. iv. 325. Yungas, I 890 (604).

LYTHRARIE $Æ$.

Adenaria floribunda, H. B. K. Nov. Gen. vi. I88. Yungas, I890 (374).

Cuphea ianthina, Köhne. Vic. La Paz, Io,ooo ft., I 890 (272).

Cuphea - Yungas, I 890 (677).

Material insufficient for determination. 
ONAGRARIEÆ.

Epilobium andicolum, Haussk. Oest. Bot. Zeit. I879. Vic. La Paz, I0,000 ft., I 889 (75).

Epilobium denticulatum, R. \& P. Flor. Per. iii. 78. Vic. La Paz, I0,000 ft., I 889 ( 75 a).

Perhaps distributed as a part of 75. The petals of E. andicolum are a centimeter in length.

Jussiaa Penuviana, L. Sp. Pl. Ed. 2, 555. Yungas, I 890 (248).

Enothera rosea, Ait. Hort. Kew. ii. 3. Capi, March, I890 (779). $=$ Rusby I 8 I 4 .

Enothera multicnulis, R. \& P. Fl. Fer. iii. 80, t. 317 . Songo, Nov., I890 (914).= Mandon 632.

CEnothera elongata, sp. n. Stems simple, elongated, purple, irregularly angled, like the leaves and calyx more or less pilose ; leaves sessile, 4-7 cm. long, 5-10 $\mathrm{mm}$. broad, lanceolate to narrower, apex acute, narrowed toward the base, distantly denticulate, the upper entire, somewhat thickish, the few principal veins prominent and parallel, pale, toward the apex purple-margined; flowers sessile; ovary densely pilose, barely a centimeter long, about twice as broad as the calyxtube, which (exclusive of ovary) is nearly $5 \mathrm{~cm}$. long; calyxlobes strongly reflexed, I $5 \mathrm{~mm}$. long, purple, narrow, acute; petals purple (?), drying yellowish, nearly $2 \mathrm{~cm}$. long, slightly obcordate; stamens barely equalling the petals; pod oblonglinear, slightly crowned, $2-2.5 \mathrm{~cm}$. long, $6 \mathrm{~mm}$. broad when fully mature, purplish, obtusely angled and striate, densely pilose.

Near O. mollissima. Vic. La Paz, I0,000 ft., I 889 (54).

Fuchsia serratifolia, R. \& P. Fl. Per. iii. 86, t. 325, Fig. a. Yungas, I $890(73 \mathrm{I})=$ Rusby I $80 \mathrm{I}$.

Fuchsia corymbiflora, R. \& P. Fl. Per. iii. 87, t. 325, Fig. a. Yungas, I 890 (674).

Fuchsia dependens, Hook. Ic. Pl. t. 65. Yungas, I 890 (327).

Fuchsia Boliviensis, Britton, Bull. Torr. Bot. Club, xvii. 214. Yungas, I 890 (675). = Rusby I 8 I 3 .

\section{SAMYDACEA.}

BANARA Pyramidata, sp. n. Branchlets, under sides of leaves and inflorescence densely ferruginous-tomentulose, internodes scarcely one-fourth the length of the leaves; petioles distinct, broad, 2-5 mm. long; leaves I-I.5 dm. long, 4-6 cm. wide, lance-oblong, short-acuminate and acute, the base inequilateral 
and mostly rounded, coarsely and sharply serrate, thickish, strongly veined, the veins prominent below, above slightly ferruginous, the veins more so; panicle pyramidal, peduncled, I 5-20 cm. long, 4-7 cm. broad, loosely flowered, the branches mostly ascending; flowers pedicelled, about $7 \mathrm{~mm}$. broad when fully expanded, the perianth recurved; pistil sub-glabrous, 5 $\mathrm{mm}$. long, the styles very stout; filaments filiform, two-thirds to three-fourths the length of the pistil, very slightly thickened upward, the anthers short-elliptical; mature fruit not seen, when partly mature depressed-globose, dark purple, glabrous, the style persistent and somewhat accrescent.

Yungas, I $890(365)$.

Distributed as Hasseltia, to which its resemblance is certainly very close. Very near B. Guianensis, but sufficiently well distinguished by the narrowed base of the leaves, if there were nothing else.

CASEARIA BANgir, sp. n. Large shrub, the branchlets dark purplebrown, finely warty, above slightly angled, and, like the petioles, very slightly puberulent, the plant otherwise glabrous; petioles 3-5 mm. long, stout; leaves rigid, $8-12 \mathrm{~cm}$. long, 3 or $4 \mathrm{~cm}$. broad, oblong, the base slightly acuminate, the apex more so and acutish, finely and closely serrate, the teeth mostly with minute dark incurved cartilaginous points, pellucid-punctate, pale, slightly shining above, the midrib and principal veins prominent underneath, the former angled by the decurrent veins ; umbels loose, apparently by the premature falling away of most of the flowers; pedicels erect, articulated near the base, about $3 \mathrm{~mm}$. long; calyx-tube scarcely I $\mathrm{mm}$. long, the lobes $3.5 \mathrm{~mm}$. long, oblong, thickish, concave, minutely ciliolate; filaments thickish, nearly $2 \mathrm{~mm}$. long, the anthers short, minutely pubescent; staminodia shorter than the filaments, tomentose ; ovary glabrous, globose; style stout, lanceolate, 2 $\mathrm{mm}$. long, strigose; stigma large, capitate.

Songo, Nov. I 890 ( 845$)$.

\section{LOASE $A$.}

Mentzelia Fendleriana, Urb. et. Gilg (nov. spec.) foliis omnibus manifeste (inferioribus et infimis usque ad $1.3 \mathrm{~cm}$. longis) petiolatis, lanceolatis; floribus in cymas laxas dispositis; filamentis 70 80 , inæqualibus, 10 exterioribus usque duplo ceteris longioribus ac multo latioribus; capsula obconica vel turbinata, inferne sensim in stipitem 3-4 mm. longum attenuata; seminibus 5-6alatis, ala semine ipso quadruplo angustiora; cotyledonibus quadratis, subito in radiculam subsesquilongiorem contractis. Perennans. Caulis erectus, pilis inæquilongis verticillatim glochi- 
diatis dense obtectus, superne ramosus. Folia laxa, lanceolata, regulariter dentata vel serrata, basi subcuneata, apice breviter acuminata, infima usque ad $6.2 \mathrm{~cm}$. longa $3.5 \mathrm{~cm}$. lata, sequentia sensim minora, supra pilis antrorsum spinuligeris dense obtecta, subtus pilis brevibus subæquilongis tenuissimis antrorsum spinuligeris vel verticillatim glochidiatis densissime vestita, scabra, canescentia. Calycis tubus obconicus vel turbinatus, inferne sensim attenuatus, $5 \mathrm{~mm}$. longus, superne $3 \mathrm{~mm}$. crassus, pilis longis tenuibus verticillatim glochidiatis densissime vestitus, aliis antrorsum spinuligeris rarius intermixtis; lobi ovato-lanceolati, I.3-I.4 cm. longi, supra basin $3.5 \mathrm{~mm}$. lati, longe acuminati. Petula 5 verisimiliter aurantiaca, apiculata, $2.1-2.2 \mathrm{~cm}$. longa, 0.9-I cm. lata. Stamina IO, longiora I.8 cm. longa, I. $2 \mathrm{~mm}$. lata, cetera filiformia I-I.I cm. longa, inter sese et cum petalis connata. Capsula $\mathrm{I}-\mathrm{I}$.I $\mathrm{cm}$. longa, superne 4-5 mm. crassa. Semina irregulariter ovata, flavescentia, $3 \mathrm{~mm}$. longa, $1.8 \mathrm{~mm}$. lata, medio $0.9 \mathrm{~mm}$. crassa, endospermium perpaucum vel subnullum; embryo rectus.

Habitat in Venezuela prope coloniam Tovar : Fendler n. I876; in Bolivia: Bang n. 748 et 1082 .

Cajophora Rusbyana, Urb. et Gilg (nov. spec.). caule rigido crasso erecto, foliis lanceolatis, pinnatisectis, pinnis nunquam usque ad nervum medium intrantibus, ovato-triangularibus, inter sese disjunctis, usque ad 7 -jugis, profunde dentatis vel dentato-serratis, dentibus integris; floribus in apice caulis in monochasium 2-3-florum laxissimum dispositis, 5-meris; squamis dorso filis 3 squamam multo superantibus instructis. Caulis ut videtur simplex, $40 \mathrm{~cm}$. et ultra longus, parce foliosus, pilis modice longis verticillatim glochidiatis aliisque longioribus sed inæquilongis antrorsum spinuligeris densissime vestitus, setis undique dense vel densissime intermixtis. Folia usque ad I4 $\mathrm{cm}$. longa, $4.5 \mathrm{~cm}$. lata, petiolo usque ad $4 \mathrm{~cm}$. longo instructa, supra pilis subæquilongis antrorsum spinuligeris basi sæpius bulbiformi-incrassatis laxius obtectis, subtus pilis antrorsum spinuligeris aliisque verticillatim glochidiatis densissime vestita, setis utrinque præsertim ad margines hinc inde intermixtis. Pedunculi florigeri $0.8-1.5 \mathrm{~cm}$. longi. Calycis tubus obconicus, I cm. longus, superne $5 \mathrm{~mm}$. crassus, pilis parvis antrorsum spinuligeris dense obtectus setis longis acutissimis vel urentibus horridus lobi lanceolati acuti, $2-2.2 \mathrm{~cm}$. longi, supra basin $5 \mathrm{~mm}$. lati, subintegri, sed parce ac obsolete denticulati. Petala bene evoluta $4-4.5 \mathrm{~cm}$. longa, I.8-1.9 cm. lata, $1.3-1.4 \mathrm{~cm}$. profunda, profunde cymbiformia. Squamæ $6 \mathrm{~mm}$. longæ, æque latæ et profundæ. Staminodia 2 interiora squamam multo superantia $1.5-1.6 \mathrm{~cm}$. longa, sigmoideo-curvata, supra 
basin dorso appendice densissime pilosa instructa. Stamina IOO, bene evoluta $2.5 \mathrm{~cm}$. longa. Ovarium inferum, placentis 3 late bifurcatis instructum.

Habitat in Bolivia, prope Cochabamba ( 1142 ).

CAJOPHORA HORRIDA, Urb. et Gilg, caulibus stricte erectis rigidis crassis; foliis ovatis usque late ovatis pinnatis, pinnis lanceolatis vel oblongo-lanceolatis, acutis, usque Io-jugis, profunde dentatis, dentibus angustis subrecurvatis semper acutis integris, supra setis dense vestitis vel potius horridis; floribus 7-6meris in apice caulis solitariis, pedunculis usque ad $\mathrm{I} \mathrm{cm}$. longis, post anthesin usque ad $4 \mathrm{~cm}$. acutis; squamis pilis dorsalibus squamam multo superantibus instructis, dorso carinis 3 paullo supra basin subito late prominentibus et usque ad partem $\frac{4}{5}$ squamæ alt. procurrentibus, apicem versus paullo sensim diminutis instructis, squamis ipsis margine superiore solemniter incrassatis; placentis 4 dichotomis planis; capsula oblonga vel ovati-oblonga.

Loasa horrida, Britt., msc. in Enum. Pl. Rusby in Bull. Torr. Bot. Club, xvii. (1890) p. 281.-Loasa heptamera, Britt. in Enum. P1. Rusby in Bull. Torr. Bot. Club, xvii. p. 28I, non Wedd. Caules simplices vel parcissime ramosi usque ad $40 \mathrm{~cm}$. alti, pilis modice longis verticillatim glochidiatis aliisque æquilongis antrorsum spinuligeris densissime vestiti, setis undique dense intermixtis. Folia petiolo usque ad $5 \mathrm{~cm}$. longo instructa, usque ad $15 \mathrm{~cm}$. longa, $5.5 \mathrm{~cm}$. lata. Calycis tubus obconicus $0.8-0.9 \mathrm{~cm}$. longus, superne $0.7-0.8 \mathrm{~cm}$. crassus, setis longis urentibus horridus; lobi ovato-lanceolati acuti, I.3-I.4 cm. longi, $0.4 \mathrm{~cm}$. lati, distincte regulariter serrato-dentati. Petala 2.6-2.7 cm. longa, $1.2-1.4 \mathrm{~cm}$. lata, I $\mathrm{cm}$. profunda, profunde cymbiformi-cucullata. Squamæ $7 \mathrm{~mm}$. longæ, $4 \mathrm{~mm}$. latæ. Staminodia 2 interiora squama multo longiora, I.3$1.4 \mathrm{~cm}$. longa, supra basin appendice densissime papillosopilosa instructa. Stamina I40-160, bene evoluta $1.4-1.5 \mathrm{~cm}$. longa. Capsula $2.5 \mathrm{~cm}$. longa, $2 \mathrm{~cm}$. crassa. Semina numerosissima in placentis multiseriata, minima, pulcherrime elevatim hexaëdrico-nervosa.

Habitat in Bolivia: Bridges; in provincia Larecaja, prope Sorata, Lacatia, Arrilaya, Chuchu in petrosis, alt. $3800-4200 \mathrm{~m}$. regione alpina; Mandon n. 6 I9 (p. p. in herb. Paris cum Cajophor a sphcerocarpa, Urb. et Gilg mixta); vicinis La Paz (alt. 3300 m.) M. Bang n. I7 I. Floret in Mart. 
Cajophora Buræavi, Urb et Gilg. (nov. spec) caule volubili; foliis ovatis usque late ovatis profunde serrato-dentatis, serris ovatis vel ovato-oblongis, iterum aequaliter distincte serrato-dentatis, rarius basi pinnatifido-incisis, pinnis oblongis usque oblongo-ovalibus; floribus 5 -meris; petalis $2.2-2.3 \mathrm{~cm}$. longis; squamis dorso carinulis 3 parallelis paullo vel vix prominentibus sub apice inter sese conjunctis et hoc loco acutangule sursum curvatis notatis, filis dorsalibus nullis, antice subrotundatis obsolete trilobatis, lobis rotundatis densissimeque papillosis.

Blumenbachia lateritia, Britton in Enum. pl. Rusby in Bull. Torr. Bot. Club, xvii. 28I (non Klotzch).

Caules tenues teretes laxe foliosi, pilis verticillatim glochidiatis densissime obtecta aliis antrorsum spinuligeris retroflexis dense intermixtis, setis superne non raro obviis. Folio petiolo $\mathrm{I}-3$ $\mathrm{cm}$. longo, lamina 3-5-plo breviore instructa, usque ad I I $\mathrm{cm}$. longa, $6 \mathrm{~cm}$. lata, supra pilis antrorsum spinuligeris modice longus dense obtecta, setis dense intermixtis, subtus pilis antrorsum spinuligeris densissime vestita vel subtomentosa, aliis verticillatim glochidiatis rarius intermixtis. setis rarissimis. Flores in apice caulis in monochasia I-3-flora, laxissima dispositi, penduli; pedicelli usque ad $9 \mathrm{~cm}$. longi. Petala sub anthesi erectiuscula, obovato-oblonga. Staminodia 2 interiora squamam multo superantia I.7-I.8 cm. longa, paullo supra basin rectangulari-incurvata atque hoc loco dorso appendice 2-3 mm. longa instructa. Stamina 70-8o. Capsula oblonga, usque ad $4 \mathrm{~cm}$. longa, $\mathrm{I} .3 \mathrm{~cm}$. crassa, spiraliter dextrorsum vel sinistrorsum contorta.

Habitat in Andibus Boliviæ et Peruviæ. Vidimus e Bolivia in provincia Larecaja: Mandon n. 6r8; vic. Cochabamba: M. Bang n. I I56; e Peruvia in provincia Carabaya Weddell n. 4735; Pasco: Matthews; Cumalca: Strubel n. 35 a.

PASSIFLORACE $Æ$.

Passiflora coccinea, Aublet; Mast. in Gard. Chron. I 873, 605.

Yungas, I 890 (312).

Passiflora fatida L., var. nigelliflora, Mast. in Mart. Fl. Bras. xiii. part I, 583. Yungas, I 890 (646).

Tacsonia Boliviana, sp. n. Glabrous, stems cirrhose, slender, sharply ribbed, light colored, the younger quadrangular; petioles slender, $5 \mathrm{~mm}$. long, like the principal veins and pe- 
duncles, red; leaves $2-3 \mathrm{~cm}$. broad and two-thirds as long, deeply 3 -lobed, the lobes obsoletely serrate-dentate and with a light colored narrow margin, oblong or lance-oblong, the apex rounded, $2 \mathrm{~cm}$. long, IO-I $5 \mathrm{~mm}$. broad; tendrils simple; peduncles solitary, axillary, slender, $20-25 \mathrm{~mm}$. long; involucral bracts foliaceous, distinct, elliptical oblong, entire, I-5-nerved, $7 \mathrm{~mm}$. long by $3 \mathrm{~mm}$. wide; tube of perianth Io-nerved, cylindrical, I 2-I $4 \mathrm{~mm}$. long and (as pressed) about $5 \mathrm{~mm}$. broad; calyx lobes (color?) about I.I cm. long by $5 \mathrm{~mm}$. wide, oblong; petals (violet?) about $8 \mathrm{~mm}$. long; crown very small, membranaceous, irregularly lobulated; gynœcium somewhat exserted, $2 \mathrm{~cm}$. long, the ovary oblong.

Vic. Cochabamba, I 89 I (880). Distributed as Passiflora.

\section{CUCURBITACE $Æ$.}

Melothria Hookeri, Cogn. in D. C. Monog. Phan. iii. 588. Yungas, I 890 (258). = Rusby 2065.

Sicyos trigemina, sp. n. Stems slender, yellowish, angled, pubescent with soft spreading hairs, the tendrils simple; leaves distant, the petioles 4-6 $\mathrm{cm}$. long, sparsely hispidulous; blade membranaceous, triangular-ovate, $6-8 \mathrm{~cm}$. long, 7-IO cm. broad, angulate or indistinctly 3 -lobed, narrowly acuminate, acute, the angles acutish, cordate with sinus broad and rounded or slightly truncate, 3 -nerved, the veins prominent, the principal ones successively dichotomous, underneath minutely hispid, above more sparingly so but the trichomes longer, the margin spinulose-dentate, the teeth whitish, short, stout and blunt; flowers monœcious, the staminate about I 2 , racemose in distant whorls of 3 , on slender, densely pilose peduncles $10-15 \mathrm{~cm}$. long; pedicels slender, at length $8 \mathrm{~mm}$. long, persistent after the fall of the flowers, which are $7 \mathrm{~mm}$. broad; pistillate flowers not seen, their peduncles I cm. long; fruits 3-capitate, ovoid to oblong-ovoid, compressed, slightly 2 -3-angled, when young villous, bearing few yellowish prickles from slight tubercles, $4 \mathrm{~mm}$. long by $2.5 \mathrm{~mm}$. broad (mature?) yellowish with green, abruptly acuminate apex; seed (mature?) elliptical oblong, I.7 $\mathrm{mm}$. long by I $\mathrm{mm}$. broad.

Vic. Cochabama, I 89I (99I). Distributed as Melothria.

Gurania lanata, Cogn. Diagn. Cucurb., fasc. I, 26, fasc. 2, t. I, fig. 2. Yungas, I 890 (628).

Gurania Boliviana, sp. n. Large and stout, more or less ferruginous tomentose throughout, the stem, petioles, peduncles and tendrils many-angled; petiole (but one seen) I dm. long; leaf sub-rotund, $2 \mathrm{dm}$. long and slightly broader, angulately 3lobed for one-fourth to one-third of the distance to the base, 
the lobes broadly triangular-ovate, short, acuminate and acute, the sinuses more or less rectangular, the basal lobes nearly semicircular, the basal sinus somewhat quadrangular, intruded upon by the short triangular base; margin finely spinulosedentate, underneath densely short-tomentose, above similar but scabrous, the veins very numerous and prominent below, reticulate, the 3 primary about equal, stout, sulcate, the lateral forming the basal leaf-margin for about I cm., then bifurcated; tendrils stout, simple; peduncles considerably exceeding the leaves, the flowers about I5, umbellate, the pedicels about I $\mathrm{cm}$. long and half as broad as the flowers which, when fully mature, are $20-25 \mathrm{~mm}$. long; lobes about equalling the tube, which is lanceolate-cylindrical, $5 \mathrm{~mm}$. broad, the teeth narrowly subulate, acute; petals triangular, $2.5 \mathrm{~mm}$. long, their base about coincident with the base of the anther-appendage; anther replicate below, narrowly triangular-lanceolate, $\mathrm{I} \mathrm{cm}$. long by $2 \mathrm{~mm}$. broad, the connective narrow, its appendage $1.5 \mathrm{~mm}$. long, triangular, its outline regularly continuous with that of the anther, acute, yellowish, papillose, the remainder of the anther glabrous. Other parts not seen.

Yungas, I 890 (400). Perhaps the same as Rusby's 2062, which has the leaves less rigid, the lobes more angular, nerves less prominent, peduncles much shorter than the leaves, and appendage of anther black, linear and very abrupt. Distributed as Anguria.

Cayaponia Boliviensis, Cogn. sp. nov. (sect. Trianosperma?). Monoica, tota glaberrima; foliis trifoliolatis; foliolis petiolulatis, rigidis coriaceisque, supra scabriusculis, subtus lævibus, margine minutissime remoteque denticulatis, apice acutiusculis, subæqualibus, mediano anguste obovato basi acuto lateralibus oblique ovato-oblongis, basi intus acutis extrinscens rotundatis ; cirrhis bifidis ; calycis tubo late campanulato, dentibus erectis, basi remotis, late triangularibus, acuminatis, tubo triplo brevioribus; staminum filamentis quam antheræ parvæ duplo longioribus.

Rami robustiusculi profunde sulcati læves. Petiolus robustus, sulcatus, lævis leviter tortuosus, $2-4 \mathrm{~cm}$. longus; petioluli $7-10$ $\mathrm{mm}$. longi. Foliola siccitate pallide viridia, $10-17 \mathrm{~cm}$. longa, 5-8 $\mathrm{cm}$. lata, nervis nervulisque robustis, subtus valde prominentibus, valde ramuloso-reticulatis. Cirrhi validi, profunde sulcati. Flores in racemos elongatos multiflores interdum androginos digesti; pedunculus communis axillaris vel terminalis, robustus, sulcatus, simplex vel inferne brevissime ramosus, $2-3.5 \mathrm{dm}$. longus; pedicelli sæpius dense fasciculati, I-4 mm. longi. Flores masculi parvi. Calycis tubus basi obtusus, 7-8 mm. longus, apice fere totidem latus; dentes $2.5 \mathrm{~mm}$. longi et lati. Staminum filamenta 
capillaria, basi vix dilatata et pilosula, 6-7 $\mathrm{mm}$. longa; antheræ in capitulum $3 \mathrm{~mm}$. longum et crassum cohærentes. Flores feminei ignoti. Fructus fasciculatus, globosus, glaber, lævis, fuscescens, $1.5 \mathrm{~cm}$. crassus. Semina ignota.

Songo, Nov. I 890 (9 I I).

Micrampela macrocarpa (Britton) (Echinocystis macrocarpus, Britton, Bull. Torr. Bot. Club, xvii. 284). Yungas, I 890 (533 and 6i 5a).= Rusby 2060.

Cyclanthera tomentosa, Cogn. Diagn. Cucurb. fasc. 2, 77. Yungas, I 890 (706). Determined by A. Cogniaux, who notes "forma a feuilles moins velues."

Cyclanthera pedatu, (L.), Schrad. Ind. Sem. Hort. Gott. I83I. Yungas, I 890. Cult. (38I).

\section{BEGONIACEÆ.}

Begonia fagopyroides, Kunth et Bouche, Ind. Hort. Berl. I848. Yungas, I 890 (333).

Begonia parviflora, Pœpp. \& Endl. Nov. Gen. i. 7. Yungas, I 890 (334).

Begonia sp. Near $B$. ulmifolia, but very distinct. Yungas, I 890 (406).

CACTEÆ.

* Cereus, sp. Vic. La Paz, I0,000 ft., I 890 ( I 75 ).

Cereus, sp. Vic. La Paz, I0,000 ft., I 890 ( I 76 ).

Cereus, sp. Vic. La Paz, I0,000 ft., I 890 ( I 77).

Hariota Boliviana, Britton, sp. n. Stems somewhat quadrangular and narrowly winged at the base, setose, the setæ 5-IO, yellowish-white, about $2 \mathrm{~mm}$. long; branchlets $15-30 \mathrm{~cm}$. long, foliaceous-dilated, I-2 $\mathrm{cm}$. broad, irregularly crenate, the lobes I 5-30 $\mathrm{mm}$. long, their basal portions narrowed; midrib striate and minutely papillose, the wings also finely papillose and reticulate; flowers solitary or rarely 2 or 3 , sessile in the sinuses, about $15 \mathrm{~mm}$. long, one-half to two-thirds as broad, yellow; berry nearly $\mathrm{I} \mathrm{cm}$. in diameter, globose, the truncate apex broad, at the base hairy-tufted.

Yungas, 1890 (601). = Rusby 2048.

Opuntia, species apparently undescribed, but without fruit. Vic.

La Paz, I0,000 ft., I889. (I8).

* These specimens of Cereus do not give enough information to warrant a determination. 
UMBELLIFER $Æ$.

Hydrocotyle quinqueloba, R. \& P. Fl. Per. iii. 25, t. 248, fig. b. Yungas, I 890 (697).

Hydrocotyle eccentrica, Britton, Bull. Torr. Bot. Club, xviii. 36. Yungas, I 890 (714). = Rusby I761.

Bowulesia palmata, R. \& P. Fl. Per. iii. t. 25 I, fig. b. Vic. La Paz, I0,000 ft., I 890 (196).

Bowlesia Mandoni, sp. n. Stems 2-4 dm. long, very slender, 5ribbed, above sparsely pubescent; stipules small, scarious, fimbriate; petioles $2-4 \mathrm{~cm}$. long; leaves about $15 \mathrm{~mm}$. long and somewhat broader, rotund to subreniform, cordate, 3lobed or 5 -lobed with the lateral lobes smaller; the lobes ovate with flowing outlines, the apices rounded, mucronate with rather strong dark points, above glabrous, underneath sparsely hairy, the hairs stellate-branched much above the base; peduncles several times surpassing the leaves, 3-flowered; fruits barely $2 \mathrm{~mm}$. long, I $\mathrm{mm}$. broad, ovoid, strongly ribbed, sparsely muricate.

Talca Chugiaguilla, Apr. I 890 (804). The same collected by Mandon, No. 578 .

Eryngium elegans, C. \& S. Linnæa, i. 348. Yungas, I 890 (398).

Apium leptophyllum, (Pers.) F. Mueller, in Benth. Fl. Austral. iii.

372. Vic. Cochabamba, I89I (960).

Conium maculatum, L. Sp. Pl. 243. Vic. La Paz, I0,000 ft., I 890 ( 150$)$.

Daucus montanus, Willd. in Schult. Syst. vi. 482. Yungas, I 890 (229).

\section{ARALIACE $Æ$.}

Sciadophyllum pentandrum (R. \& P.) Poir. in Lam. Encycl. vi. 747. Yungas, I 890 (548).

Sciadophyllum conicum, Poir. in Lam. Encycl. vi. 746. Yungas, I 890 (548 a). Perphaps distributed as a part of 548 , and to be distinguished by its narrow and smooth leaflets.

Sciadophillum patulum, sp. n. Stem, common petiole and peduncle unknown; glabrous; leaflets in my specimen 7 , the petiolules rather slender, sulcate, $2.5-6 \mathrm{~cm}$. long, the outer the shorter; leaflets oblong-lanceolate, with rounded base and apex abruptly contracted into an acute, triangular-lanceolate point, the outer I $\mathrm{dm}$. long by $3 \mathrm{~cm}$. broad, the central more than $2 \mathrm{dm}$. long by nearly one-half as broad, margined by a slender yellowish line and slightly revolute, coriaceous, the 
midrib elevated above and slightly channelled, the veins slightly prominent and more so below; racemes cylindrical, very loose, $6 \mathrm{dm}$. long, nearly $\mathrm{I} \mathrm{dm}$. wide, the rhachis and peduncles blackish and finely channelled, the latter slender, irregularly disposed, divaricate, about $2 \mathrm{~cm}$. long, loosely I 2-2Oflowered; pedicels slender, spreading, 5-6 mm. long; calyx 2 $\mathrm{mm}$. broad, I $\mathrm{mm}$. high, slightly dentate; corolla not seen; filaments I mm. long, the anthers a little shorter; styles 5 , in the flower erect and partly connate into a conical column which is about I mm. long; fruit (mature ?) $4 \mathrm{~mm}$. long and broad, globose-ovoid, dark red, tipped by at least a portion of the strongly recurved styles.

Yungas, I 890 (548 b). Perhaps distributed as part of 548 .

Oreopanax Rusbyi, Britton, Bull. Torr. Bot. Club, xviii. 38. Capi, March I 890 (78I). = Rusby 2654. Mr. Bang reports the flowers as very fragrant.

OreopanaX MEMBraNaCeUs, sp. n. Branches gray, strongly striate; stipules filiform, nearly $3 \mathrm{~cm}$. long and, like the petioles, peduncles, etc., lightly ferruginous-tomentose; petioles stoutish, much dilated and dark-colored at the base, finely channelled, at length $15 \mathrm{~cm}$. long; leaves membranaceous but somewhat rigid, glabrous on both surfaces, 5-7-lobed, divided to within I $\mathrm{cm}$. of the base, the ribs and veins very strong and prominent on the lower side, impressed above, those of the two lateral divisions bearing a strong, nearly basal branch on the lower side; the divisions lanceolate or lance-oblong, both ends tapering, the upper into an elongated, very slender and acute acumination, the margin finely and sharply appressed-serrate, the lateral IO-I $3 \mathrm{~cm}$. long, $3 \mathrm{~cm}$. broad, the central $2 \mathrm{dm}$. long by $3 \mathrm{~cm}$. broad; flowers capitate, about Io together, the heads panicled; panicle lax, terminal, sessile, $3 \mathrm{dm}$. long by $2 \mathrm{dm}$. broad, the branches distant, the lower slightly drooping; peduncles I cm. long; petals oblong-lanceolate, acutish, $2 \mathrm{~mm}$. long; filaments $2.5 \mathrm{~mm}$. long, anthers ovate-oblong, less than I mm. long; styles united into a conical column; fruit not seen.

Yungas, I 890 (7 16).

CAPRIFOLIACEÆ.

Viburnum lasiophyllum, Benth. Plant. Hartweg. I89. Yungas, I 890 (37 I). = Rusby 726.

Viburnum glabratum, H. B. K. Nov. Gen. iii. 429. Yungas, I 890 $(370) .=$ Rusby 2584 . 
RUBIACEÆ.

Cinchona, sp. Yungas, 1890 (5IO). = Rusby 2347, but is not $C$. condaminea.

Lygistum (Manettia) Bangir, sp. n. Branches angular, the younger portions puberulent; stipules broadly ovate, barely acute, 3 $\mathrm{mm}$. long, adnate to the petiole; petioles stout, about $5 \mathrm{~mm}$. long, somewhat membranaceous-dilated; leaves ovate, the base rounded, apex slightly acuminate but barely acute, $4-8 \mathrm{~cm}$. long, $2-3 \mathrm{~cm}$. broad, the margin entire and revolute, coriaceous, pale both sides, especially below, glabrous both sides, except a slight ferruginous pubescence along the midrib, the veins impressed above in old leaves, prominently elevated and reticulated below; flowers 6-10, in short, nearly sessile secund racemes, the peduncle, pedicels and calyx tomentose; pedicels 3-6 mm. long; calyx-tube campanulate-hemispherical, barely $2 \mathrm{~mm}$. long, the 4 lobes slightly longer, elliptical-ovate; corolla sparsely hairy, dark crimson or purple, the tube nearly cylindrical, $6 \mathrm{~mm}$. long by $2.5 \mathrm{~mm}$. broad, the lobes $3 \mathrm{~mm}$. long and broad, ovate, acute, thick, strongly pilose within; fruit not seen.

Yungas, I 890 (537).

Hillia Boliviana, Britton, sp. n. Branches dichotomous, terete or nearly so, ashy-brown, the younger portions blackish; stipules not seen; petioles broad and fleshy, 3-5 $\mathrm{mm}$. long; leaves oval-obovate, abruptly acuminate, the base slightly narrowed, 6-9 $\mathrm{cm}$. long, including the acumination which is triangular-lanceolate and about I cm. long, 3-4 cm. broad, margin entire, scarcely revolute, above glabrous and drying blackish, with the midrib prominent, below pale green and finely and densely rugose; principal bracts elliptical-oblong, 5-6 cm. long by $2 \mathrm{~cm}$. broad, drying brown, thickish and rigid, manynerved, densely minute-papillose both sides; calyx strongly nerved, the tube $3 \mathrm{~mm}$. long and broad, the limb 3-lobed, lobes ovate, acute, $5 \mathrm{~mm}$. long, $3 \mathrm{~mm}$. broad; corolla tube slightly broader above, strongly and sharply nerved, $4.5 \mathrm{~cm}$. long, 4-6 $\mathrm{mm}$. broad, the lobes I $2 \mathrm{~mm}$. long, ovate; capsules somewhat compressed, slightly curved, stout, truncate at both ends, strongly 6-ribbed with weaker intermediate ribs, striate, $9 \mathrm{~cm}$. long, I cm. broad; seeds brown, oblanceolate, nearly $3 \mathrm{~mm}$. long, granulose-roughened, the coma loose, about $\mathrm{I} \mathrm{cm}$. long. Yungas, I 890 (600). Distributed as "Bignonia ??".

Condaminea corymbosa (R. \& P.) D. C. Prod. iv. 204. Yungas, I 890 (6IO). = Rusby I 898.

MALANEA GRANDIS, sp. n. Branches stout, quadrangular, glabrous; stipules not seen; petioles glabrous, stout, $\mathrm{I}-5 \mathrm{~cm}$. long; 
leaves ovate to oval, acute, the base short-cuneate and tapering into the petiole, margin entire, not or very narrowly revolute, I $5-30 \mathrm{~cm}$. long, one-third as broad, coriaceous, pale, glabrous both sides, above slightly shining with the midrib broad and channelled, underneath prominently reticulate; bracts triangularovate, slenderly and sharply acuminate, $6 \mathrm{~mm}$. long, $3 \mathrm{~mm}$. broad; panicles 3 or 4 , terminal or sub-terminal, tomentellate, the peduncles about $4 \mathrm{~cm}$. long, stout, dark, the panicles about 8-10 cm. long, one-half to two-thirds as broad, lax and open; calyx $1.5 \mathrm{~mm}$. long, enlarging somewhat after flowering, the triangular-subulate, acute, erect teeth a little shorter than the tube; corolla $3 \mathrm{~mm}$. long, the tube short, the lobes oblong, erect, the essential organs much exserted.

Yungas, I 890 (4I8). Distributed as Chimarrhis.

Warszewiczia coccinea (D.C.) Klotsch, Mon. Ber. Akad. Wiss. Berl. I 853, 496. Yungas, I 890 (284). = Rusby 1954.

Coccocypselum canescens, Willd., ex Ch. \& Sch. Linnæa, iv. I 39. Yungas, I 890 (270). = Resembles Rusby I 896.

Hoffinannia brachycarpa, Britton, Bull. Torr. Bot. Club, xviii. Io8. Yungas, 1890 (336). = Rusby 2522.

Hoffmannia Pallida, sp. n. Branches woody and terete, pubescent, the younger parts, petioles, stipules, pedicels, etc., ferruginous-tomentose; stipules triangular, scarcely $2 \mathrm{~mm}$. long and broad, acute; leaves oblanceolate, tapering at both ends, very much so at the base into a slender petiole of the most variable length, those of the pair being very unequal, $3-8 \mathrm{~cm}$. long by $\mathrm{I}-2 \mathrm{~cm}$. wide, entire, or toward the apex sparingly and minutely toothed, above sparsely and very minutely whitestrigose, underneath very pale, similarly stigose and on the midrib and veins ferruginous-tomentulose; flowers few, the pedicels slender, the latter 5-10 mm. long; calyx tube of the open flower oblong, strongly angled, $2 \mathrm{~mm}$. long by I $\mathrm{nm}$. broad, the teeth triangular-sinuate; corolla $5 \mathrm{~mm}$. long, slender and delicate, the lobes oblong, very obtuse, surpassing by $2 \mathrm{~mm}$. the essential organs; fruit nearly globose, $4-5 \mathrm{~mm}$. in diameter, pale brown.

Yungas, I 890 (354).

Hoffmannia Pearcei, sp. n. Branches herbaceous, tetragonal, deeply sulcate, pubescent ; stipules very small, broadly triangular; leaves oval-oblong, acuminate at both ends, the base tapering into a slender petiole $\mathrm{I}-2 \mathrm{~cm}$. in length, the blade 6 to I 2 $\mathrm{cm}$. in length and about half as broad, strigose and tomentose as in the last, the midrib broad and margined; peduncles crowded, pubescent, slender, $\mathrm{I}-2 \mathrm{~cm}$. long, 5-8-flowered, the 
pedicels $3-5 \mathrm{~mm}$. long; calyx tube in flower obscurely angled, oblong-globular, the mouth constricted, the teeth small, triangular; corolla nearly $5 \mathrm{~mm}$. long, thickish, the lobes lanceoblong, acute; corolla in the bud narrowly lanceolate, acute; fruit depressed-globose, $4 \mathrm{~mm}$. in diameter.

Yungas, I 890 (498). The same collected by Pearce at Muna, I 26. Very near the last, but clearly distinguished by the branches, the larger and broader leaves, more numerous flowers, constricted calyx and thicker, acute corolla lobes.

Chomelia tenuiflora, Benth in Herb. Kew. Branches terete, light brown, above, like the peduncles, etc., pubescent, leafy; stipules not seen; petioles 5-10 $\mathrm{mm}$. long; leaves oblong, equally acuminate at both ends, cuspidate, $4-7 \mathrm{~cm}$. long, I 5$25 \mathrm{~mm}$. wide, entire, above glabrous, underneath slightly pubescent upon the midrib and very prominent, erect, primary veins, of which there are 5-7 on each side; spines opposite, arising a little above the axils, IO-I $5 \mathrm{~mm}$. long, stout, pungent with yellow points; peduncles solitary in the axils, straight, ascending, 3-4 cm. long, ribbed; bracts subulate, erect, $3 \mathrm{~mm}$. long; secondary peduncles 3-7 $\mathrm{mm}$. long, bearing 4-7 nearly sessile flowers; calyx-tube ovoid cylindrical, I $\mathrm{mm}$. long, the two shorter teeth I $\mathrm{mm}$. the two longer $2 \mathrm{~mm}$. long, thickish, rigid, narrow, acute; corolla pubescent, the tube exceeding 2 $\mathrm{cm}$. in length, I mm. broad, cylindrical, the lobes lance-oblong, slightly acuminate, acute, $4.5 \mathrm{~mm}$. long, $2 \mathrm{~mm}$. broad, thickish; fruit not seen.

Yungas, I $890(342)$. = Mathews, Peru, 1944. Collected also by Pearce at Santa Cruz.

Coussarea (?) Yungas, I 890 (366). = Rusby 2559 and Fendler's I990 from Venezuela. It will probably be found necessary to found a new genus for this plant when fuller material comes to hand.

Faramea salicifolia, Presl. Symb. Bot. 24, t. 70 . Yungas, I890 (322). = Rusby I870.

FARAMEA Bangir, sp. n. Glabrous, the branchlets quadrangular with rounded angles, deeply sulcate, like the petioles, peduncles and flowers, drying blackish; stipules ovate, acuminate, $\mathrm{I} \mathrm{cm}$. long, $6 \mathrm{~mm}$. broad, thick, erect; petioles blackish, stout, $\mathrm{I} \mathrm{cm}$. long; leaves I-2 dm. long, 25-50 cm. broad, oblanceolate, short-acuminate, cuneate, strongly coriaceous, shining, the margin revolute, sharply prominently veined underneath; panicle terminal, stoutly peduncled, loose, I dm. long, two-thirds 
as broad; pedicels slender, I $\mathrm{cm}$. long; calyx $3 \mathrm{~mm}$. broad, conspicuously toothed, the teeth narrow, the sinuses broad; corolla-tube $5 \mathrm{~mm}$. long, the lobes $8 \mathrm{~mm}$. long by $3 \mathrm{~mm}$. broad, lanceolate, partially erect, thickish ; fruit not seen.

Yungas, I 890 (368). Distributed as Coussarea.

Psychotria tomentosa (Willd.) Muell. Arg.; Schum. Fl. Bras. vi. part 6, 370. Yungas, I 890 (535).

Psychotria Marcgraavii, Spreng. Syst. Cur. Post. 79. Yungas, I 890 (495). = Rusby 1893 and (?) I 866.

Psychotria Yungasensis, sp.n. (Eupsychotria) Stout, the branches terete, greenish, glabrous; stipules triangular-lanceolate to subulate, acute, $3 \mathrm{~mm}$. long, one-half as broad; petioles I-2 $\mathrm{cm}$. long, broad, divaricate, rigid, glabrous; leaves ovate to obovate, short-acuminate, acute, the base cuneate in variable degree, I-3 dm. long by .5 to $2 \mathrm{dm}$. wide, dull or obscurely shining above, much paler below, membranaceous but rigid, glabrous both sides, the yellow veins below fine but prominent; peduncles terminal or becoming lateral, stoutish, 4-8 cm. long; panicle corymbiform, in flower 6-8, in fruit 8-1 $2 \mathrm{~cm}$. long, the branches at about $40^{\circ}$, dichotomous, sparingly subulate-bracted at the base and upon a variable number of the branches, the latter flattened, channelled, and peculiarly pubescent along the upper side with stout, stiff hairs; flowers and fruits in the forks nearly or quite sessile, or adnate upon the branch at one side; buds regularly broadening to the truncate apex, where they are externally 5-saccate, pale; expanded flowers not seen; calyx constricted above the shining ovary, the limb broader, 2 $\mathrm{mm}$. long with short triangular, pubescent teeth; corolla strongly pubescent, slightly constricted above the base, the tube 4.5 $\mathrm{mm}$. long, bearing a circle of stiff hairs at the insertion of the stamens, the thickish lobes triangular-oblong, $2.5 \mathrm{~mm}$. long, obtuse, each bearing a yellow protuberance at the tip, within ; anthers clavate, black with white margins, $3 \mathrm{~mm}$. long, onesixth as broad at the rounded apex; ovary 2 -celled, black, the style stout, white, the two spreading stigmas black; fruit depressed and compressed-globose, 2-lobed, 4-5 mm. broad, each half with 3 principal sharp nerves.

Yungas, $\mathrm{I} 890$ (597 and 598).=Rusby $\mathrm{I} 865$, determined as $P$. cornigera, Benth. (?) This name appears not to have been published, and as there is doubt as to the identity, it is deemed best to publish a new name. The species seems nearest to $P$. pubigera, Muell. Arg. 
Psychotria Baxgir, sp. n. Branchlets terete, glabrous, red, leafy; stipules triangular-subulate, acuminate, $5 \mathrm{~mm}$. long, $2 \mathrm{~mm}$. broad at the base, delicate, brown with light tips; petioles 5-10 $\mathrm{mm}$. long, brown, margined; leaves $\mathrm{I}-2 \mathrm{dm}$. or more long by 4-IO $\mathrm{cm}$. broad, oval, short-acuminate, acute, the base cuneate, glabrous, above slightly shining, reticulate, underneath the ribs sharply prominent, irregularly alternating with rather indistinct smaller ones; inflorescence terminal, becoming lateral, the peduncles solitary, stoutish, pubescent, about $6 \mathrm{~cm}$. long; bracts of the lower branches brownish, delicate, linear-lanceolate, 6 $\mathrm{mm}$. long, obsolete or nearly so elsewhere; panicle very loose. ovate-pyramidal, $6-8 \mathrm{~cm}$. long, the base $4-5 \mathrm{~cm}$. broad, pubescent; flowers few, glomerate-crowded, sessile; calyx I.5 mm. broad, the teeth triangular, broader than long, about equalling the ovary; corolla orange-colored (?), pubescent inside, stiffhairy at the insertion of the stamens, the tube $3-4 \mathrm{~mm}$. long, expanded at the throat where it is $1.5 \mathrm{~mm}$. broad, the lobes $\mathrm{I} .5$ $\mathrm{mm}$. long, ovate, the apex rounded; anthers white, linear, $2 \mathrm{~mm}$. long and one-fifth as broad; ovaries separate, brown and shining; fruit not seen.

Yungas, I 890 (404).

Psychotria FalCata, sp. n. Branchlets terete, glabrous, dark brown; stipules brown, triangular, inequilateral, obtuse, $3 \mathrm{~mm}$. long by $2 \mathrm{~mm}$. broad; petioles I-2 cm. long, dark brown; leaves I-2 $\mathrm{dm}$. long by $5-8 \mathrm{~cm}$. wide, ovate or the lower obovate, shortacuminate at both ends, obtusish, rigid, dark green, not shining, glabrous, except the midrib, which is puberulent on both sides; peduncles terminal, solitary or accompanied by two smaller ones, about $3 \mathrm{~cm}$. long, dark brown, puberulent; bracts narrowly linear, the lower $\mathrm{I}-2 \mathrm{~cm}$. long, the upper small, setaceous; panicle lax, pyramidal, IO-I $2 \mathrm{~cm}$. long, 8-IO $\mathrm{cm}$. broad, the rhachis much swollen at the joints, the branches opposite, strongly falcate, abruptly depressed at first, then strongly upwardly curved; flowers pedicelled, the pedicels bearing two short, broad, thick branchlets; calyx barely $2 \mathrm{~mm}$. broad, the teeth triangular, green, about equalling the ovary; corolla-tube $5 \mathrm{~mm}$. long, the triangular ovate obtuse teeth $2 \mathrm{~mm}$. long, two-thirds as broad; anthers $2 \mathrm{~mm}$. long by onefifth as broad; style crooked.

Yungas, I890 (5I6). A species strikingly peculiar in the origin of the branches of the panicle and in its crooked style.

Psychotria stipularis, (Benth.) (Palicourea stipularis, Benth. Pl. Hartweg. I 33). Yungas (536). = Hartweg, Peru, 749, fide Britton. 
Psychotria Guianensis, (Aublet) (Palicourea Guianense, Aublet, Fl. Guian. t. 66) (?). Yungas, I 890 (579). Apparently the same as Aublet's figure, but lacks flowers.

Psychotria (Palicourea) Flavifolia, sp. n. Glabrous, the branchlets stout, dark-brown, ribbed; stipules nearly $5 \mathrm{~mm}$. long and broad, triangular, blunt, thickened, rigid; petioles short, consisting of the narrowed base of the leaf, which is $\mathrm{I}-2 \mathrm{dm}$. long, scarcely one-third as broad, oblong, equally short-acuminate at both ends, coriaceous and rigid, shining on both sides, strongly yellowish in drying, much paler below, the midrib and veins prominent both sides, the former 3-sulcate above; peduncles stout, about I $\mathrm{dm}$. long, the panicle about as long and onehalf as broad, compound, rather dense, the branches ascending; basal bracts subulate, acute, rigid, recurved, $4 \mathrm{~mm}$. long; pedicels manifest, stout; calyx $3 \mathrm{~mm}$. broad, the lobes a little shorter than the broadly hemispherical tube, nearly semicircular; corolla externally puberulent, the tube $6 \mathrm{~mm}$. long, slightly gibbous at the base and unequally dilated at the throat, the internal ring $2 \mathrm{~mm}$. from the base, the lobes $3.5 \mathrm{~mm}$. long, narrowly triangular-ovate, obtusish; anthers $2.5 \mathrm{~mm}$. long by two-thirds as broad, oblong; fruit not seen.

Yungas, I 890 (346).

Rudgea tomentosa, sp. n. Branchlets stout, sub-glabrous, flattened and broadly channelled on the upper side; stipules blackish with whitish lacineæ, the blackish portion broader than long, at length 3-cleft, each lobe bearing about 3 narrowly subulate, rigid, pungent lacineæ which are longer than the lobe; petioles stout, I-2 cm. long; leaves I-2 dm. long, 6-IO $\mathrm{cm}$. broad, ellipitical-ovate, very short-acuminate, obtusish, the base abruptly narrowed, very coriaceous, the margin strongly revolute, above dark and shining, with the midrib lightly sulcate and its branches impressed, underneath light gray-green, finely tomentose, the ribs strong and prominent, I I to I 3 pairs with smaller ones irregularly intervening, in direction somewhat irregular; peduncles strongly channelled, ferruginouspubescent, $6-8 \mathrm{~cm}$. long, about equalling the pyramidal, rather loose panicle, which is two-thirds as broad as long, its branches at about $45^{\circ}$, the branchlets I-3-flowered, the bracts scarcely. any; flowers sessile; calyx-tube (blackish) proper about I mm. long, the throat constricted, the limb connate about one-half its length, the teeth broadly triangular, obtuse, barely $0.5 \mathrm{~mm}$. long, yellowish-ciliate; corolla-tube sparsely pubescent, $5 \mathrm{~cm}$. long, the throat somewhat irregularly expanded, the lobes very nearly equal, lanceolate, obtusish; anther lanceolate, about 2 mm. long; fruit not seen.

Yungas, I 890 (367). 
Nertera depressa, Gærtn.; Banks in Gært. Fruct. i. I24. Yungas, 1890 (700).

Diodia _. Probably undescribed, but requires comparison.

Vic. Cochabamba, I 890 (949).

Borreria capitata (R. \& P.) D.C. Prod. iv. 545. Yungas, I8go (397). = Rusby 1936.

Borreria —. Too young for determination. Yungas, 1890 (376).

Borreria —. In same state as last. Yungas, I890 (473).

Borreria —. Probably undescribed, but requires comparison. Vic. Cochabamba, I891 (937). Distributed as Diodia.

Endlichera umbellatı (Spreng) Schum.; Mart. Fl. Bras. vi. Part 6, 38. Vic. Cochabamba, I891 (1000).

Richardia scabra, L. Sp. Pl. 330. Vic. Cochabamba, I89I (885 and 944). = Rusby 1969.

Relbunium vaillantioides (C. \& S.) Schum. in Mart. Fl. Bras. vi. Part 6, I I 5. Yungas, I 890 (269 and 5 I8). = Rusby I 828.

Relbunium pusillum (Endl.) Schum. in Mart. Fl. Bras. vi. Part 6, I 7 . Vic. La Paz, I0,000 ft. (35). = Rusby I 842 (and I 837 ?). Relbunium compactum, sp. n. Glabrous, the roots perennial, densely tufted, reddish, slender, woody; stems densely tufted, slender, ascending, very leafy, I-2 dm. long, the internodes one-half longer than the leaves, strongly sulcate, the angles rounded; leaves sessile, oblong to slightly lanceolate or slightly oblanceolate, 4-8 $\mathrm{mm}$. long, I-2.5 $\mathrm{mm}$. broad, acute, the younger minutely pointed, strongly revolute, thick, rigid, dark green, the midrib very strong and prominent underneath, the veins obscure, the upper surface rough-wrinkled in drying; peduncles axillary, solitary, scarcely half the length of the leaves, mostly erect or ascending, stoutish, narrowly 4-winged, terminating in 4 leaf-like bracts about the solitary sessile fruit; flowers not seen; bracts unequal, one pair slightly longer, the other slightly shorter than the fruit, which is compressed, the broad outline sub-rotund, 2-lobed, not deeply sulcate, very minutely tuberculate-roughened, about $2 \mathrm{~mm}$. broad.

Talca Chugiaguilla, April r 890 (8or).

Galium Plumosum, sp. n. Roots not seen, the stems slender, diffuse, light colored, sharply angled, shortly but strongly retrorse-hispid, the internodes 4-5 times the length of the leaves, the branches short; leaves sessile, 5-8 or $9 \mathrm{~mm}$. long, I-I.5 $\mathrm{mm}$. wide, oblong to linear-oblong, acutish, obscurely 3-nerved, more or less revolute, hispid, ciliate; flowers few, the inflores- 
cence very laxly cymose, leafy; mature bud broadly pearshaped, I.5 $\mathrm{mm}$. long; flowers yellowish-white, about $3 \mathrm{~mm}$. broad, on slender reflexed pedicels $2-3 \mathrm{~mm}$. long; fruit blackish, small, densely white-hairy, the hairs long and straight. Vic. Cochabamba, I89I (760).

\section{VALERIANEÆ.}

Valeriana Pavonii, Poepp., in Herb. Kew. fide Britton, Bull. Torr. Bot. Club, xviii. 263. Yungas, 1890 (298).=Rusby 2160.

Valeriana paniculata, R. \& P. Fl. Per. i. 4I, t. 70 . Yungas, I890 (I 54). Distributed as Phyllactis. $=$ Rusby 870 and 883 .

Valeriana scandens, L., Sp. Pl. Ed. 2, 47. Yungas, I 890 (594). Valeriana Boliviana, Britton, Bull. Torr. Bot. Club, xviii. 263. Yungas, 1890 (326).=Rusby $871,875,877,872$ (1237 ?). To Dr. Britton's description I would add the following: Leaves above coarsely or bristly hairy upon and near the teeth; flowers solitary and sessile in the bracts; fruits $2.5 \mathrm{~mm}$. long, strongly compressed, the broad outline ovate, sharply 5 -ribbed, the calyx-limb broad, crown-shaped, sharply Io-ribbed, about as long as the pappus.

\section{COMPOSITÆ.*}

Vernonia laurifolia, D. C. Prod. v. 30 (?). Yungas, 1890 (617). $=$ Rusby $\mathrm{I}_{6} \mathrm{I} 7$ (?).

Vernonia scorpoides, Pers. Ench. ii. 404. Yungas, $1890(222$ and 405). = Rusby I 704.

Vernonia paucifolia, sp. n. Stems several from a stout woody crown (root not seen), the stems in my specimen about $4 \mathrm{dm}$. long, rather stout, strongly many striate, densely ferruginoushirsute, bearing, a little below the middle, 4 or 5 leaves of very

* Great difficulty in the determination of Compositæ from Bolivia has been caused by Schultz-Bipontinus, who has published (Bull. Soc. Bot. France, xii.) a large number of names without descriptions, or anything which can assist us in deciding whether we have these species in hand, unless we have access to the types bearing Mandon's numbers. Even this is not sufficient in many cases, as Mandon's spceimens referring to the different numbers appear to be considerably mixed. Under these circumstances we are frequently obliged to choose between leaving the specinen undetermined until comparison can be made abroad, and disregarding the published names altogether. The latter alternative is not desirable, as it relieves synonomy to adopt the published names whenever possible. In all cases where I am certain of the identity of my specimens with those of Mandon, I have used the name of Schultz. Bipontinus and appended a description for the benefit of those who may follow. 
irregular size, the lowest about $4 \mathrm{~cm}$. long by one-third as broad, the uppermost $10 \mathrm{~cm}$. long by $6 \mathrm{~cm}$. wide, sessile, ovalelliptical to obovate, some with an obscure blunt acumination, obsoletely crenate-dentate, thick, above harsh, lepidote and very sparsely hairy, the veins and margin hirsute, the veins prominent, the first pair long, making the leaf sub-3-nerved, below densely ferruginous-tomentose ; panicle exceeding a decimeter in breadth, scarcely so long, of few pedunculate, secund, sub-sericeous branches, subtended by small, linear-lanceolate bracts; heads loose, on short, stout peduncles, about $8 \mathrm{~mm}$. long including the pappus; involucre at first turbinate, about $4 \mathrm{~mm}$. broad, becoming campanulate to broadly hemispherical; scales few, 3 or 4 serialled, thick and rigid, ovate-lanceolate, tapering, acute, hirsute, brown, $4 \mathrm{~mm}$. long by one-third as broad; akenes compressed, hairy, about $2 \mathrm{~mm}$. long, the pappus coarse, I-serialled.

Yungas, I 890 (247).

Elephantopus angustifolius, Sw. Prod. I I 5. Yungas, I 890 (344).= Rusby I 59I.

Elephantopus spicatus, B. Juss. in Aubl. P1. Guian. 808. Yungas, I 890 (357).=Rusby I 109.

Elephantopus tomentosus, L., Sp. Pl. 8 I 4. Yungas, I 890 (497).

Adenostemma viscosum, Forst. var. Brasilianum, Benth. Fl. Austr.

iii. 463. Yungas, I 890 (294).

Ageratum conyzoides, L. Sp. Pl. 839. Yungas, I 890 (235 and 407).

Stevia compacta, Benth. Pl. Hartw. I9I (?) Vic. La Paz, I0,000 ft., I 889 (86). = Rusby I6 3 . This specimen does not agree at all with Bentham's description " pappo minuto coronoformi," for the pappus is long, setose and purple. But it agrees with specimens so labelled in Herb. Columb. Coll., one of them "Matthews, Int. Peru," which is apparently that cited by Bentham in his description.

Stevia Boliviensis, Sch. Bip. Bull. Soc. Bot. France xii. 8I, name only. Stem tall, stout, hollow, reddish, striate, below glabrous, hispidulous-pubescent upward, above bearing few, distant, slender, widely spreading branches in pairs; lower leaves early dying, the upper opposite, the petioles stout, about I $\mathrm{cm}$. long, the blade $5-8 \mathrm{~cm}$. long by $2-3 \mathrm{~cm}$. broad, rhomboidal-ovate, obtuse, somewhat tapering at both ends, serrate-dentate, or crenate-dentate, rather thin, above dark green, below pale, drying yellowish or brownish, prominently veined, the lowest pair considerably stronger, above sparsely hispid-pubescent, underneath less harsh; heads glomerate-crowded at the ends of 
the branches, sessile or nearly so; involucre cylindrical or the mouth slightly expanded, $6 \mathrm{~mm}$. long; scales of the involucre proper 5, linear-oblong, acuminate, strongly curved, hispid, three-fourths the combined length of akene and corolla; flowers 5 ; akene (immature) $3 \mathrm{~mm}$. long, slenderly oblanceolate, sharply angled, hispidulous; corolla nearly $4 \mathrm{~mm}$. long, exclusive of the spreading lobes, which are I $\mathrm{mm}$. long and ovate-acuminate; pappus deficient or nearly so on one side, on the other side of two nearly equal slender awns.

Yungas, I 890 (260).

Mandon's 242, on which the species is founded, I have not seen; but with that specimen Dr. Britton has matched my I6I4, and with the latter Mr. Bang's specimen agrees. It also agrees with a part of Mandon's 244, which is said to consist in part of $S$. Boliviensis. It is therefore reasonably certain that the determination is correct.

Stevia stenocephala Sz. Bip. Bull. Soc. Bot. France, xii. 8I, name only. (?) Mr. Bang's specimens are poor and I am not positive that they agree with any portion of Mandon's 245, which Schultz-Bipontinus says is partly S. stenocephala. Even if they did, what portion of Mandon 245 is S. stenocephala? We have no description whatever! Vic. La Paz, 10,000 ft., I 890 (6 I I).

Eupatorium longipetiolatum, Sch. Bip. Bull. Soc. Bot. France, xii. 8I, name only. Fruticose, the stems terete, light brown, glabrous, much wrinkled; branches striate, spreading widely, their internodes $2-3 \mathrm{~cm}$. long, the upper portions, petioles, leaves_-both sides-peduncles, etc., ferruginous-tomentellate ; petioles $\mathrm{I}-2 \mathrm{~cm}$. long, stoutish, divaricately spreading; leaves 5-8 cm. long, $2-4 \mathrm{~cm}$. broad, deltoid-ovate, acuminate, the base varying from broadly cuneate to subtruncate, irregularly crenate, toward the apex nearly entire, thick; inflorescence corymbose-paniculate, 6-1 $2 \mathrm{~cm}$. broad, 4-7 cm. high, subternate by the greater elongation of the lowest pair of branches, very dense; heads distinctly peduncled, 6-7 $\mathrm{mm}$. high ; involucral scales few, very imperfectly imbricate, $2 \mathrm{~mm}$. long, oblongobovate, acute, puberulent; flowers, including the akene, 5-6 $\mathrm{mm}$. long, the corolla broadly funnel-form with short broad lobes, slightly exceeding the rather sparse and coarse pappus; style branches nearly $5 \mathrm{~mm}$. long, very much exserted; mature akene black, linear-oblanceolate, very strongly 5-angled, scabrous.

Songo, Nov. I 890 (867). = Mandon 257. 
Eupatorium Guanaiense, Britton, Bull. Torr. Bot. Club, xviii. 333. Yungas, I 890 (4I7). = Rusby I 735.

Eupatorium Guadalupense, Spreng. Syst. Veg. iii. 4I4. Vic. La. Paz, I0,000 ft., I 890 (504). = Rusby I603, not Rusby I 606 nor I 609.

Eupatorium Guaaalupense? Yungas, I890 (254). Near E.paniculatum Schrad. Must be compared further.

Eupatorium (?) Eleutherantherum, sp n. Shrubby, the branches opposite, erect, stout, reddish-brown or reddish-gray, striate. glandular-scurfy, naked below; petioles 3-6 $\mathrm{mm}$. long, rather broad, scurfy; leaves $2-4 \mathrm{~cm}$. long, IO-I $5 \mathrm{~mm}$. broad, lanceolate to lance-ovate, long-tapering, the base cuneate to subrotund, thick, coarsely serrate-dentate, slightly revolute, a pair of prominent veins from near the base, reticulate, scabrous both sides; inflorescence densely scabrous, corymbose-paniculate, dense, $6-12 \mathrm{~cm}$. broad; heads stoutly peduncled $8-9 \mathrm{~mm}$. long exclusive of the peduncle; involucre campanulate, lax, the scales 8 in two series, sub-equal, green and scurfy, thickish, especially the outer, linear-oblong, obtuse, $5 \mathrm{~mm}$. long, about I $\mathrm{mm}$. broad; corolla dilated in its upper two-thirds, about $6 \mathrm{~mm}$. long, the lobes barely I $\mathrm{mm}$. long, broadly ovate, obtusish; anthers reaching nearly to the corolla lobes, nearly $2 \mathrm{~mm}$. long, not at all coherent, the base truncate or very minutely produced.

Vic. La Paz, I0,000 ft., I 889 (27), I 890 (193). Peculiar in the genus for its heavy, rank odor and its distinct anthers. Distributed as Stevia.

Willoughbya officinalis (Mart.) Kuntze, Rev. Gen. Plant. 372. (Mikania officinalis Mart. Fl. Bras. vi. Part 2, 221, t. 62). Yungas, I890 (252).

Willoughbya cordifolia (L.) Kuntze, Rev. Gen. Plant. 372. (Mikania cordifolia Willd. Sp. Pl. iii. I743.) Yungas, I 890 (696). Willoughbya Bangir, sp.n. Stems climbing, reddish, lightly manysulcate, minutely pubescent; petioles I $-2 \mathrm{~cm}$. long, pubescent; leaves $6-12 \mathrm{~cm}$. long, $2-6 \mathrm{~cm}$. broad, ovate or elliptical, shortacuminate, obtusish, the base rounded, sub-5-nerved, the outer pair of nerves incomplete, finely reticulate, the principal veins impressed above, prominent underneath, minutely strigose both sides; secondary panicles axillary, IO-I $5 \mathrm{~cm}$. long, their peduncles nearly one-half as long as the subtending leaf; heads very loosely arranged in very slender racemes, on short peduncles, oblong with truncate base, $3 \mathrm{~mm}$. long by I $\mathrm{mm}$. broad, the scales brown, chartaceous, minutely papillose; flowers 
scarcely half the length of the scales, the corolla short-campanulate, half as broad as long, slightly shorter than the stout pappus, the lobes oblong, elongated; akene obovoid.

Yungas, I890 (639 a).=Matthew, Peru, I737, and Lechler 2315, fide Britton.

Solidago polyglossa, D. C. Prod. v. 332. Yungas, I 890 (449). Aster marginatns, var. acaulis (Wedd.), Sch. Bip. Bull. Soc. Bot.

Fr. xii. 8I. (Aster acaulis Wedd. Chlor. And. i. I89, t. 33,

Fig. a). Songo, Nov. I 890 (916).=Rusby I 7 I 8.

Aster Vahlii (Gaud.), H. \& A. Comp. Bot. Mag. ii. 49 (??). Vic.

Cochabamba, I89I (94I).= Rusby 2720. I have named this specimen in accordance with Dr. Britton's determination of mine, but it will require farther study.

Erigeron Bonariense, L. Sp. Pl. Ed. 2, I 2 I I. Yungas, I 890 (234). $=$ Rusby $166_{4}$ and $166_{5}$.

Erigeron Canadense, L., Sp. Pl. 863 (?). Vic. La Paz, I0,000 ft., I889 (124).= Rusby I666. The several plants occurring in various parts of South America which have been referred to this species require study. This one appears nearly identical with specimens in the Columbia College Herbarium labelled E. spiculosum, H. \& A. Distributed as Conyza.

Erigeron floribundum (H. B. K.), Sch. Bip. Bull. Soc. Bot. Fr. xii. 81. Vic. La Paz, I0,000 ft., I 890 ( I 49).=Rusby 27 I 3.

Erigerox Pazensis, Sch. Bip. Bull. Soc. Bot. Fr. xii. 8o. Name only. Stems fascicled, erect, 3-6 dm. high, light brown or purplish, striate, scabrous, branched above, the branches erect, somewhat flexuous; leaves numerous, strongly ascending, 3-6 $\mathrm{cm}$. long, I.5-3 $\mathrm{mm}$. wide, linear, narrowed to the clasping base, strongly I-nerved, grayish-green, scabrous; elongated erect branchlets bearing I to several linear-subulate bracts and terminating in solitary heads, which are about $\mathrm{I} \mathrm{cm}$. long and $\mathrm{I}_{5}$ $\mathrm{mm}$. broad, the involucre broadly hemispherical, its scales loosely imbricate, about $7 \mathrm{~mm}$. long, linear subulate, grayish pubescent; receptacle $6 \mathrm{~mm}$. broad, nearly flat, papillose; akene $2.5 \mathrm{~mm}$. long, oblong, compressed, the edges sub-alate, light grayish brown, hispid; pappus scant, serrulate, slightly exceeding the involucre.

Vic. La Paz, I0,000 ft., I 889 ( 14 and 67).=Rusby 1662 and I 663 .

Erigerox Brittonianum, sp. n. Root stout, woody, vertical, the stems several, short, thick, woody, densely crowded, $3-5 \mathrm{~cm}$. high; leaves rosulate, densely crowded, 6-1 $2 \mathrm{~mm}$. long, I-2 $\mathrm{mm}$. 
broad, spatulate, densely silky canescent both sides, sub-petiolate by the narrowed base, which is broadly dilated, reddishbrown, sub-glabrous and cartilaginous at the point of insertion; heads terminal, solitary, nearly sessile, large, $\mathrm{I} \mathrm{cm}$. or more broad, their peduncles bearing I or 2 long, linear bracts; involucral scales rather numerous and crowded, 2-serialled, unequal, lance-linear, tapering, the apex recurved, thickish, the middle portions dark, outside canescent like the leaves ; receptacle $3 \mathrm{~mm}$. broad, deeply foveolate; rays $35-50$, white or purplish, narrowly linear-spatulate, involute and stiff on drying, exceeding the scales; tubular corollas about $5 \mathrm{~mm}$. long, equalling or lightly exceeding the pappus, greenish, the lobes dark purple; akene oblanceolate, nearly truncate, sparingly stiff-hairy; pappus white, flexuous, finely toothed.

Songo, Nov. I 890 (9 I 3).

Conyza Yungasensis, sp. n. Canescent, the stem stout, erect or the base slightly depressed, about a meter high, strongly and rather sharply angled; leaves sessile and sub-decurrent, the lowest I 5 $\mathrm{cm}$. long by $5 \mathrm{~cm}$. broad, spatulate-oblanceolate, sub-petiolate by the long narrowed base, blunt, laciniately coarse-dentate, perhaps sometimes lobed, the teeth rounded, apiculate, some of them bearing I or 2 small teeth, pale below, where the midrib is strong and prominent, scabrous and hirsute both sides, upwardly becoming narrower and entire, the uppermost linearsubulate, tapering from the broad sessile base; panicles small, loose, rather few flowered; mature heads about i $5 \mathrm{~mm}$. broad, otherwise closely resembling those of $C$. Chilensis; receptacle $6 \mathrm{~cm}$. broad: akene oblong-oblanceolate, abruptly narrowed at the insertion of the long, white pappus.

Yungas, I 890 (202). Very near C. Chilensis, Spreng., but differing in the much stouter and more leafy habit, smaller and more numerous heads, akene one-half longer, lighter, not truncate at the insertion of the pappus, which is longer, more copious and not cinnamon-colored.

Baccharis cassinoides, D. C. Prod. v. 4I2. Yungas, I890 (286). $=$ Rusby 1570 .

Baccharis heterothalmoides, Britton, Bull. Torr. Bot. Club, xix. 4.

Vic. La Paz, I0,000 ft. I 889 (105). = Rusby 1709.

Baccharis alpina, H. B. K. var. serpyllifolia (Decne.) Wedd. Chlor. And. i. I68 (?) Talca Chugiaguilla, April, I 890 (802).

In the paucity, length and narrowness of the involucral scales, the length of the pappus and the light color of the akene, this seems pretty clearly distinct from B. alpina; but until the male 
plant is seen I cannot separate it from this polymorphous species.

Baccharis aphylla, var. Boliviensis. Sch. Bip. Bull. Soc. Bot. Fr. xii. 81. Yungas, I890 (620). Staminate plant only. = Rusby I 567 .

Baccharis trimera, D. C. Prod. v. 425. Yungas, I890 (692). = Rusby 1564 . We have in the herbarium excellent fruiting specimens of B. genistilloides, Pers., of the Wilkes' Exploring Expedition from Peru, exactly equalling Matthew's 193 from Peru; but they are very distinct from Mr. Bang's specimens, which are identical with Mandon's 203 and Rusby's I 564 . It, therefore, seems to me that $B$.trimera is distinct from $B$. genistilloides, Pers.

BACCHARIS MiCROPHYLla, var. (?) PULVerulenta, n. var. Pale yellowish, the branchlets and leaves rusty-scurfy, the latter strongly revolute and beset underneath with large black glands.

Vic. La Paz, I0,000 ft., I 889 (74).=Rusby I 566.

Baccharis trinervis (Lam.), Pers. Syn. ii. 423. Yungas, I 890 (512).

Somewhat more rigid and coriaceous than Rusby's specimens.

Baccharis retusa, D. C. Prod. v. 4I2. Yungas, I 890 (394).= Rusby 1572 .

Baccharis glutinosa, Pers. Syn. ii. 425. Vic. Cochabamba, I89 I (754).=Mandon 197 .

Baccharis subalata, Wedd. Chlor. And. i. I74. Yungas, I890 (690).= Mandon 202.

Baccharis hemiprionoides, Buck, Bull. Soc. Bot. Fr. xii. 8I. Vic. La Paz, I0,000 ft., I889 (IOI).= Mandon I 86.

Heterothalmus Boliviensis, Wedd. Chlor. And. i. I79, t. 3 I, fig a.

Vic. La Paz, I0,000 ft., I 889 (28).=Rusby I698.

Pluchea odorata (L.) Cass. Dict. 423 (?). Songo, Nov. I 890 (866).

Vic. La Paz, I0,000 ft., I 890 ( I78). Distributed as Moquinia. Tessaria absinthioides, D. C. Prod. v. 457. Vic. Cochabamba, I 89 I (753).

Pterocaulon virgatum (L.) D. C. Prod. v. 454. Yungas, I890 $(423)$. = Rusby I6 I I.

Achyrocline saturioides (Lam.) D. C. Prod. vi. 220. Vic. La Paz, 1 0,000 ft., I 890 (239). 
Achyrocline ramossissima (Sch. Bip.) Britton, Bull. Torr. Bot. Club, xix. I48. Name only. Stems more or less procumbent at the base, the leafy branches erect, slender, flexuous, I 5-30 cm. long, branching, luteo-lanate; leaves narrowly linear to linear-lanceolate, $2-5 \mathrm{~cm}$. long, closely sessile, above bright yellowish-green and pilose, underneath densely luteolanate; panicle broad and lax, the heads crowded at the ends of the branchlets into compound glomerules which are about I $\mathrm{cm}$. in breadth; heads about $4 \mathrm{~mm}$. long, lanceolate in the bud, narrowly campanulate when expanded; scales ovate, acuminate, green at the base, closely imbricated; flowers about 5 , the pappus and corolla about equalling the involucre; akenes $0.6 \mathrm{~mm}$. long, oblong with sharply contracted apex, light brown, glabrous.

Vic. Cochabamba, i 89i (99).

Achyrocline venosa, sp. n. Suffruticose, sparingly branched from near the base, the branches erect, strict, simple, 3-5 dm. long, leafy below, sparsely so above, terete, obscurely striate, finely lanate; leaves linear-oblong to lanceolate or oblanceolate, acute, tapering into a slender margined petiole which on the larger leaves is about $15 \mathrm{~mm}$. long, dilated at the base, the blade proper 4-7 $\mathrm{cm}$. long by 5-15 $\mathrm{mm}$. broad, above dark and very finely and closely lanate, below flavescent and densely though finely lanate, the midrib very strong, strongly triplenerved, the larger with an additional pair from near the middle, the secondary veins prominent; infloresence loosely paniculate, the branches from the upper axils, the heads closely glomerate at the ends of the branchlets, the ultimate glomerules about $7 \mathrm{~mm}$. broad, yellowish-white, floccose at the base and among the heads, which are 4-5 $\mathrm{mm}$. long, at first lanceolate and acutish, at length cylindrical or even slightly campanulate; scales 9, ovate, acute, strongly concave, very thin and transparent, $3 \mathrm{~mm}$. long by a little more than I $\mathrm{mm}$. broad; flowers 5 , equalling or very nearly equalling the scales; akenes (not mature) very small, elliptical-obovoid; corolla narrowly funnel-form, yellowish ; style-branches stout, about onefourth the length of the corolla.

Vic. Cochabamba, I891. Specimen unique, sent as part of 99. May be called 99 a. At first regarded as Gnaphalium.

Gnaphalium spicatum, Lam. Encycl. ii. 757. Vic. La Paz, I0,000 ft., I 889 (42). = Rusby I 594 and I 595.

Gnaphalium cheiranthifolium, Lam. Encyc. ii. 752. Vic. La Paz, I0,000 ft., I 890 (192). = Rusby I 593 and I 597.

Gnaphalium Weddellianum, Rusby (G. capitatum (Wedd.) Griseb. 
Symb. Fl. Arg. 186, not of Thunb. nor Lam.) Capi, March, I 890 (776).

Gnaphalium, sp. probably undescribed, but requires farther comparison. Vic. La Paz, I0,000 ft., I 890 (26I).

Elvira biflora (L.) D. C. Prod. v. 503. Yungas, I 890 (502). $=$ Rusby $235 \mathrm{I}$.

Clibadium asperum (Aubl.) D.C. Prod. v. 506. Yungas, I 890 (361).

Acanthospermum australe (L.) Kuntze, Rev. Gen. Plant. 303. Vic. Cochahamba, I89I (884).

Acanthospermum xanthoides, D. C. Prod. v. 521. Yungas, I890 (324).

Parthenium hysterophorus, L. Sp. Pl.988. Vic. Cochabamba, I 891 (948).

Franseria artemesioides, Willd. Sp. Pl. iv. 374. Vic. La Paz, Io,000 ft., I 889 (63).

Xanthium spinosum, L. Sp. Pl. 987. Vic. La Paz, Io,o0o ft., I 890 (I43).

Zinnia pauciflora, L. Sp. Pl. Ed. 2, I269. Vic. La Paz, I0,000 ft., I 890 (207).

Siegesbeckia orientalis, L. Sp. Pl. 900 . Yungas, I 890 (466).

Jageria hirta (Lag.) Less., Syn. Comp. 223. Yungas, I 890 (443). $=$ Rusby 1618 .

Wulffia baccata (L. f.) Kuntze, Rev. Gen. Plant. 373. Yungas, I 890 $(489)$. = Rusby 1705 and 1706.

Stemodontia (Wedelia) elongata, sp. n. Stems slender, elongated, climbing, channelled, puberulent ; petioles very slender, I-2 cm. long; leaves $4-7 \mathrm{~cm}$. long, $1.5-3 \mathrm{~cm}$. broad, deltoidovate, acuminate, acute, the base abruptly slightly produced, sparingly serrate with slender acute teeth, membranaceous, slenderly 3 -nerved, conspicuously but finely reticulate, minutely scabrous both sides; peduncles terminal, elongated, the head solitary; involucre hemispherical, $\mathbf{I} \mathrm{cm}$. broad, scabrous-pubescent; scales strongly 3-nerved, thick, the outer about $5 \mathrm{~mm}$. long by $2 \mathrm{~mm}$. broad, with foliaceous tips, the inner one-third shorter, wholly rigid, with rounded or apiculate apex; rays strongly nerved, more than $\mathrm{I} \mathrm{cm}$. long; disk convex to subconical, $8 \mathrm{~mm}$. high including the receptacle. Material insufficient for dissection.

Yungas, I 890 (685). 
Stemodontia (Wedelia) (?) Apparently of this genus, but more material is required. Songo, Nov. I 890 (896).

Eleutheranthera medralis, Sch. Bip., Bot. Zeit., I 866, I65. Vic. La $\mathrm{Paz}, \mathrm{I0}, 000 \mathrm{ft}$., I 890 (503).

Oyedæa Pearcei, sp. n. Stem stout, branching, leafy, scabrous and ferruginous, especially above, the branches strongly ascending; petiolies 5-1O $\mathrm{mm}$. long, broad, the base dilated and clasping; leaves $5-10 \mathrm{~cm}$. long by $1.5-3 \mathrm{~cm}$. broad, lanceolate, acuminate at both ends, obsoletely sinuate-dentate, slightly revolute, thick and rigid, scabrous and strigose both sides, the veins impressed above, prominent and pilose underneath; heads I to several at the ends of the branches; involucre hemispherical, $7 \mathrm{~mm}$. broad, $5 \mathrm{~mm}$. high, the scales about 3 -serialled, hairy, thick and rigid with recurved foliaceous tips, ovate, strongly concave with the margins spreading, about $5 \mathrm{~mm}$. long by 2 or $2.5 \mathrm{~mm}$. broad; rays about 10 , oblong, nearly $15 \mathrm{~mm}$. long, thick, pubescent outside, the 3-5 principal nerves keeled exteriorily, their akenes nearly $2 \mathrm{~mm}$. long, obovoid-triangular and slightly winged, from each angle a serrulate seta nearly as long as the akene; disk-corollas about $5 \mathrm{~mm}$. long, the limb very short, their akenes similar to those of the rays but 2winged, with 2 principal setæ and two or three smaller ones intervening.

Yungas, I 890 (546). Collected also by Pearce at Santa Cruz, fide Britton. Distributed as Zexmenia.

Viguiera Pazersis, sp. n. Stems stout, erect, much branched, angled, scabrous, the short stout hairs from white blister-like elevations, divaricately spreading, the branches strongly ascending, rather sparsely leafy; leaves sessile, or the lower shortpetiolate, $3-7 \mathrm{~cm}$. long, I to nearly $3 \mathrm{~cm}$. broad, lanceolate to ovate, short-cuspidate, the base subcuneate, the margin obscurely serrate and finely erose, upper surface dark green, underneath grayish-green with the slender veins prominent and pilose, both sides very scabrous, the upper more coarsely so ; heads solitary on the long peduncles, some of which bear I or 2 small leaves; heads, exclusive of the rays, nearly I.5 $\mathrm{cm}$., exceptionally $2 \mathrm{~cm}$., high and $2 \mathrm{~cm}$. broad; base of the involucre concave, the lateral outline of the fruiting head reniform; disk-corollas $5 \mathrm{~mm}$. long, the tube abruptly much dilated at the base, the dilated portion sub-globular, the lobes bright yellow, scarcely I $\mathrm{mm}$. long, flaccid and spreading or recurved; anthers black, $2.5 \mathrm{~mm}$. long; style-branches long, very strongly recurved; ảkenes pubescent, black, obscurely striate, triangular-oblanceolate, $4 \mathrm{~mm}$. long, the apex truncate and nearly $1.5 \mathrm{~mm}$. broad, the 2 setae very slightly shorter than 
the akene, subulate, serrulate, several smaller ones between; the enveloping scales pubescent, $7 \mathrm{~mm}$. long.

Vic. La Paz, I0,000 ft., I 889 (44). = Rusby I683, I684 and 2714. This species, though closely related to the next, is well distinguished by its smaller leaves, sessile with different pubescence and apex, broader heads, doubly more numerous and smaller disk flowers, the form and size of corolla tube and especially in the relative length of akene, disk scale and setæ, and the style-branches not twisted.

Viguiera Mandoni, Sch. Bip. Bull. Soc. Bot. Fr. xii. 79. Name only. Leaves more or less petioled, $5-15 \mathrm{~cm}$. long, $2-5 \mathrm{~cm}$. broad, above strigose and scabrous, below tomentose, ovate, the apex gradually, the base abruptly acuminate, entire or very obscurely serrate, the margin minutely revolute, thickish, 3ribbed, the ribs connected by the secondary veins; peduncles stout, monocephalous; heads, exclusive of the rays, $2 \mathrm{~cm}$. broad and about as high, the base little if at all concave, the lateral outline of the fruiting head nearly circular; involucre about I cm. high, gray-hairy, the scales lanceolate, long-acuminate, prominently I-or 3-nerved; rays 2 or 3 times the length of the involucre; disk-corollas $6 \mathrm{~mm}$. long, the tube cylindrical, very slightly dilated below, the lobes pale, erect, rigid; anthers black, $3 \mathrm{~mm}$. long; style branches strongly spirally twisted; akenes $3 \mathrm{~mm}$. long, triangular-obovate, the blackish apex truncate, I.5 mm. broad, below light brown, strongly ribbed, pubescent, the setæ aristate, fully as long as the akene, purple, serrate, the enveloping scale $8 \mathrm{~mm}$. long.

Vic. La Paz, I0,000 ft., I 890 (382).=Mandon 35, not Rusby I683 nor I 684 .

Verbesina - Vic. Cochabamba, I89I (974). Possibly the same as Rusby I $72 \mathrm{I}$.

Verbesina -. Vic. La Paz, I0,000 ft., I 889. (No. 4 in part, having the leaves small and not decurrent. May be regarded as No. 4.) Possibly this is $V$. Mandoni Sch. Bip.

Verbesina -. Vic. La Paz, I0,000 ft., I 889. (No. 4 in part, having erect, elongated, decurrent leaves. May be called No. 4 a). I incline to the opinion that all these specimens are distinct from one another and from all collected by Mandon or myself; but, recognizing the wide limits of variation in this genus, I shall secure abundant material before determining.

Bidens andicola, H. B. K. Nov. Gen. iv. 237. Vic. La Paz, 10,000 ft., I 890 ( 16 and I $4 \mathrm{I}$ ). = Rusby I688. 
Galinsoga Calva, sp. n. Annual, stems 5-30 cm. long, slender with long internodes, simple or branching from the base, the branches erect; leaves sessile or sub-petioled by the tapering bases, which are slightly connate, I 5-30 $\mathrm{mm}$. long, 2-8 $\mathrm{mm}$. broad, lanceolate to oblanceolate, the upper linear and bract-like, tapering at both ends, sparingly and coarsely serrate, hirsute both sides, veiny below; heads few, solitary, peduncles axillary and in the forks, the heads 3 or $4 \mathrm{~mm}$. high and broad; involucre hemispherical to campanulate, the scales, a few of the outer somewhat foliaceous though more or less rigid, the inner slightly longer and narrower, scarious; rays few, purple or purplish, the exserted portion $1.5 \mathrm{~mm}$. long and broad, triangularobovate, deeply and sub-equally 3 -lobed, the included portion about I $\mathrm{mm}$. long, their akenes broader than those of the disk, radially compressed, the pappus rudimentary and narrow; disk-corollas of the same color as the rays, strongly and coarsely pubescent, broadly funnel-form, scarcely $2 \mathrm{~mm}$. long, one-half as broad, strongly 5-lobed, the lobes triangular-ovate, acutish, the pappus about extending to the base of the lobes, narrowly oblong, awned, fimbriate; akenes of the disk flowers black, I.5 to nearly $2 \mathrm{~mm}$. long, obovoid, angled, the angles hispid.

Talca Chugiaguilla, April, I 890 (809). Also collected subsequently in the vicinity of Cochabamba (I I48). The nomenclature of this species is extremely complicated and puzzling. A specimen in Herb. Columb. of Mandon's No.8 $\mathrm{I}$, which is published by SchultzBipontinus in Bull. Soc. Bot. Fr. as G. calva, is a good specimen of $G$. pariflora; but Dr. Britton says that the specimen of this number in the Herb. Kew agrees with the one which I have above described. Dr. Britton says nothing about Mandon's No. 80 at Kew, referred to the same species by Sch. Bip., and of which there is no specimen in our herbarium. This difficulty effectually prevents my crediting the name to Schultz-Bipontinus, which I am not required to do, as his name is "nude." Mr. Baker (Fl. Bras., vi., Part 3, I67) increases the difficulty by referring this plant to Jegeria hirta, var. glabra. So far as this reference applies to Mr. Bang's specimens it is wrong, for they are certainly good Galinsoga. The subject is even farther complicated by the atonishing action of Dr. Watson in calling Pringle's No. I282 Jageria calva, Sch. Bip. Schultz never employed the combination thus quoted, and would unquestionably denounce such a combination as an error. Mr. Pringle's plant is a good Jageria 
and must probably stand as $J$. calva, Watson, being totally unlike the plant which I have in hand. While I am very desirous of retaining so many as possible of the names of Schultz, and giving him credit for the same, I feel that safety requires that this name henceforward be written Galinsoga calva, Rusby.

Calea robusta, Britton, Bull. Torr. Bot. Club, xix. 151 . Yungas, I 890 (429). = Rusby 2 I 37.

Schkuhria abrotanoides, Roth. Cat. i. I16. Vic. Cochabamba, I89 I $(755)=$ Mandon $7 \mathrm{I}$, except that in that specimen all the 8 scales of the pappus are equally aristate, while in Mr. Bang's plant every alternate one is small and unappendaged. Distributed as Pectis, corrected by Mr. Canby.

Schkuhria pusilla, Wedd., var. major, Sch. Bip. Bull. Soc. Bot. Fr. xii. 88. Vic. Cochabamba, I 892 (966).

Flaveria Contrayerba, Pers. Syn. ii. 489. Vic. Cochabamba, I89 I (968).

Tagetes pusilla, H. B. K. Nov. Gen. iv. 194. Vic. La Paz, 10,000 ft., I 889 ( 53 in part. The involucre is only two-thirds as long as in T. multiflora, and is expanded above). Capi, March, I 890 (772). = Rusby 21 33 .

Tagetes multiflora, H. B. K. Nov. Gen. iv. 194. Vic. La Paz, Io,000 ft., I 889 ( 34 and 53 in part, the latter perhaps distributed as 53 and may be called 53 a). = Mandon 66 .

Tagetes graveolens, L. Herit. in D. C. Prod. v. 644, ex descr. Vic. La Paz, I0,000 ft., I 889 (29).

Pectis sessiliflora, Sch. Bip. Bull. Soc. Bot. Fr. xii. 81. Name only. Stems numerous from a perennial base, prostrate or ascending, about I dm. long, stout, purple, angled, above very slightly puberulent, very leafy; leaves opposite, sessile, I 5-20 $\mathrm{mm}$. long, linear, the apex and margins long-aristate, thickish, revolute, above glabrous, underneath bearing 2 or 4 rows of very large dark-colored glands; heads mostly solitary, sessile at the ends of the leafy branches, about $\mathrm{I} \mathrm{cm}$. high and nearly as broad; involucre campanulate, of about 6 scales which are elliptical, thickish, about $8 \mathrm{~mm}$. long, by $4 \mathrm{~mm}$. broad, glandular like the leaves; receptacle globular, papillose; rays few, about equalling the pappus; akenes slender, obconical, black, pilose; pappus coarse, strongly serrate, longer than the slender, tubular, equally 5 -lobed corolla, the setæ dilated at the base.

Vic. Cochabamba, I891 (746). = Mandon 238. 
Cephalophora robusta, sp. n. A rank smelling perennial with stout widely branching root, the broad crown invested by the blackened leaf remains, the stems numerous, ramose, leafy, ascending, very angular, puberulent above; perfect radical leaves not seen, apparently very similar to the cauline, which are 3-6 cm. long, once pinnatifid into 5-7 linear, entire, obtuse or acutish divisions, the lower $10-25 \mathrm{~mm}$. long, $2 \mathrm{~mm}$. broad, somewhat fleshy, strongly nerved, minutely scabrous ; peduncles erect, stout, monocephalous $3-5 \mathrm{~cm}$. long, sharply ribbed; heads rayless, hemispherical, the larger I $5 \mathrm{~mm}$. broad, IO $\mathrm{mm}$. high; involucral scales 2-ranked, sub-equal, closely appressed, puberulent, broadly ovate or rhomboidal, about $6 \mathrm{~mm}$. long by $4.5 \mathrm{~mm}$. broad; receptacle conical, $4 \mathrm{~mm}$. high, $3 \mathrm{~mm}$. broad, pitted; akenes (in flower) triangular obconical, truncate, $3 \mathrm{~mm}$. long, the apex I mm. broad, densely clothed with coarse silky hairs; pappus of 5 very thin, scarious scales, which are broadly ovate, $1.5 \mathrm{~mm}$. long exclusive of the awn, the margin more or less erose or lacerate; corolla $3 \mathrm{~mm}$. long, stout-cylindrical or above slightly dilated, pubescent.

Vic. Cochabamba, I89I (925).

Chrysanthemum Parthenium (L.) Pers. Syn. ii. 462. Vic. La Paz, I o,000 ft., I 889 (20).

Anthemis Cotula, L. Sp. Pl. 894. Vic. La Paz, I0,000 ft., I 889 (I 28).

Plagiocheilus species requiring further study. Vic. Cochabamba, I 892 (965).

Artemisia Absinthium, L. Sp. Pl. 848. Vic. La Paz, I 0,000 ft., I 889 ( I 3 I).

Liabum hastatum (Wedd.) Britton, Bull. Torr. Bot. Club, xix. 263. Yungas, I 890 (670).

Senecio vulgaris, L. Sp. Pl. 867. Vic. La Paz, I0,000 ft., I 889 (I I 7 ).

Senecio attenuatus, Sch. Bip. Bull. Soc. Bot. Fr. xii. 80. Name only. Suffruticose, much branched from the base, branches erect, stout, flexuous, irregularly ridged, grayish-green, scurfy ; petiole about 5 or even IO $\mathrm{mm}$. long, the leaves I $5-40 \mathrm{~mm}$. long, 7-20 $\mathrm{mm}$. broad, oblong-lanceolate to ovate, obtuse or acutish, the base broadly cuneate, coarsely laciniately toothed or sub-lobed, revolute, thickish, below coarsely and sparsely hispid or hirsute, above puberulent; heads corymbosely crowded at the ends of the branches, bracted, short-peduncled, about I $3 \mathrm{~mm}$. high; involucre campanulate, 8-10 $\mathrm{mm}$. wide, densely grayish pubescent, slightly exceeded by the disk- 
flowers; rays about 8 or IO; akenes nearly $4 \mathrm{~mm}$. long, oblong, truncate, angular, brown, canescent.

Vic. La Paz, I0,000 ft., I 889 (70); I 890 ( I 80).=Rusby I 7 I 7. Senecio clivicolus, Wedd. Chlor. And. i. I 30. Vic. La Paz, I0,000 ft., I 890 (145). = Rusby I670, etc.

Senecio floccosus, Britton, Bull. Torr. Bot. Club, xix. 264, where, by a typographical error, it appears as floscosus. Songo, Nov. I 890 (870). = Rusby I680 and I 720.

Senecio Bangir, sp. $n$. Shrubby and branching at the base, the stems several, slender, erect, $2-3 \mathrm{dm}$. long, the younger portions slightly floccose; leaves $2-3$ times the length of the internodes, the petioles I 5-20 $\mathrm{mm}$. long, margined, the blade 3-5 $\mathrm{cm}$. long, I $5-25 \mathrm{~mm}$. broad, oblong to ovate, obtuse, the base obtuse to truncate or somewhat cordate, irregularly sinuately dentate or lobed, above dark green, sparsely and finely lanate, below more densely lanate; peduncle terminal, about the length of an internode, the secondary of about the same length, erect, slender, 4-6 in number, bearing solitary heads and several filiform bracts above the middle ; involucre broadly cylindrical or slightly campanulate, I $\mathrm{cm}$. long and nearly as broad; scales I-ranked, but slightly imbricated, linear, tapering and acute; rays about I5; disk-flowers and akenes very slender, the latter (in flower) linear, $4 \mathrm{~mm}$. long, the corollas $6 \mathrm{~mm}$. long; pappus very fine, minutely serrulate.

Capi, March, I 890 (778).

Senecio Clavifolius, sp. n. Shrubby, the stem low, horizontally branching, blackish, rough, the secondary branches erect, sparsely spiniferous, the branchlets interlocking, above green and fleshy, minutely and sparsely downy; leaves alternate, very fleshy, sub-clavate, upwardly curved, sessile, the apex furnished with a minute black mucronation, bearing I or 2 pairs of obscure teeth near the apex, 5-8 $\mathrm{mm}$. long, $2 \mathrm{~mm}$. broad, slightly lanate when young; heads mostly solitary, terminating the short branchlets; involucre $6 \mathrm{~mm}$. high, $5 \mathrm{~mm}$. broad, the outer scales several, very small, the principal ones imbricate and connate at the base, oblong, acuminate with black incurved tips which are continuous with the dark green middle portion, thick and somewhate rigid, about IO in number; rays 7-IO, $8 \mathrm{~mm}$. long, the 3 lobes oblong, fully I mm. long; disk-corollas $8 \mathrm{~mm}$. long, a little exceeding the pappus, which is rather coarse ; mature akenes oblong, the apex truncate, nearly $2 \mathrm{~mm}$. long and one-fourth as broad, light brown, strongly ribbed, hispid.

Talca Chugiaguilla, I 890 (792). 
Senecio - Species apparently undescribed, but material insufficient. Vic. Cochabamba, I89 I (96I).

Barnadesia polyacantha, Wedd. Chlor. And. i. I3. Vic. La Paz, I $0,000 \mathrm{ft}$., I 890 (7 18 ).= Rusby I 552 and I 553.

Mutisia Orbignyana, Wedd. Chlor. And. i. 22. Vic. La Paz, Io, ooo ft., I 889 (68), and Talca Chugiaguilla, April, I890 (8I6). Also in Herb. Kew from La Paz by Pentland, fide Britton.

Mutisia viciafolia, Cav. Ic. v. 62, t. 490 (?). Vic. La. Paz, 10,000 ft. I 889 (78).=Mandon 7, not Matthew, Peru, 457. It seems pretty clear that two species have been confused under this name. Mandon No. 7 is referred by Schultz-Bipontinus to this species, but does not agree with the figure given by Lamarck, Ill., t. 690, Fig. 2. This figure agrees with the specimen of Matthews above mentioned and that of Ensign Safford from Chicla. Without reference to the original figure and description, or knowledge of the type, I cannot decide which specimens are correctly named.

Mutisia hastata, Cav. Ic. v. 64, t. 494, ex descr. Vic. Cochabamba, I 89 I (88I).

Mutisia Comptoniæfolia, sp. n. Shrub, the stem erect, much branched, the branches strongly ascending, densely leafy, glabrous; leaves 5-9 $\mathrm{cm}$. long, I 5-20 $\mathrm{mm}$. broad, narrowly lanceolate, the apex tapering but obtusish, the base tapering into a short, margined petiole, deeply pinnately-lobed, the divisions oblong-lanceolate, obtusish, serrulate, thickish, glabrous both sides; heads terminating the short leafy branchlets; involucre lanceolate-cylindrical, 3-4 $\mathrm{cm}$. long, $15 \mathrm{~mm}$. broad, glutinous, lanate, ovate, the outer scales acuminate and acute, the inner rounded; flowers exserted to the extent of $15 \mathrm{~mm}$.; rays few, narrow, scarlet.

Talca Chugiaguilla, April, I 890 (795).

Chuquiragua oppositifolia, Gill. et Don, Phil. Mag. I832, 392. Vic. La Paz, I0,000 ft., I 889 ( I 38).=Rusby I 555 and I 556.

Chuquiragua ferox (Wedd.) Britton, Bull. Torr. Bot. Club, xix. 266. Vic. La Paz, I0,000 ft., I 889 (96).= Rusby I 558.

more complete material even the genus cannot be certainly determined. Vic. La Paz, I0,000 ft., I 889 (66). Talca Chugiaguilla, April, I890 (79I). 
Thyrsanthema nutans (L.) Kuntze, Rev. Gen. Plant. 369. (Chaptalia mutans, Hemsley). Yungas, I 890 (237).

Proustia pungens, Poepp. in Less. Syn. I IO. Talca Chugiaguilla, April, 1890. Distributed as 797.

Perezia multiflora (H. \& B.) Less., Linnæa, I830, I 5. Vic. La Paz., I0,000 ft., I 890 (736). Also from Vic Cochabamba, I89I, without number (736a).

Perezia coenulescens, Wedd. Chlor. And. i. 39. Songo, Nov. I890 (9I 5). = Mandon 20.

Perezia Mandoni, sp. n. Radical leaves erect or strongly ascending, IO- $15 \mathrm{~cm}$. long, including the petiole, scarcely $\mathrm{I} \mathrm{cm}$. broad, linear-oblanceolate, sharply pointed, gradually tapering into the slender petiole, which is more than half as long as the blade, distantly sinuate-dentate, the teeth cuspidate, the midrib prominent both sides, below broad and channelled, both sides glabrous; stems several, slender, scapose, monocephalous. I-5 dm. long, many-bracted, the bracts 5-IO $\mathrm{mm}$. long, subulate with clasping base, acuminate, spinulose-dentate; involucre campanulate, about I $5 \mathrm{~mm}$. high, IO $\mathrm{mm}$. broad, pappus onefourth longer than the involucre, the scales lanceolate, acuminate and cuspidate, rigid, appressed, the outer successively shorter, the middle portion bright green, the broad margins white, scarious, the outer denticulate; receptacle slightly convex, foveolate; rays about $\mathrm{I} 5$, blue or bluish, oblong, the apex contracted, tridentate; disk-corollas $12 . \mathrm{mm}$. long, shorter than the tawny pappus; appendages of the anther black, $2 \mathrm{~mm}$. long, oblong obovoid, papillose.

Capi, March, I890, and Vic. Cochabamba, I 89I (777). = Mandon 24, fide Britton. Very distinct from P. pungens (H \& B.) Less., for which Mandon's specimens were distributed.

Jungia floribunda, Less. Linnæa, I830, 38. Yungas, I 890 (673). $=$ Rusby $\mathrm{I} 708$.

Hieracium BangiI, sp. n. Roots fibrous, densely fasciculate, the stem erect, stout, I meter or more high, hollow, angled, below densely hirsute with retrorse hairs, above more sparingly hirsute, the hairs born on a spiculiform base ; leaves $7-15 \mathrm{~cm}$. long, 3-6 $\mathrm{cm}$. broad, obovate or spatulate, the apex rounded but slightly mucronate, the base strongly clasping, thin and membranaceous, above sparsely strigose and minutely scabrous, underneath sparsely strigose, pale, with strong and coarse whitish midrib and veins; inflorescence loosely paniculate, the branches distant, elongated and weak, very sparingly bracted, the few heads irregularly crowded at the ends; involucre cam- 
panulate, $5 \mathrm{~mm}$. high, two-thirds as broad, with the border at length spreading, involucral scales linear-lanceolate, the outer shorter and broader, obtusish, thick, keeled, pubescent, the keel black-hispid; mature akenes $3 \mathrm{~mm}$. long, sub-cylindrical, the base narrowed, the apex truncate, ribbed, reddish-purple; pappus tawny, flexuous, rather coarse and sparse, longer than the akene.

Yungas, I 890 (27 I).

Hypochceris clata (Wedd.) Griseb. Symb. Fl. Arg. 218. Vic. La Paz, I0,000 ft., I 890 (I84). = Rusby I 723.

Hypocharis acaulis (Remy) Britton, Bull. Torr. Bot. Club, xix. 37 I. Vic. La Paz, I0,000 ft., I 890 (735). = Rusby I 7 I6.

Sonchus asper (L.) Vill. Fl. Delph. iii. I58. Vic. La Paz, I0,000 ft., I 889, (59). I 890 (I 5 I and I 82).

Picrosia longifolia Don, Trans. Linn. Soc. xvi. 183. Vic. Cochabamba, I 89 I (956). 





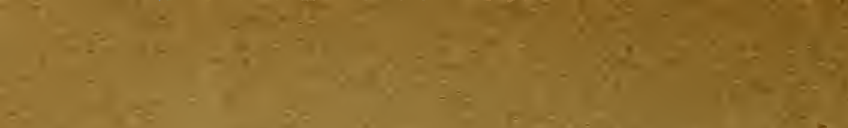

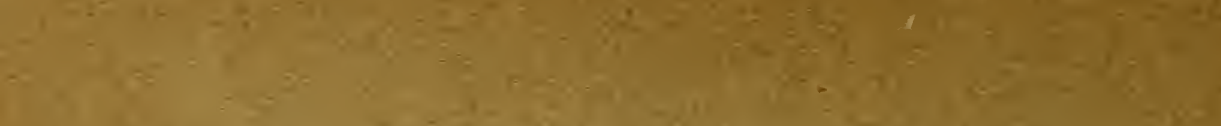

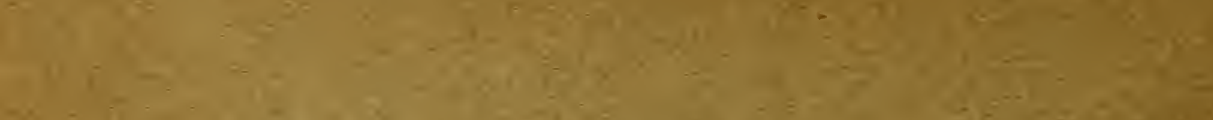

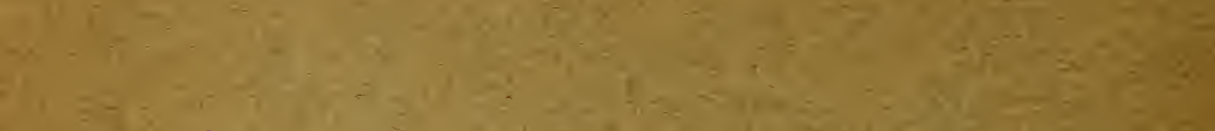

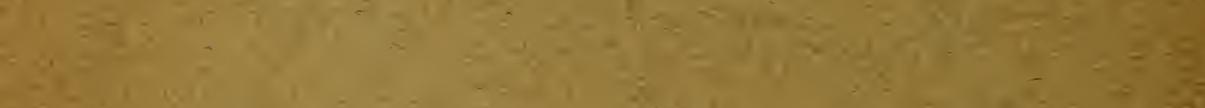

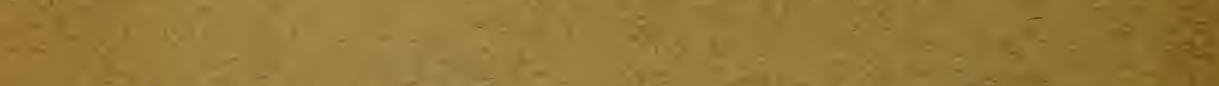

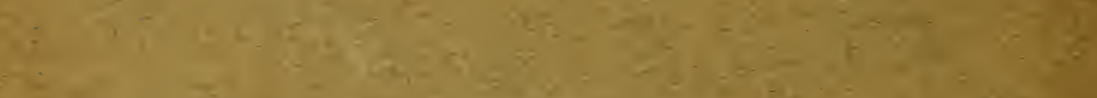

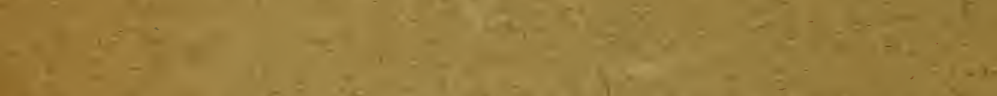

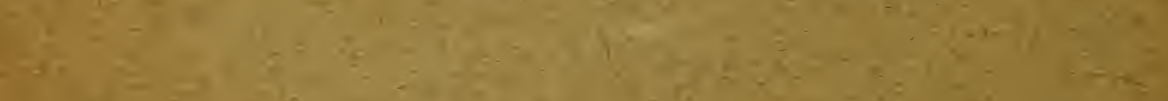

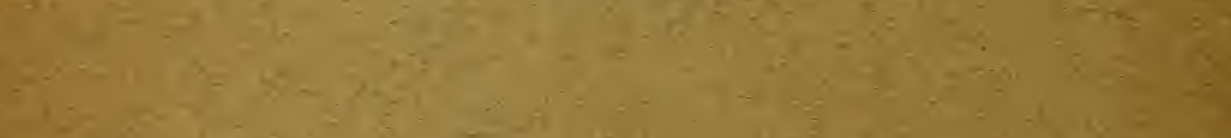

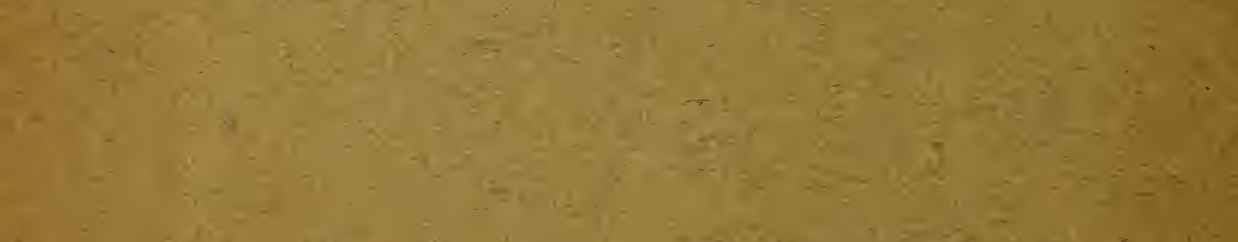

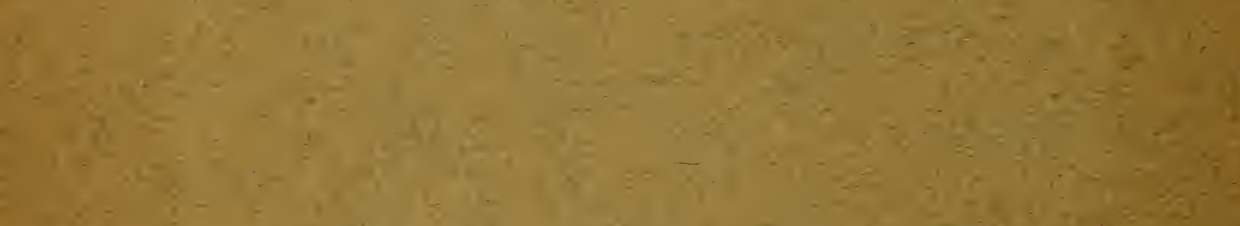

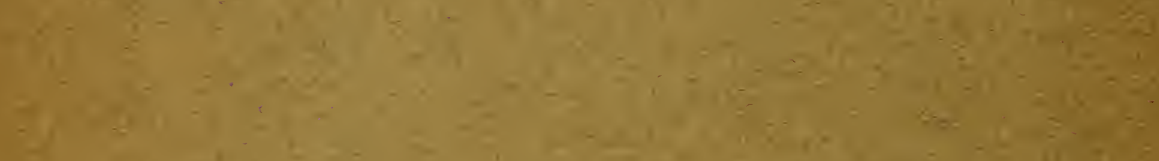

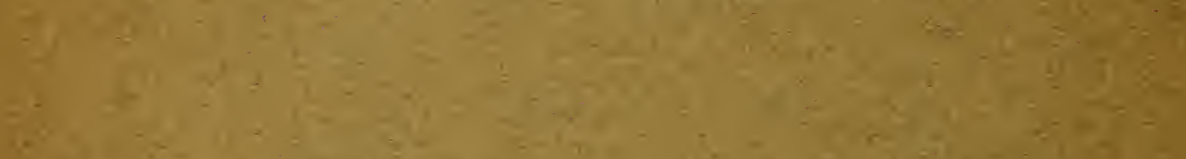

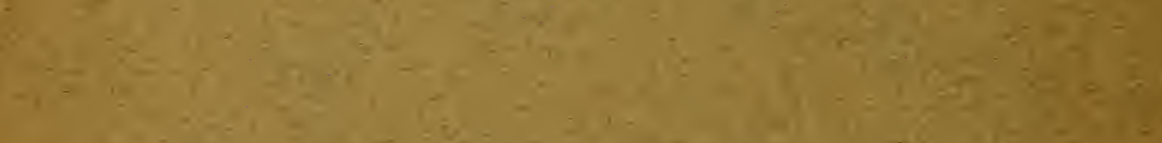

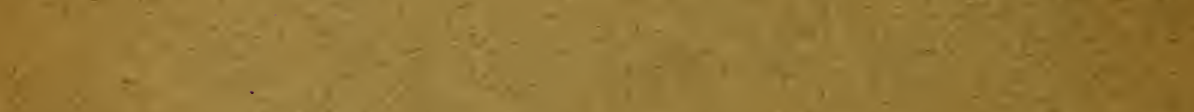

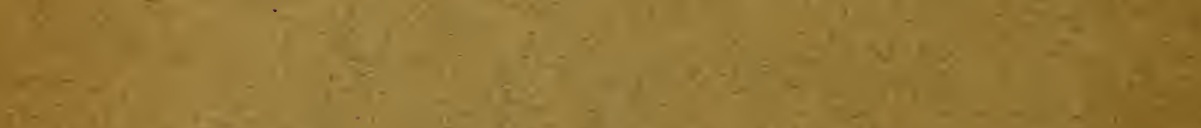

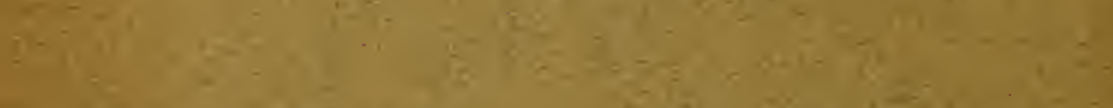

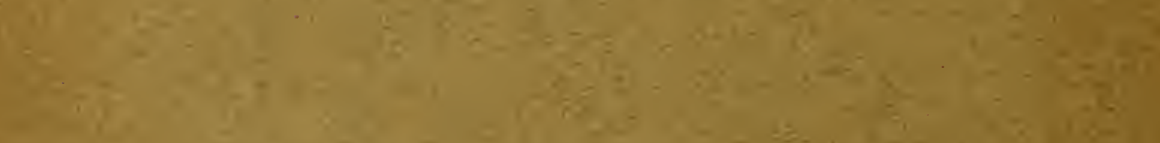

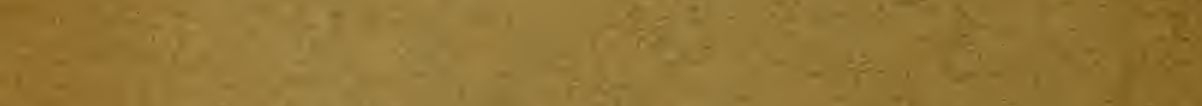

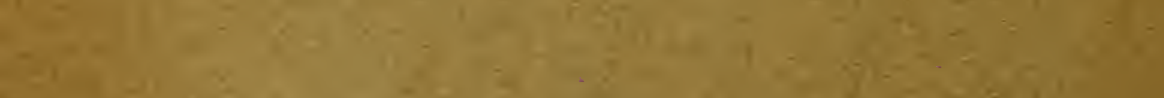

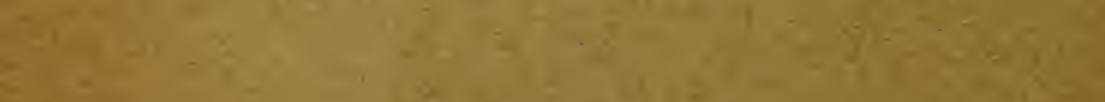

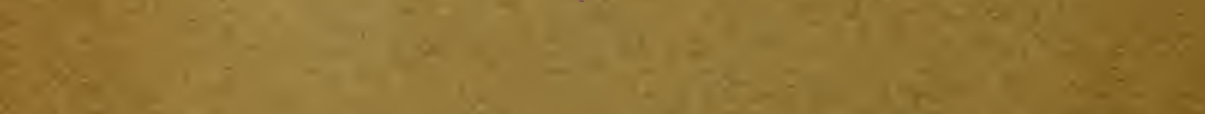

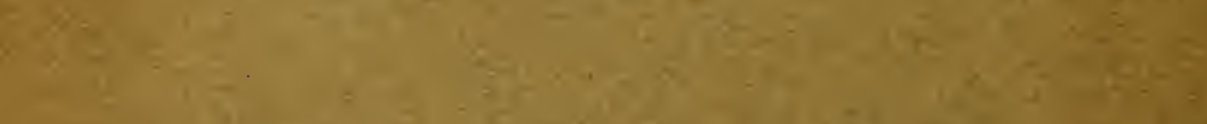

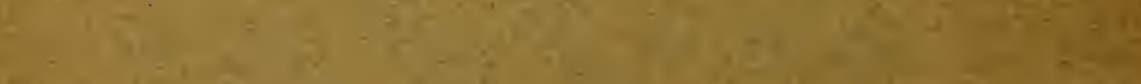

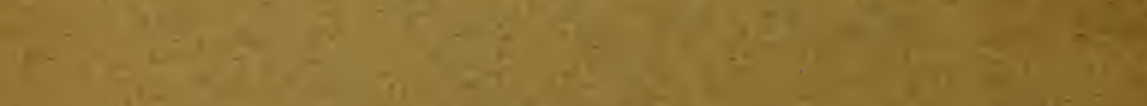

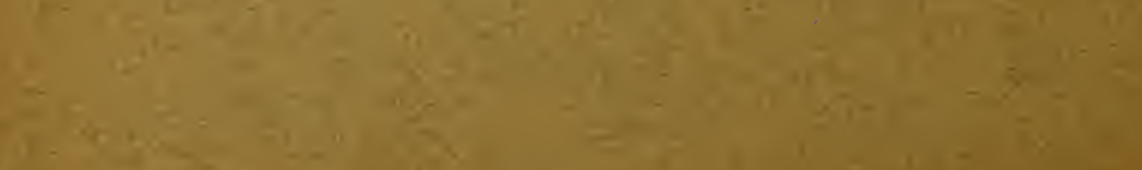

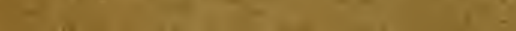
$y+3=y=0$ 


\section{4 क

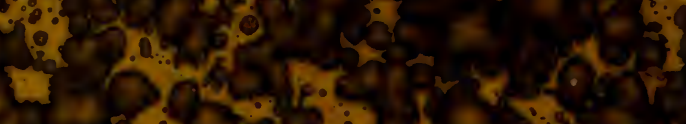

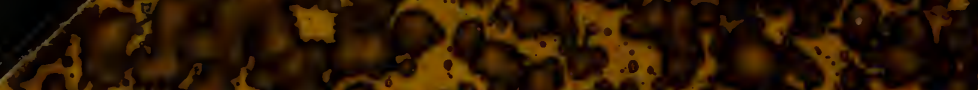

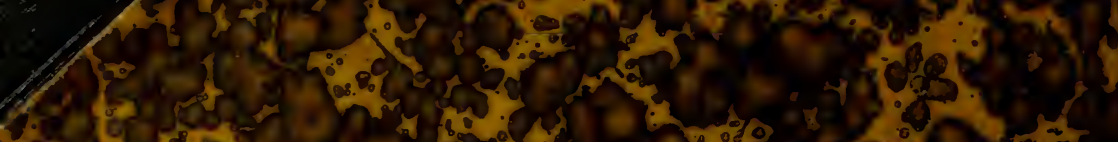

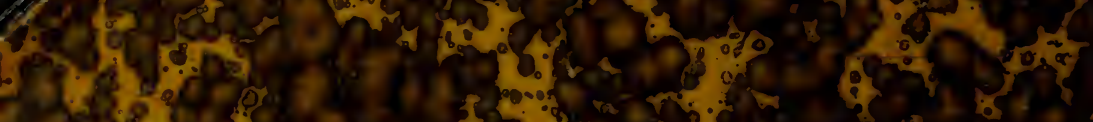

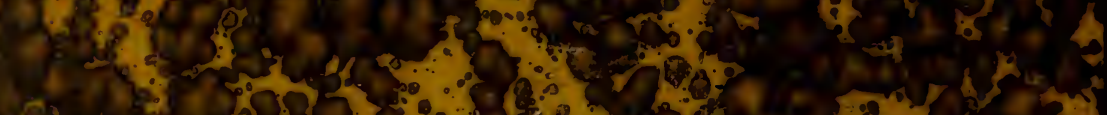

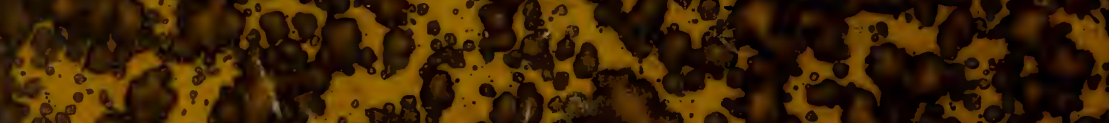
3.9 o.

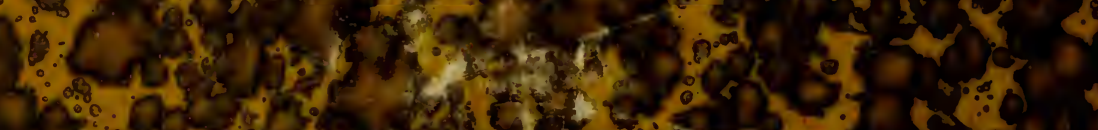
10.0. 16 a

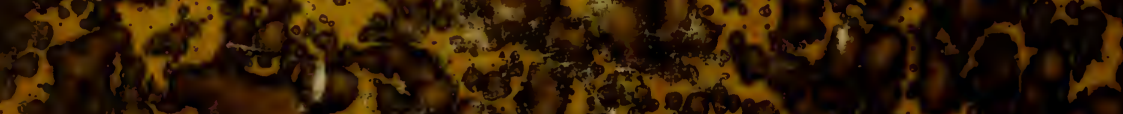
30457 a

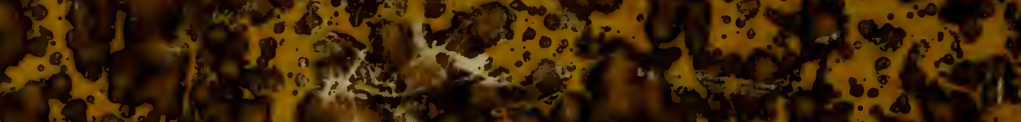
S.

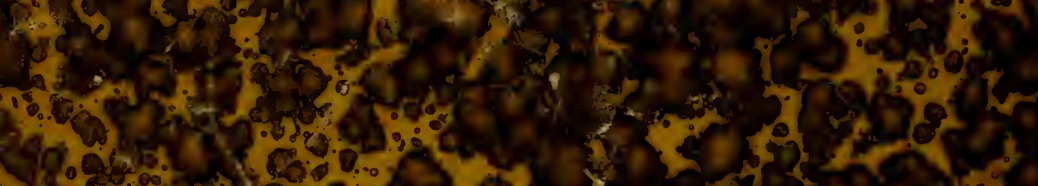
19.0.5.

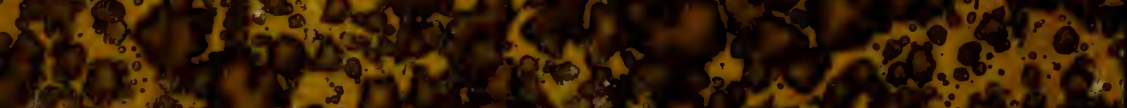
40.

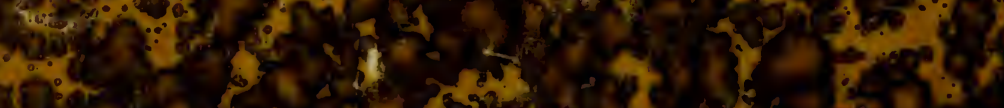
4.

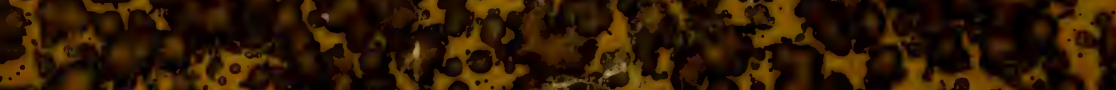

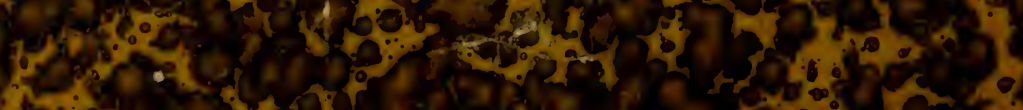

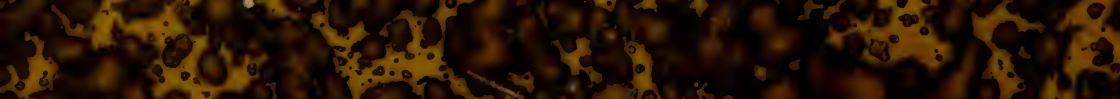

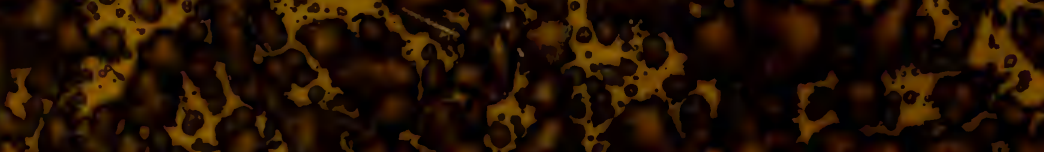

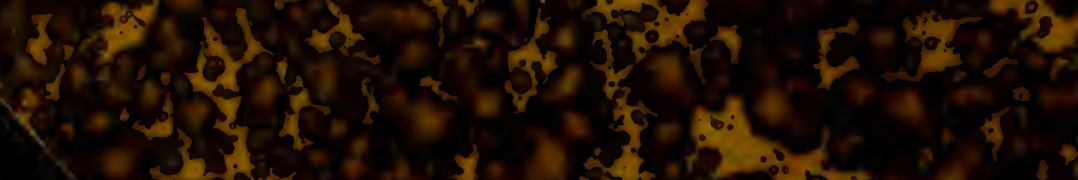

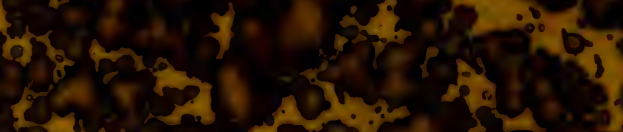

$$
\begin{aligned}
& \text { wh } \\
& \text { (5) }
\end{aligned}
$$

